\title{
Analysis and Development of an Online Knowledge Management Support System for a Community of Practice
}

by

\section{Moeketsi Mafereka}

BSc (BEng. Computer Systems and Networks)

A thesis submitted to the Department of Electrical Engineering,

University of Cape Town, in fulfilment of the requirements

for the degree of

Master of Science

at the

\section{UNIVERSITY OF CAPE TOWN}

Supervisor:

Dr. Simon Winberg

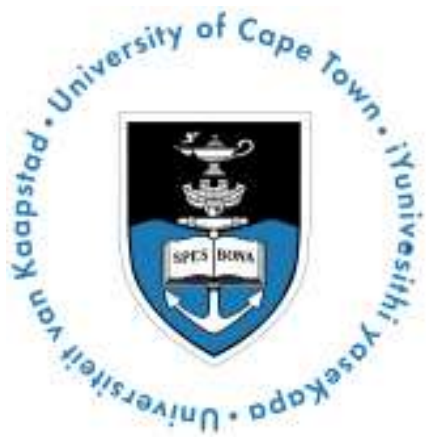

(C) University of Cape Town

April 2019 
The copyright of this thesis vests in the author. No quotation from it or information derived from it is to be published without full acknowledgement of the source. The thesis is to be used for private study or noncommercial research purposes only.

Published by the University of Cape Town (UCT) in terms of the non-exclusive license granted to UCT by the author. 


\section{Declaration}

I declare that this dissertation is my own, unaided work. It is being submitted for the degree of Master of Science in Engineering in the University of Cape Town. It has not been submitted before for any degree or examination in any other university.

Signature of Author:

Signed by candidate 


\section{Dedication}

I would like to dedicate this dissertation to Makabelo Mafereka (wife), Kabelo Mafereka (daughter) and Tlotliso Mafereka (son). 


\begin{abstract}
The purpose of this study was to investigate how particular business practices, focusing on those occurring in multi-site non-governmental organization (NGOs), could be enhanced by use of a knowledge management system (KMS). The main objective of this KMS is to enhance business processes and save costs for a multi-site NGO through streamlining the organizational practices of knowledge creation, storage, sharing and application. The methodology uses a multiple perspective approach, which covers exploration of the problem space and solution space. Under exploration of problem space, interviews with employees of the NGO are done to identify core problem that the organization faced. Still under exploration of problem space, organization's knowledge management maturity was assessed through an online questionnaire. The methodology then moved on to exploration of problem space. During the exploration of problem space, the requirements gathering and definition process was done through a combination of interviews with company employees and by completing a systematic literature review of best practices. The requirements were used to design system architecture and use-case models. The prototype for a Community of Practice (COP) support website was developed and investigated in test cases. The tests showed that the prototype system was able to facilitate asynchronous communication through the creation and management of events, creation and management of collaboration groups, creation of discussion topics and creation of basic pages. Furthermore, security capabilities were tested in terms of login functionality. Lastly page load times were tested for eight different scenarios. The system performance was found to be satisfactory because the scenarios covering crucial system requirements aspects had a response time of below 11 seconds. An exception was the landing page, which after login took 26 seconds to load. It is believed that creation of a platform that enables, and records, user interaction, easy of online discussions, managing groups, topics and events, are all major contributors to a successful knowledge management approach.
\end{abstract}




\section{Acknowledgements}

I would like to express my gratitude to the following people who assisted me during the course of this thesis.

Simon Winberg for his dedication and guidance as my Supervisor as I walked this journey.

Makabelo Mafereka (my wife), for her support through sleepless nights. 


\section{Nomenclature}

\begin{tabular}{|c|c|}
\hline ADP & Area Development Programme \\
\hline CHAT & Conversational Hypertext Access Technology \\
\hline CMMI & Capability Maturity Model Integrated \\
\hline CMS & Content Management System \\
\hline COP & Community of Practice \\
\hline DIR & Directory \\
\hline DME & Design Monitoring and Evaluation. \\
\hline HR & Human Resources \\
\hline HTML & Hypertext Mark-up Language \\
\hline KM & Knowledge Management \\
\hline KMS & Knowledge Management System \\
\hline Mafcop & Mafereka's Community of Practice \\
\hline NGO & Nongovernment Organization \\
\hline PEOU & Perceived Ease of use \\
\hline PHP & Hypertext Pre-processor \\
\hline PU & Perceived Usefulness \\
\hline RSS Feeds & Rich Site Summary \\
\hline SECI & $\begin{array}{l}\text { Socialization Externalization Combination and } \\
\text { Internalization Model. }\end{array}$ \\
\hline TAM & Technology Acceptance Model \\
\hline
\end{tabular}




\section{Contents}

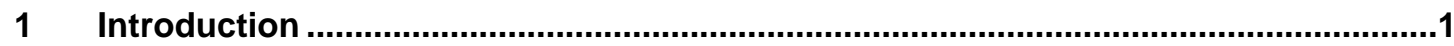

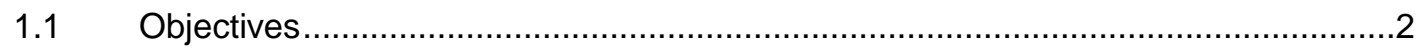

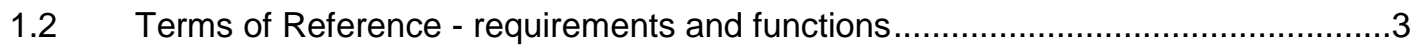

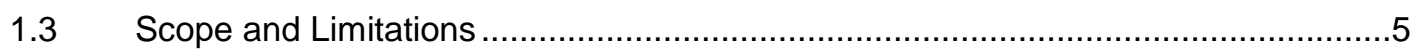

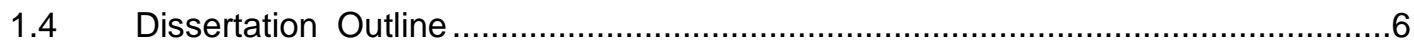

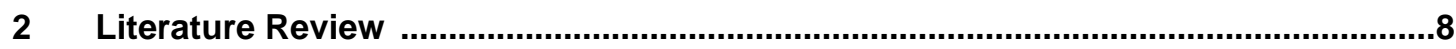

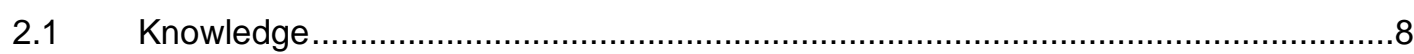

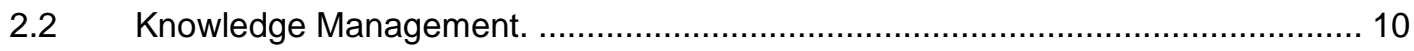

2.3 Knowledge Management System …….................................................... 10

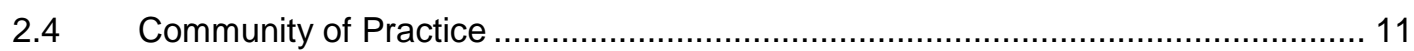

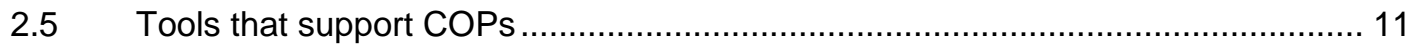

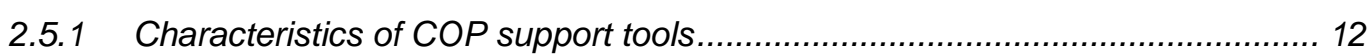

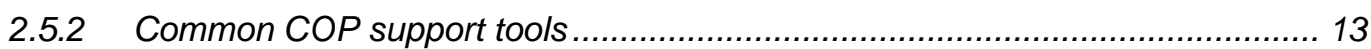

2.6 Challenges that organizations encounter with knowledge management............... 17

$2.7 \quad$ Knowledge management maturity assessment ................................................... 18

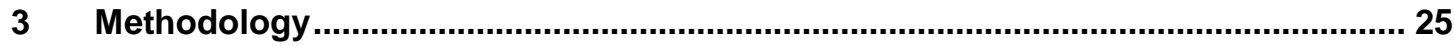

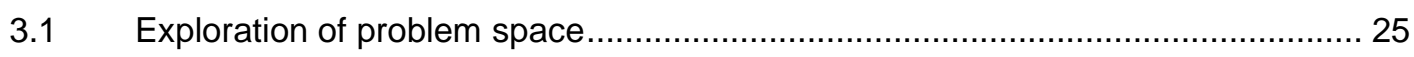

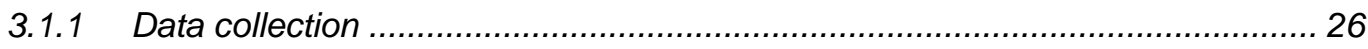

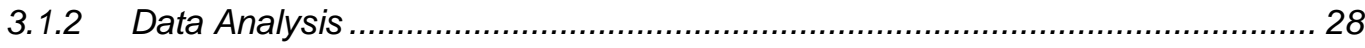

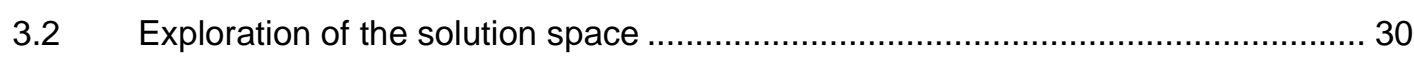

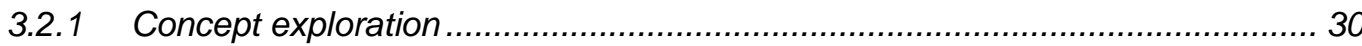

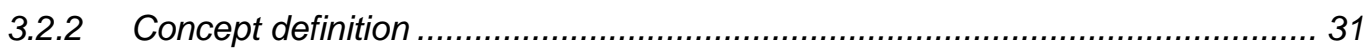

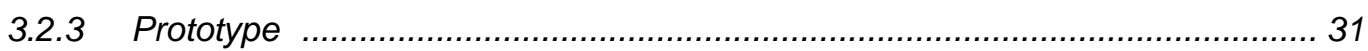

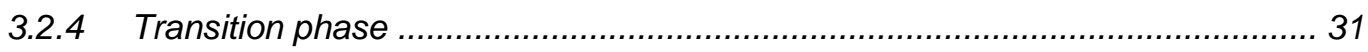

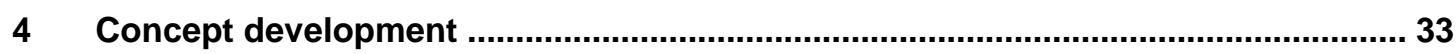

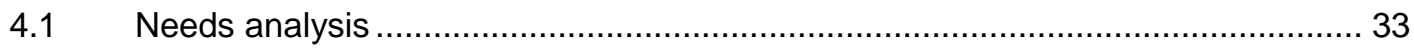

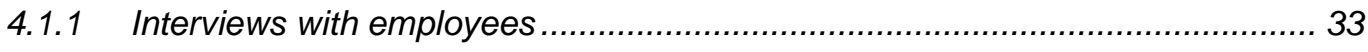

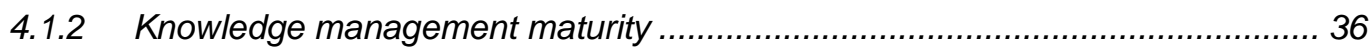

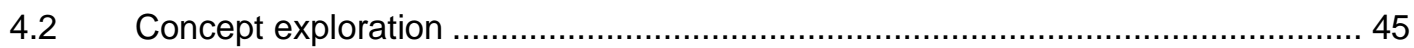

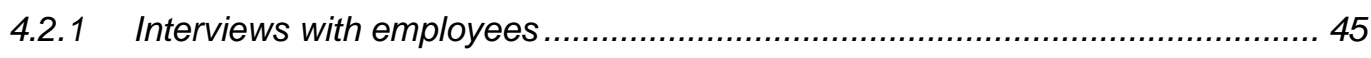

4.2.2 Requirements gathered from the literature ................................................ 47

4.2.3 Combination of requirements from interviews and literature ......................... 47

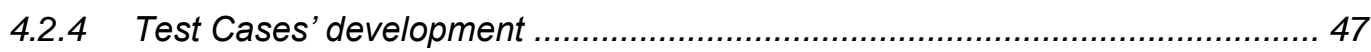

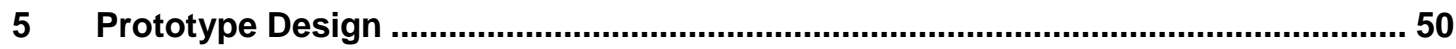

$5.1 \quad$ Layered architecture COP support website ……............................................... 50

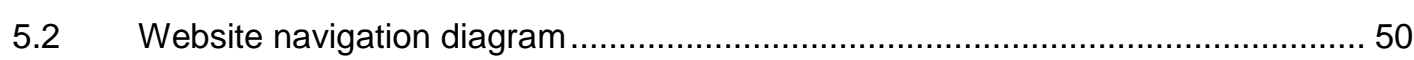

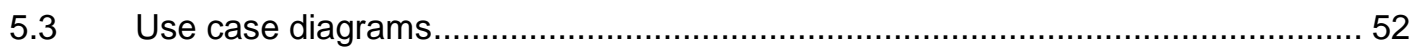




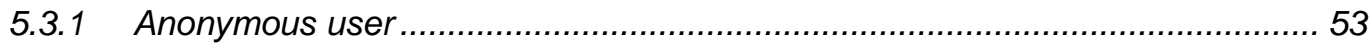

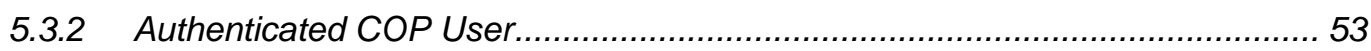

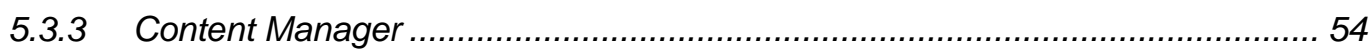

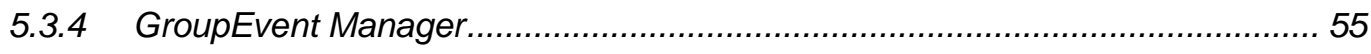

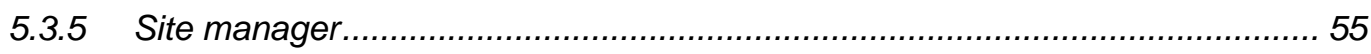

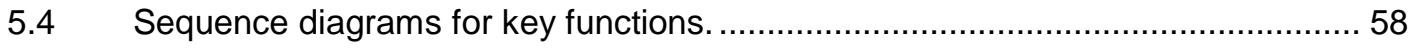

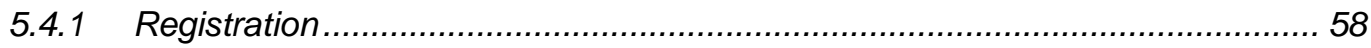

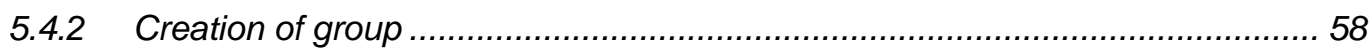

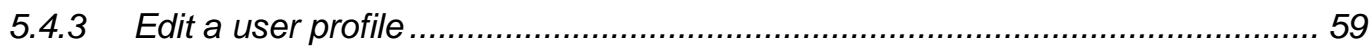

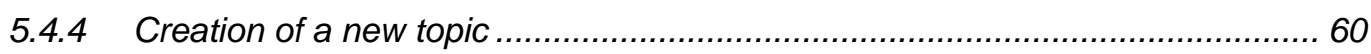

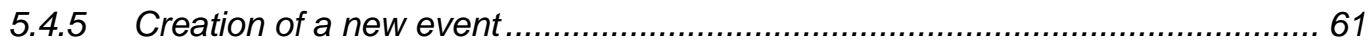

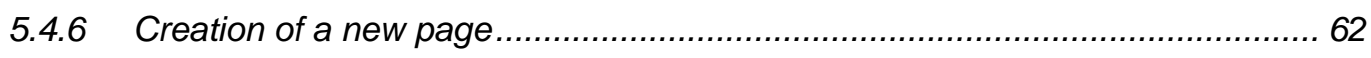

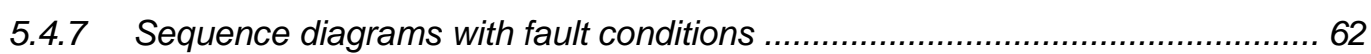

5.4.7.1 Sequence diagram invalid login into COP website .................................... 63

5.4.7.2 Sequence diagram for creating an event (date in the past) ........................ 63

5.4.7.3 Sequence diagram for uploading wrong image type ................................... 63

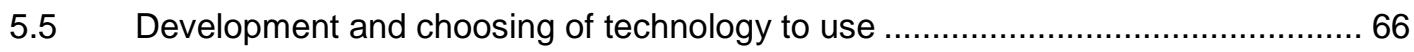

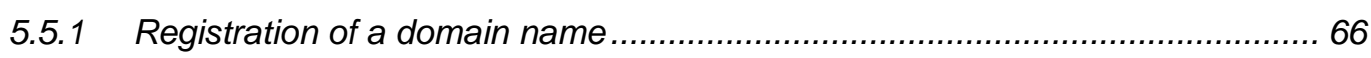

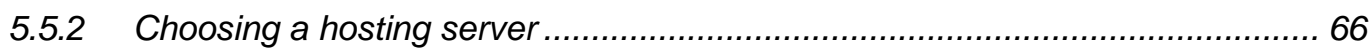

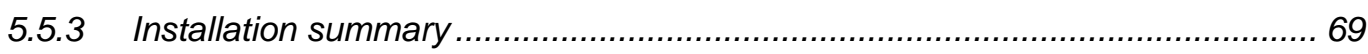

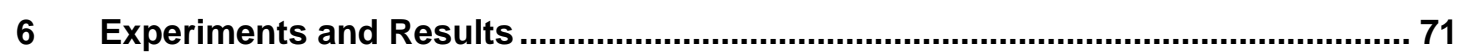

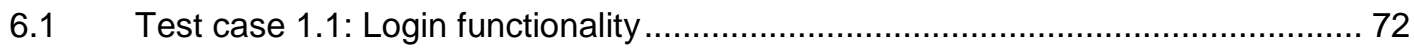

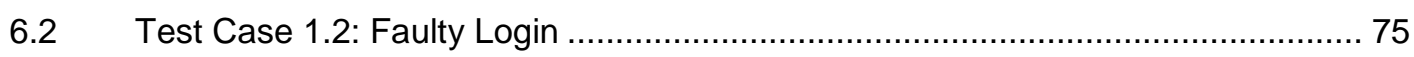

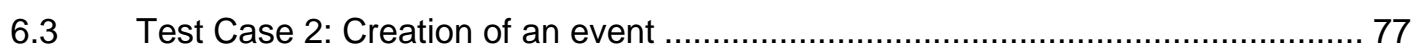

6.4 Test Case 2.1: Creation of an event (date in the past) ..................................... 78

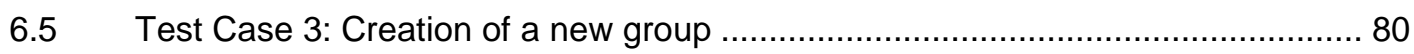

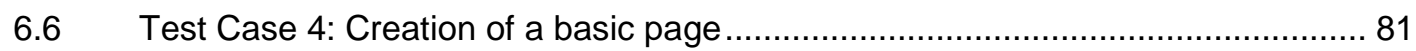

6.7 Test Case 4.1: Creation of a basic page (upload wrong image type) ................... 83

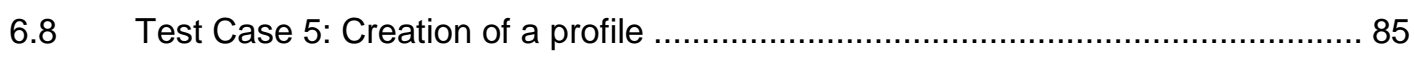

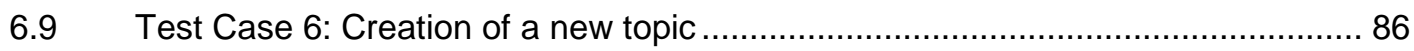

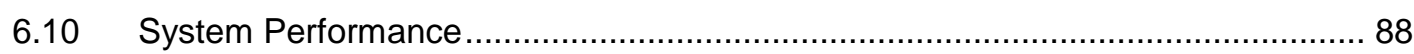

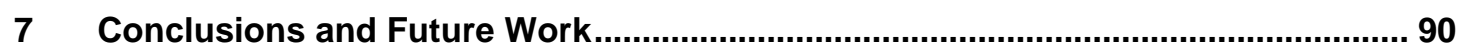

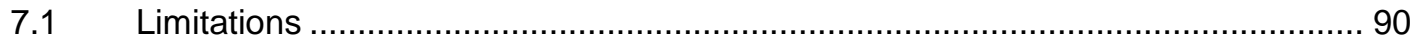

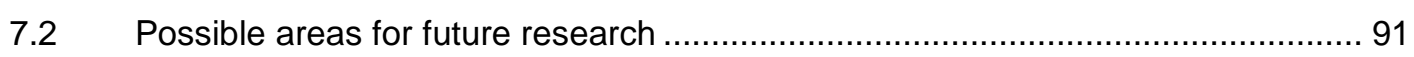

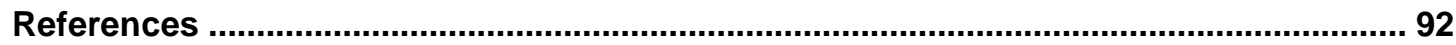

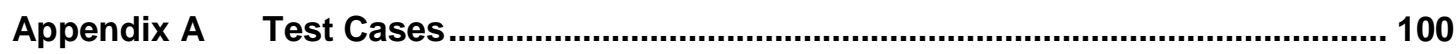

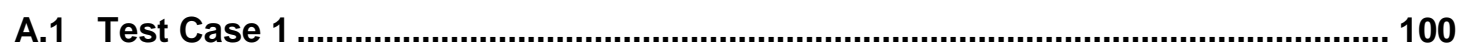

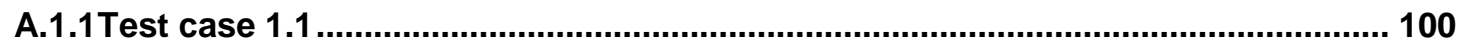

101 
A.1.2Test Case 1.2 103

A.2 Test Case 2

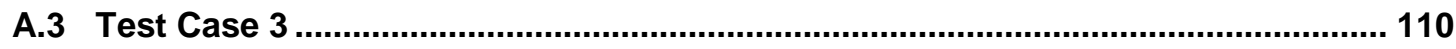

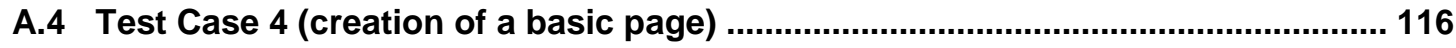

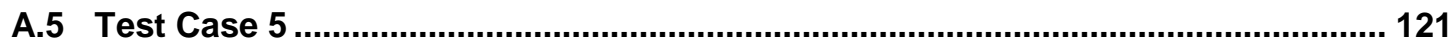

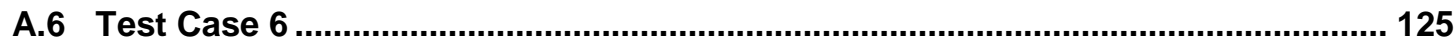




\section{List of Figures}

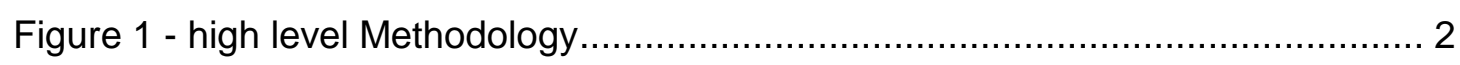

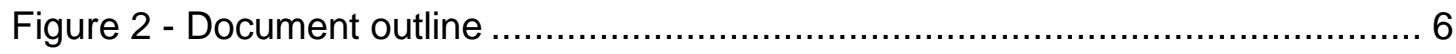

Figure 3 - The knowledge, information and data model hierarchy [16] ................... 9

Figure 4 - Model which clearly defines the difference between needs analysis, information audit and knowledge audit [24] ............................................. 19

Figure 5 - Research methodology followed in this project................................ 25

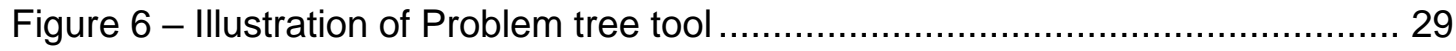

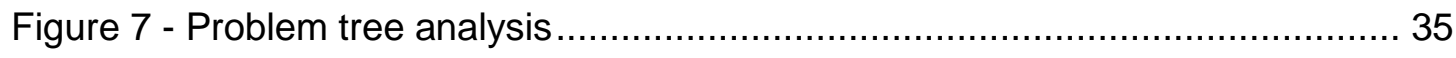

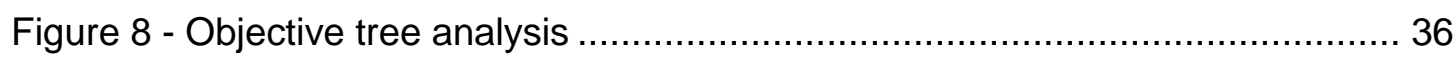

Figure 9 - Level of organized practice in knowledge management ....................... 37

Figure 10 - level of information system use for knowledge management................ 38

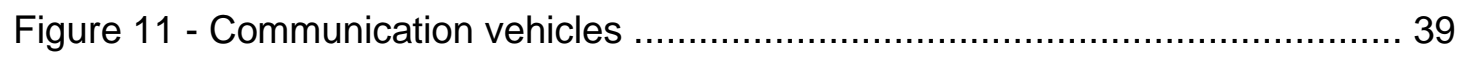

Figure 12 - sharing and storing policies, processes and procedures. .................... 39

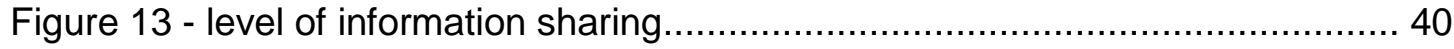

Figure 14 - Have any specialized IT resources or tools been developed - or under development - internally or by contract, to enhance KM practices in your organization? ........................................................................................ 40

Figure 15 - incentives for disseminating knowledge ....................................... 41

Figure 16 - employees' competence on knowledge management ........................ 41

Figure 17 - level of knowledge acquisition, storage and sharing with stakeholders.. 42 Figure 18 - sharing knowledge with beneficiaries. 
Figure 20 - COP Website navigation diagram (automatically generated from Drupal Mafcop website using Microsoft Visio) ....................................................... 52

Figure 21 - Use case for anonymous user ...................................................... 53

Figure 22 - Use Case diagram for a standard COP User................................... 54

Figure 24 - Group Event Manager ............................................................... 56

Figure 25 - Use case diagram for a Site Manager .......................................... 56

Figure 26 - Registration into COP website..................................................... 58

Figure 27 - Sequence diagram for creation of a new group in a COP Website ....... 59

Figure 28 - Sequence diagram for editing of a user profile................................6 60

Figure 29 - Sequence diagram for creation of a new topic................................. 61

Figure 30 - Sequence diagram for creation of a new event................................ 61

Figure 31 - Sequence diagram for creating a new page.................................... 62

Figure 32 - sequence diagram for invalid login into COP website ........................6 63

Figure 33 - sequence diagram for creation of an event (event date in the past)...... 64

Figure 34 - Sequence diagram for creation of a new page (wrong image type) ....... 64

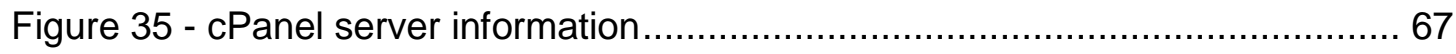

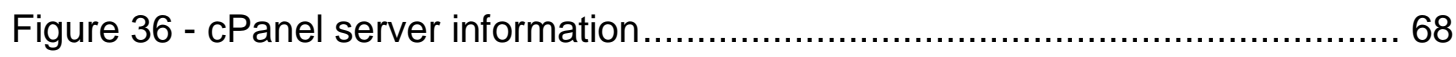

Figure 37 - Open Social installation process (note that both top and bottom flow charts can run simultaneously)............................................................... 70

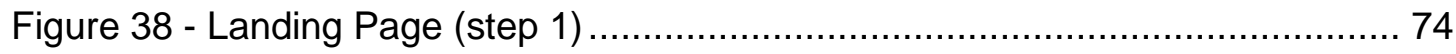

Figure 39 - login screen for entering security credentials................................ 74

Figure 40 - Landing page after entering correct password.................................... 75

Figure 41 - Error Message after entering incorrect password (Step 3).................... 76 


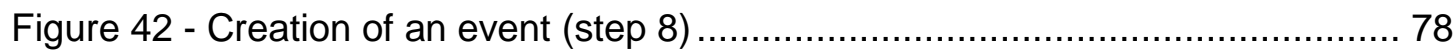

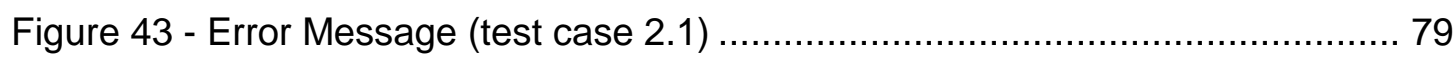

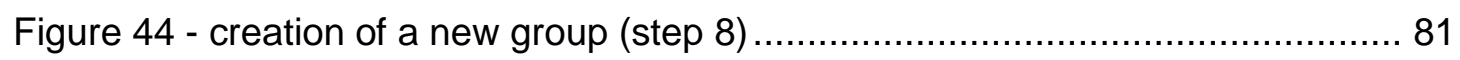

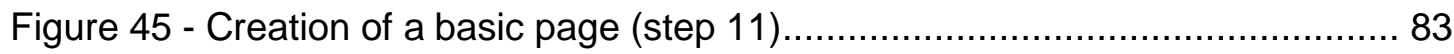

Figure 46 - test case 4.1 (uploading wrong image file) .................................... 84

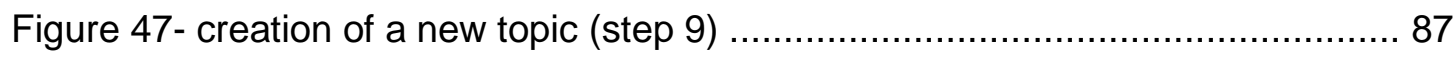

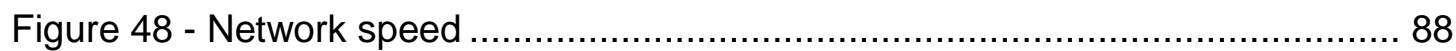

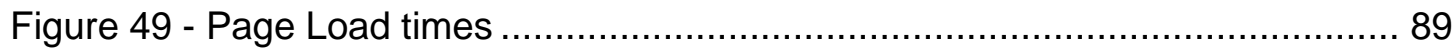




\section{List of Tables}

Table 1.1: Breakdown of sub-tests to be performed in the testing process. .............................

Table 1.2: Tools that support COPs [20] .................................................................... 13

Table 1.3: - Jochem, Geers and Hainze's knowledge management maturity model [25] ....... 20

Table 1.4: Islam, Walton, Egbu and Gupta's Knowledge management maturity model [26] .. 21

Table 1.5: Olivia's Knowledge Management Maturity Model [27] ........................................ 21

Table 1.6: Khatibian, Hasan, and Jafari's Knowledge Management Maturity model [28] ....... 22

Table 1.7: Requirements gathering- interviews with employees ........................................... 45

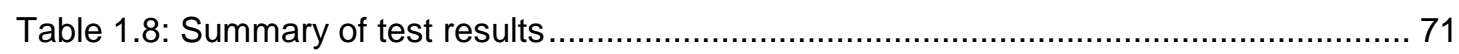

Table 1.9: Report for Test Case 1.1 - Login Functionality ................................................. 73

Table 1.10: Test Case 1.2 results (login functionality) ........................................................... 76

Table 1.11: Test Case 2 results (Creation of an event) .................................................... 77

Table 1.12: Creation of an event (date in the past) ........................................................... 78

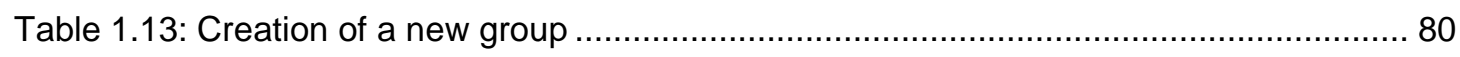

Table 1.14: Table 2 - Creation of a basic page .............................................................. 82

Table 1.15: Test case 4.1 uploading wrong image type ...................................................... 83

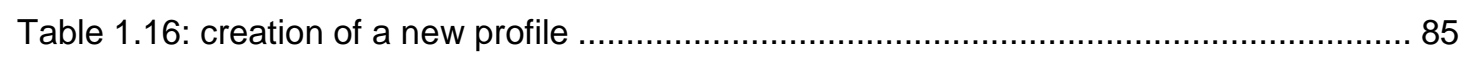

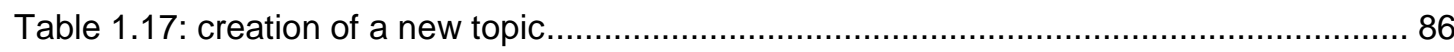




\section{Introduction}

Organizations design and implement their operational strategies in line with their vision and mission [1]. These strategies are then cascaded to the employees to be carried out.. Failure - or success - of such projects is dependent on many factors; a significant one of which is how effective the organization is in terms of managing its knowledge. [2] For example, does the organization have documentation of lessons learnt, where employees can refer to previous projects for tactics that influenced its success? Furthermore, the projects carried out at a company often fall into to broad categogies: the type are project that are more closely aligned to implementing operational strategies of the organization, commonly called flagship projects or strategic projects; but the are often, in addition to these, multiple 'business as usual' type activities that are referred to as operational activities in this dissertation. These are activities that are important for day-to-day running of an organization, and for the activities carried out in these projects there may be less emphasis in these being carried out in a way that demonstrates the company's vision and mission in a more externally visible manner. [3] Such activities are dependent on the documented process and, very importantly, the skills and competencies of employees that are performing these activities. In most organizations, when one employee leaves an organization it takes a lot of time to trainup a new recruit to replace the departing employee, especially if there are no documented processes and procedures that can be used, either by the trainer or the new recruit, during this process process. The know-how is in the minds of the employees doing the jobs. The reason why this is the case is because most organizations have ad-hoc knowledge management practices. The problem statement for this research is that most multi-site organizations struggle to reach their strategic goals because they possess inefficient and adhoc knowledge management practices and do not have platforms that enable their employees to discover, capture, share and apply knowledge. This research is aimed at investigating the core problems that the organization is faced with in terms of knowledge management, assess its knowledge management maturity, identify gaps and gather requirements, then move on to explore the concept by developing the system architecture and finalise by developing and testing the prototype.

The Methodology that was followed throughout this research project is portrayed by Figure 1. The Thesis is also structured in line with this methodology which spans needs 
analysis, concept exploration, concept definition and lastly prototype development and testing. [4] [5]

The next sections of the introduction cover objectives of the research, terms of reference, scope and limitations, and document outline.

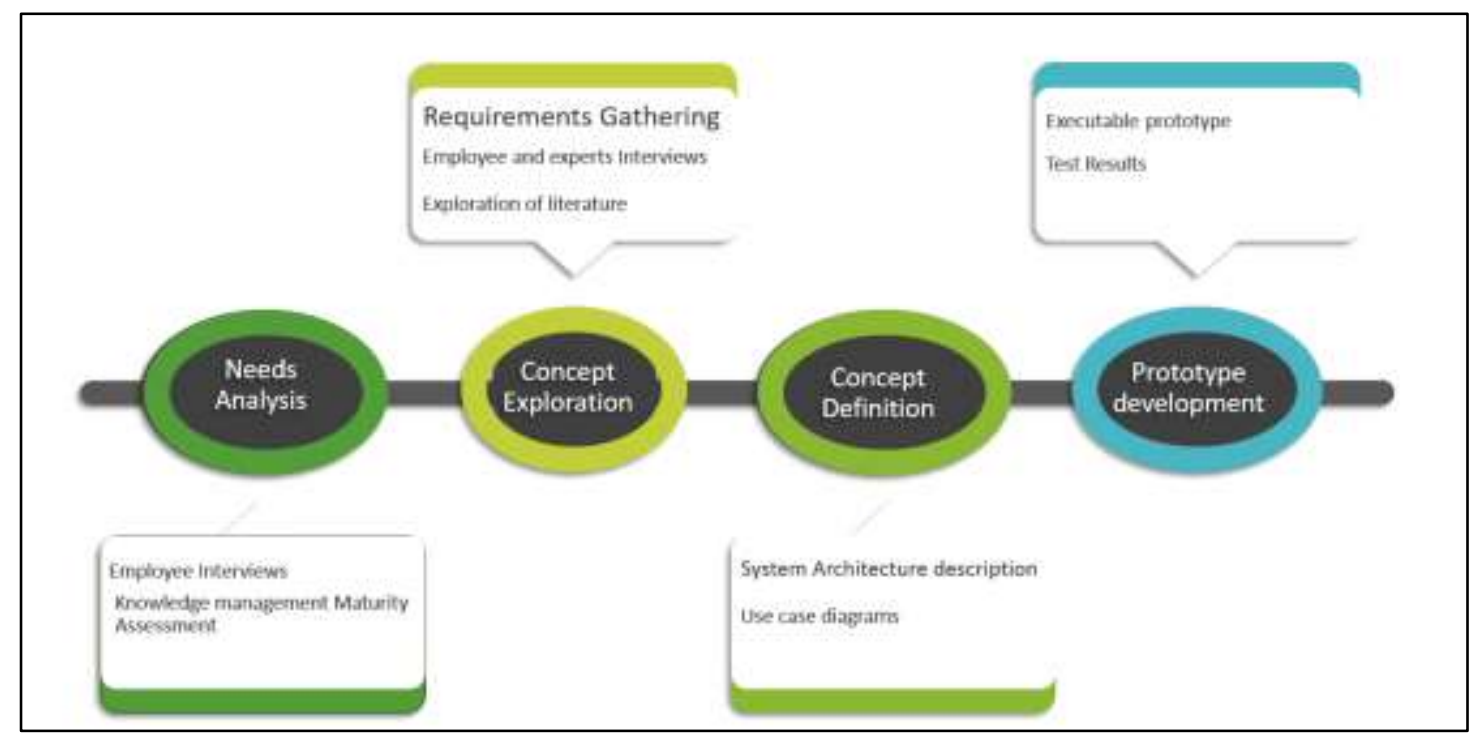

\section{Figure 1 - high level Methodology}

\subsection{Objectives}

The research project focuses on enhancing business processes using a knowledge management system. Below are the broad objectives set out to be achieved in this research project:

i) Identify the core problem with respect to knowledge management.

ii) Come up with the Solution to the core problem with respect to knowledge management.

iii) Design the Solution Prototype.

iv) Develop and test a solution prototype.

v) Use parts of the Rational unified Process, Prince 2, Systems engineering and software engineering techniques in implementing a design according to the above solution plan. 


\subsection{Terms of Reference - requirements and functions}

Objective ii) above focuses on exploring the solution to the core problem. The COP support system was selected as the solution that can solve the core problem identified in the Needs Analysis Stage of the Methodology. Requirements were gathered from the literature and further details are expounded under Chapter 2. The requirements from the literature were combined with those gathered through interviewing employees of the company used in the case study, and a follow up interview with an experienced software developer to gain an in-depth second perspective on the proposed design was done. Such requirements are elaborated further in chapter 4 under section 4.2.1.

Below is the summary of the main requirements of the COP system prototype:

R1. Facilitate asynchronous communication [13][12][14]

R2. Facilitate synchronous communication.[7][14][15]

R3. RSS Feeds.[12][16]

R4. Customizable.[12][14][17][15][18]

R5. Easily navigated and searched.[12][16][18]19

The functionality needed to achieve these requirements:

F1. Asynchronous communication: The system shall facilitate communication through discussion forums. Furthermore, the system should facilitate communication of community events.

F2. Synchronous communication: COP members shall be able to communicate in real time using CHAT functionality.

F3. Uploading of files: The system shall have a capability of uploading and sharing of different files.

F4. Tagging: Content tagging to improve search ability.

F5. Groups: Configuration and creation of collaboration groups

F6. RSS Feeds: Capability to create RSS feeds.

F7. Profile: A COP member shall be able to create and maintain his or her own profile.

F8. The pages should take 10 seconds or less to load. 
Test results are summarised by Table 1.1 below.

Table 1.1: Breakdown of sub-tests to be performed in the testing process.

\begin{tabular}{|c|c|c|c|}
\hline $\begin{array}{l}\text { Test } \\
\text { Number }\end{array}$ & Description & Functions Checked & Requirements Tested \\
\hline $\begin{array}{l}\text { Test } \\
\text { Case } 1.1\end{array}$ & Login Functionality & $\begin{array}{l}\text { Test the Login functionality } \\
\text { of the COP website using } \\
\text { correct login credentials. }\end{array}$ & Security. \\
\hline $\begin{array}{l}\text { Test } \\
\text { Case } 1.2\end{array}$ & Login Functionality & $\begin{array}{l}\text { Test the Login functionality } \\
\text { of the COP website using } \\
\text { incorrect login credentials. }\end{array}$ & Security. \\
\hline $\begin{array}{l}\text { Test } \\
\text { Case } 2\end{array}$ & $\begin{array}{l}\text { Creation of an } \\
\text { event }\end{array}$ & $\begin{array}{l}\text { Creation of an event } \\
\text { functionality in the COP } \\
\text { website. }\end{array}$ & R1. \\
\hline $\begin{array}{l}\text { Test } \\
\text { Case } 2.1\end{array}$ & $\begin{array}{l}\text { Creation of an } \\
\text { event (date in the } \\
\text { past) }\end{array}$ & $\begin{array}{l}\text { Creation of an event } \\
\text { functionality in the COP } \\
\text { website. (date in the past) }\end{array}$ & $\begin{array}{l}\text { R1. Fault condition: setting } \\
\text { an event in the past }\end{array}$ \\
\hline $\begin{array}{l}\text { Test } \\
\text { Case } 3\end{array}$ & Creation of a group & $\begin{array}{l}\text { Test creation of a group in } \\
\text { the COP website }\end{array}$ & $\begin{array}{l}\text { R1. Groups: Configuration } \\
\text { and creation of collaboration } \\
\text { groups }\end{array}$ \\
\hline $\begin{array}{l}\text { Test } \\
\text { Case } 4\end{array}$ & $\begin{array}{l}\text { Creation of a basic } \\
\text { page }\end{array}$ & $\begin{array}{l}\text { Test creation of a basic } \\
\text { page }\end{array}$ & $\begin{array}{l}\text { R1. Asynchronous } \\
\text { communication. }\end{array}$ \\
\hline $\begin{array}{l}\text { Test } \\
\text { Case } 4.1\end{array}$ & $\begin{array}{l}\text { Creation of a basic } \\
\text { page (upload } \\
\text { wrong image type) }\end{array}$ & $\begin{array}{l}\text { Test creation of a basic } \\
\text { page (upload wrong image } \\
\text { type) }\end{array}$ & $\begin{array}{l}\text { R1. Fault condition: } \\
\text { uploading wrong image } \\
\text { type. }\end{array}$ \\
\hline $\begin{array}{l}\text { Test } \\
\text { Case } 5\end{array}$ & Creation of a profile & Test creation of a profile & $\begin{array}{l}\text { R4. Profile: A COP member } \\
\text { shall be able to create and } \\
\text { maintain his or her own } \\
\text { profile. }\end{array}$ \\
\hline $\begin{array}{l}\text { Test } \\
\text { Case } 6\end{array}$ & $\begin{array}{l}\text { Creation of a new } \\
\text { topic }\end{array}$ & $\begin{array}{l}\text { Test creation of a new } \\
\text { topic }\end{array}$ & $\begin{array}{l}\text { R1. Asynchronous } \\
\text { communication. }\end{array}$ \\
\hline
\end{tabular}




\begin{tabular}{|l|l|lr|l|}
\hline $\begin{array}{l}\text { Test } \\
\text { Case 7 }\end{array}$ & CHAT functionality & $\begin{array}{l}\text { Test real time } \\
\text { communication using } \\
\text { CHAT }\end{array}$ & $\begin{array}{l}\text { R2. } \\
\text { communication. }\end{array}$ \\
\hline $\begin{array}{l}\text { Test } \\
\text { Case 8 }\end{array}$ & RSS Feeds & Test RSS Feeds & R3. RSS Feeds. \\
\hline $\begin{array}{l}\text { Test } \\
\text { Case 9 }\end{array}$ & $\begin{array}{l}\text { Pages Loading } \\
\text { time }\end{array}$ & $\begin{array}{l}\text { How long pages take to } \\
\text { load }\end{array}$ & Pages loading time. \\
\hline
\end{tabular}

\subsection{Scope and Limitations}

This section describes the scope of the research project and its limitations.

The research project starts by exploration of problem space phase where interviews with employees to find out existing problems relating to knowledge management within the organization were completed successfully. Furthermore, measurement of the Knowledge Management Maturity was done through an online questionnaire. In the Elaboration Phase, user and system requirements were gathered and defined through exploration of literature and interviews of employees and industry experts. System architecture and use case models were also developed out of user and system requirements. Prototype was developed and tested successfully. Test cases 1 to 6 were executed successfully. Furthermore, Test Case 9 was executed successfully to measure how long pages take to load. However, due to time constraints, the tests for pages loading times were done with two simultaneous users. Test Case 7 and 8 were not executed because the functionality was not yet developed in the prototype due to time constraints. Due to time limitation the COP website was not piloted in the organization under this study.

\subsection{Significance of the study}

This research study will benefit organizations, mostly multi-site oriented ones that are in the journey to implement knowledge management systems. The study has explored the literature deeply to unearth key requirements that can be considered to make a knowledge management system (KMS) a success. Furthermore, it covered different methodologies that can be used to assess knowledge management maturity of an organization. Also, different knowledge management tools were explored and this can 
guide anyone who is in the process of selecting a knowledge management tool. The study added into the literature content on comparison of three popular and open source Content Management Systems (CMS) namely Joomla, WordPress and Drupal with regard to development of Community of Practice Website [6]. The usage of these CMS(s) can benefit multi-site NGOs in implementing a KMS as they can be used free of charge. Last but not least, this research study will help organizations or individuals working on knowledge management system project in terms of system design through re-using or rebuilding study's prototype designs when creating their KMS designs.

\subsection{Dissertation Outline}

In this section, the structure and sequencing with a summary reflecting on the main aspects of each chapter are defined. Pictorial illustration of this is shown by Figure 2 .

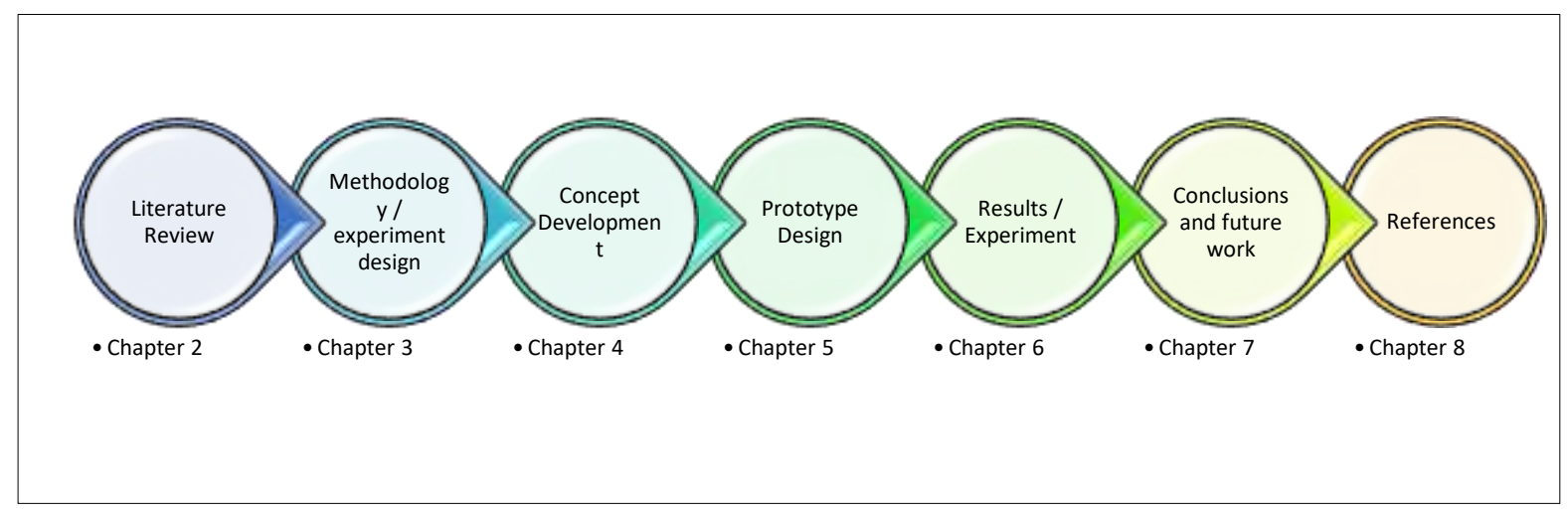

\section{Figure 2 - Document outline}

Literature review is covered under Chapter 2. It presents technologies, theories and techniques on which this thesis builds. It also covers definitions of knowledge, knowledge management and knowledge management systems. Also, it comprises of a deep dive into community of practice (COP), requirements and tools that support COPs. Challenges that organizations encounter with regard to knowledge management are also discussed. Lastly, knowledge management maturity is explored including knowledge management maturity assessments.

Chapter 3 presents the research methodology followed in this research project. Methodology touches on exploration of the problem space in terms of how needs analysis was carried out. It goes on to explain in depth the elaboration phase which entails concept exploration and concept definition. Furthermore, it explores prototype development and testing. 
Chapter 4 covers concept development. It covers needs analysis and it is more on exploration of the problem space in system design terms. Under needs analysis interviews with employees of the organization under this study were conducted to understand some of the problems that are faced by this organization. Furthermore, an online survey was designed as a way to gauge the organizations level of maturity with regard to knowledge management. Also, it touches on concept exploration whereby requirements were gathered through exploration of literature and interviews with users.

Chapter 5 is Prototype design. It is all about designs of the prototype using requirements gathered in Chapter 4 . These include layered architecture, website navigation diagram, key use case diagrams, and sequence diagrams for key functions. Development of the prototype based on the designs is also part of this chapter.

Chapter 6 presents the results, showing results of the design or system in action, and results of the tests that were carried out in the stages of the acceptance tests.

Chapter 7 provides the conclusions preceded by a discussion summarizing the highlights of the project and the findings. Additionally, it also covers limitations that were found related to ways tests were done followed by a more generalized discussion and conclusions. Moreover, future work plans and suggestions are touched.

The references are provided after the last chapter. 


\section{Literature Review}

This chapter covers the definition of knowledge, knowledge management, and knowledge management systems. It furthers defines the concept of a community of practice (COP), their importance to knowledge management, and tools that support COPs. Furthermore, it touches on challenges that organizations encounter with regard to knowledge management. Finally, it expounds on different knowledge management maturity methodologies, which are used further in the evaluation part of this dissertation.

\subsection{Knowledge}

There are different definitions of knowledge and knowledge management in the literature. Knowledge can be considered a "justified personal belief" [7], in that it exists in the mind of an individual. Davenport and Prusak [8] posit that knowledge is a fluid mix of framed experience, values, contextual information, and expert insight that provides a framework for evaluating and incorporating new experiences and information. It originates and is applied in the minds of 'knowers'. In organizations, it often becomes embedded not only in documents or repositories but also in organizational routines, processes, practices, and norms [8]. Becerra-Fernandez and Sabherwal [9] note that knowledge consists of truths and beliefs, perspectives and concepts, judgments and expectations, methodologies, and know-how. Tsoukas and Vladimirou [10] make a distinction between individual and organizational knowledge. They describe individual knowledge as a capability to draw distinctions within a domain of action, based on appreciation of context or theory or both. Their definition of organizational knowledge is a capability members of an organization have developed to draw distinctions in the process of carrying out their work, in particular concrete contexts by matching sets of generalization. According to Pritchard [11], there are two types of knowledge being propositional and ability knowledge. Propositional knowledge is what is asserted by a sentence which says that something is the case, for an example, the earth is flat whilst ability knowledge is the know-how, that is, the ability to do certain tasks or functions for example riding a bicycle. Nonaka and Konno [12] posit that there are two kinds of knowledge being explicit and tacit knowledge. Explicit knowledge can be expresses in words and numbers and shared in the form of data, scientific formulae, specifications, manuals and the like. Tacit knowledge is highly personal and hard to formalize, it is deeply rooted in an individual's actions and experience as well as in the ideals, values, or emotions he or she embraces. Other 
scholars have resorted to alternative formulations, for example Hildreth [13] differentiated between hard and soft knowledge; hard knowledge being the knowledge that can be easily articulated while soft knowledge is not so easily articulated and cannot be readily captured. Hara [14] in her study of two communities of practice in involving public defenders has offered another model made up of book knowledge, practical knowledge and cultural knowledge. In her formulation, book knowledge refers to an individual's awareness of knowledge about mere facts such as statutes, policies and standards. Practical knowledge implies book knowledge applied to practice and this includes the know-how and this definition is similar to ability knowledge as described by Pritchard [11]. Cultural knowledge includes both ones belief toward a practice as well as one's professional responsibilities in practice. Thierauf [15] has described what is called data, information and knowledge model which articulates what constitutes knowledge and what falls under category of information or data. This is summarized by a model in figure 3. Data is unstructured facts and figures that have the least impact on the typical manager Information [15].For data to become information, it must be contextualized, categorized, calculated and condensed [8]. Despite different definitions of knowledge, it is necessary to understand that knowledge is a strategic resource and contributes to achieving a competitive advantage [16].

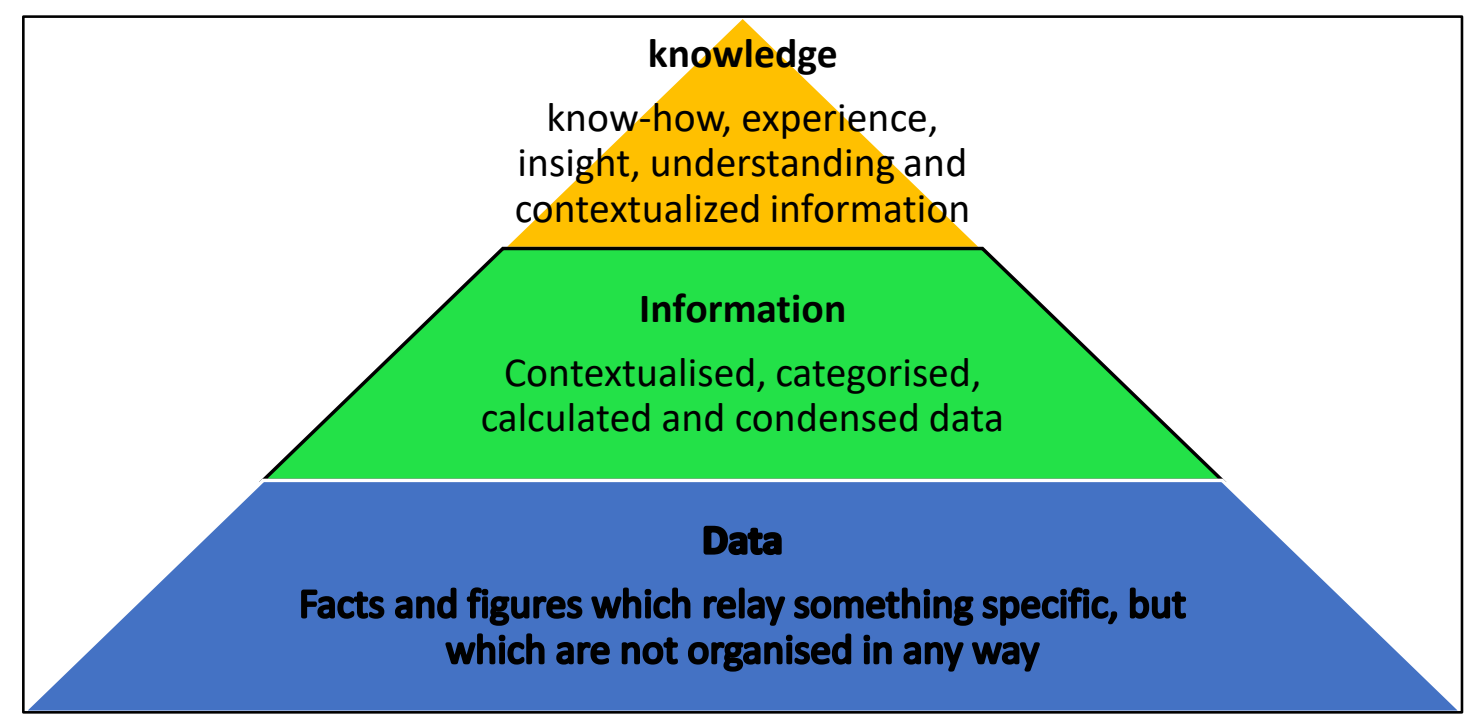

Figure 3 - The knowledge, information and data model hierarchy [17] 


\subsection{Knowledge Management.}

Knowledge management $(\mathrm{KM})$ is described as an integrated, systematic approach to identifying, managing, and sharing all of an enterprise's information assets, including databases, documents, policies, and procedures, as well as previously unarticulated expertise and experience held by individual workers [18]. Furthermore, Yee, Tan, and Tharasamy [16] describe knowledge management as the systematic management of an organization's knowledge assets for the purpose of creating value and meeting tactical and strategic requirements. Another definition is that $\mathrm{KM}$ is performing the activities involved in discovering, capturing, sharing, and applying knowledge so as to enhance, in a cost-effective fashion, the impact of knowledge on a unit's goal achievement [19]. Tsoukas and Vladimirou [20] suggests that knowledge management is a dynamic process of turning on unreflective practice into a reflective one by elucidating the rules guiding the activities of the practice, by helping to give a particular shape to collective understandings and by facilitating the emergence of heuristic knowledge. Pritchard [11] points out that knowledge management as a corporate function has two main objectives: a) improve the exploitation of knowledge resources of an enterprise and $b$ ) protect the knowledge resources of an enterprise.

\subsection{Knowledge Management System}

Dalkir [21] defines knowledge management systems (KMSs) as tools to support KM. This definition is more refined by describing KMSs as the integration of technologies and mechanisms that are developed to support the four principal KM processes, being discovery, capturing, sharing and application of knowledge [9]. This is supported by Alavi and Leidner [22] who defined Knowledge management systems (KMS) as a class of information systems applied to managing organizational knowledge. That is, they are IT-based systems developed to support and enhance the organizational processes of knowledge creation, storage/retrieval, transfer, and application [22]. It is of utmost importance to note that a knowledge management system enables an organization to using strategic know-how effectively for competitive advantage in the global economy and the organization can capitalize on knowledge flows generated through systematic approaches of managing know-how, best practices, and standard operating procedures [16]. 


\subsection{Community of Practice}

An example of a KM tool is a Community of Practice (COP) website. A community of practice connects people from similar domains, allowing them to share and adopt a body of knowledge. This knowledge is put into practice and internalized by members of the community [23]. Although ideas are formed in the minds of individuals, interaction between individuals typically plays a critical role in developing these ideas. That is to say, "communities of interaction" contribute to the amplification and development of new knowledge [24]. According to Wenger, members share competencies that distinguish them from nonmembers, and engage in joint activities and discussions, help each other, and share information and in the process develop a shared repertoire of resources: experiences, stories, tools, and ways of addressing recurrent problems [25]. Radziwill adds that by facilitating increased, relevant interactions between people, COPs often improve organizational effectiveness and they can be initiated as a performance-improvement intervention at the individual, group and organizational levels [26].

The SECI model describes interactions between tacit and explicit knowledge leading to creation of new knowledge through socialization, externalization, combination and internalization [12]. Socialization involves sharing of tacit knowledge between individuals. Chandra, Lyer, and Raman, [27] support SECI model in that in COPs there should be socialization which would enable knowledge push and knowledge pull. Externalization requires the expression of tacit knowledge and its translation into comprehensive forms that can be understood by others. Combination involves the conversion of explicit knowledge into more complex sets of explicit knowledge. Internalization is the conversion of explicit knowledge into organization's tacit knowledge [24] [12].

\subsection{Tools that support COPs}

Tools that support COPs should be able to facilitate processes described by the SECI model so that it can bring benefits to an organization [12]. Here are the characteristics of such tools:

1) Facilitate asynchronous communication, [28] [27] [29],

2) Facilitate synchronous communication [29] [30] [23],

3) RSS Feeds [27] [31],

4) Customizable [30] [32], 
5) Easily Navigated and searched [30] [31] [32] [33].

\subsubsection{Characteristics of COP support tools}

Tools should be able to facilitate asynchronous communication. [28] Ability to create discussions is but another important asynchronous method that tools which support COPs should have. Chandra, Lyer, and Raman [27] suggest that COPs should be able to crease discussions as a way to facilitate socialization. Effective communication in the form of dialogue maximizes individual as well as group learning [29].

Synchronous interactions are more fruitful where a COP is a small group. Members should be flexible to choose which kind of interaction they prefer to use. [29] Synchronous interactions can be facilitated by use of instant messaging (CHAT) [30]. Furthermore, Baker-Eleveth, Sarker, and Eveleth [23] posit that chats are more analogous to face-to-face interaction and are more likely to create a dialogue effect. There are other tools that utilize audio and or video as a way of facilitating synchronous communication.

A COP tool like COP website should enable its members to subscribe to certain feeds so that they can get latest information via email on their topics of interest. [27] RSS feeds are becoming increasingly available, more ubiquitous means of linking and collating disparate information sources and data streams. [31]

A COP tool more especially a website or a social enterprise network should have a capability to enable its members to create different groups depending on their different categories in a certain knowledge domain [27] [29]. Dotsika [34] mentions that the four types of social actions are instrumental, communicative, discursive, and strategic. In viewing this social actions from IT viewpoint, under discursive social action, customization and configuration of online discussion groups is of great importance. Another aspect that should be customizable to a COP user is the user Interface. This includes changing of background, font and other components of the interface as per users' own choice [30]. Usability of a socio-technical system addressing user interactions with technology, indicating user interface ease of use and task facilitation effectiveness is similar to ease of use and usefulness in technology acceptance model (TAM). [32] This means there should be a thorough interface design and user involvement from scratch in the development of a COP so that all the important interface design aspects are captured into the design process. 
Attributes that contribute to Knowledge Management maturity include Navigation and Search ability. [27] The search facility should ideally be able to search all internal documents, links, and messages, with an option to search by type of file [31]. Tang and Yang [30] suggest that discussion boards should be classified and indexed and the COP should allow for keyword searching for documents. These two aspects support Technology Acceptance Model (TAM) which is made up of Perceived Usefulness (PU) and Perceived Ease of Use (PEOU) [32]. If a COP user is able to navigate the COP website and search for forums and documents smoothly, then the Perceived Ease of Use (PEOU) will be achieved [33].

These characteristics have to be taken into consideration when selecting or building a tool that supports a COP. There are other non-functional characteristics that should still be taken care of like security, performance of the system and so on.

\subsubsection{Common COP support tools}

There are different tools that are already available out there to support different COPs depending on its needs. Crosby [35] states that it is important for one to understand tools capacities when choosing the best to support a COP. Crosby further makes reference to some of the tools as listed in Table 1.2 below: [35]

Table 1.2: Tools that support COPs [20]

\begin{tabular}{|c|l|}
\hline \multicolumn{1}{|c|}{ Tool } & \multicolumn{1}{|c|}{ Definition } \\
\hline 1. Social intranet & $\begin{array}{l}\text { These are intranet platforms that were born social. They } \\
\text { incorporate most of the tools that are listed below. Examples } \\
\text { include Jive, Newsgator, Tibbr, Yammer, MangoApps, and } \\
\text { ThoughtFarmer. }\end{array}$ \\
\hline 2. Profiles & $\begin{array}{l}\text { These are tools that enable employees to post information } \\
\text { about their own interests, photos, status updates on what } \\
\text { they are doing. }\end{array}$ \\
\hline 3. Wikis & $\begin{array}{l}\text { At their simplest level, they are web pages that can be edited } \\
\text { by anyone who has been given access to them. Inside } \\
\text { organization, wikis can be used for writing and collecting } \\
\text { information. }\end{array}$ \\
\hline
\end{tabular}




\begin{tabular}{|c|c|}
\hline 4. Blogs & $\begin{array}{l}\text { Blogs allow for postings to be made by individuals in a } \\
\text { chronological order. Inside organizations, blogs may be } \\
\text { created to facilitate communication from a leader, team, } \\
\text { department or an individual expert. }\end{array}$ \\
\hline 5. Microblogging & $\begin{array}{l}\text { This is a tool ideal for informal communications. It } \\
\text { encourages staff to send out fast, simple messages where } \\
\text { they may otherwise hesitate because they might not have } \\
\text { significant content for an email message. }\end{array}$ \\
\hline 6. Forums & $\begin{array}{l}\text { Forums allow for discussions to take place on each } \\
\text { participants own time. Discussion is structured so that topics } \\
\text { and sub-topics are broken down into separate streams with } \\
\text { replies posted below the first comment or question. }\end{array}$ \\
\hline $\begin{array}{l}\text { 7. Groups and } \\
\text { Communities }\end{array}$ & $\begin{array}{l}\text { Separate discrete space may exist in a COP website / } \\
\text { intranet for groups or communities. This space may have } \\
\text { different functionalities including forums, calendar, sharing of } \\
\text { files, and wikis for authoring content. Groups may be used to } \\
\text { gather documented knowledge such as notes from meetings, } \\
\text { video recordings and presentation slides. }\end{array}$ \\
\hline 8. Chat & $\begin{array}{l}\text { This is an older form of electronic communication which } \\
\text { allows for one-on-one messages as well as messages } \\
\text { between smaller groups in real time. Examples of such tools } \\
\text { include skype and WhatsApp. }\end{array}$ \\
\hline $\begin{array}{r}\text { 9. Video } \\
\text { audio }\end{array}$ & $\begin{array}{l}\text { Many videos or audios are used for short instructional } \\
\text { purposes on a number of topics for personal learning, and } \\
\text { some are used for professional development and training. } \\
\text { However there are some tools such as skype, facetime, } \\
\text { WebEx and Blackboard Learn which are now used for } \\
\text { facilitating video conferencing. }\end{array}$ \\
\hline
\end{tabular}




\begin{tabular}{|c|l|}
\hline 10. Podcasts & $\begin{array}{l}\text { Unlike one-off audio or video files, podcasts are audio or } \\
\text { videos done as a show or in a series. They may be listened } \\
\text { or watched on a computer or on a mobile device. }\end{array}$ \\
\hline $\begin{array}{c}\text { 11. RSS Feeds } \\
\text { and }\end{array}$ & $\begin{array}{l}\text { All blogs and many new sources on the public Internet have } \\
\text { associated feeds, often known as RSS or Really simple } \\
\text { syndication. Monitoring many websites and news sources } \\
\text { through RSS is much faster than regularly visiting numerous } \\
\text { Websites or randomly hunting through the Internet. }\end{array}$ \\
\hline
\end{tabular}

There are different studies that showcase impact of different knowledge management tools or systems on organizations' processes. Choi, Ahn, Jung and Kim [36] did a study on large and mid-sized companies in Seoul, Gyeonggi and other regions of Korea. This study focused on communities of practice and knowledge management systems, and their effect on knowledge management activities and innovation performance. Furthermore, they tested effects of knowledge management on innovation performance. Their findings show that communities of practice and knowledge management systems have positive effect on innovation performance. Another finding is that knowledge management activities have a positive effect on innovation performance and community of practice does have a positive effect on innovation. This is supported by study done by Palacios-Marques, Popa and Mari [37] which was carried out on 289 Spanish firms from knowledge intensive industries of biotechnology and telecommunications. Their results show that there is a positive effect on the use of online social network for internal and external cognitive process on knowledge transfer which help firms to stimulate creativity and innovation. Hara and Hew [38] did a case study which focused on examining the types of activities that nurses take on an online community of practice as well as different kinds of knowledge that they share with one another. They discovered that the most common type of activity undertaken by nurses on the online platform was knowledge sharing (sharing a book knowledge or practical knowledge) followed by solicitation (request for help or ideas). The most common types of knowledge shared were institutional knowledge and personal opinion. Bolisani and Scarso [39] did a case on a small IT company to identify factors affecting the use of wiki to manage knowledge in a small company. Their findings are that wiki technology, being light and user-friendly can be particularly be suited for small 
companies. This is because the tool was considered by employees as helpful for their daily work in line with their exchange of knowledge. The above presented studies show that adoption of relevant knowledge management tool for an organization enhances organizational processes of knowledge sharing, creation of new knowledge and this leads to innovation and a competitive advantage.

In the process of choosing the best tool to use, one has to make a decision on whether to use commercial off-the-shelf tools or to develop a tool that can meet his or her requirements. Commercial tools might come with most of the requirements but the cost is usually high and the tool might not meet all the requirements. It is a great idea to develop a COP tool that can meet all the requirements at a lower cost. To lower to cost even further it is important to consider using open source software which will require refining and contextualizing the tool to meet the requirements than to develop a tool from scratch. Since COPs are more concerned with facilitating knowledge management processes namely knowledge discovery, capture, sharing and application [9], it is key to use Content Management System for developing a COP support tool. A website Content Management System (CMS) is a content management system or software application, usually implemented as a web application, for creating and managing HTML content. A CMS facilitates content creation, control, and editing, including other maintenance functions [40]. There are lots of available open source CMS tools out there. There is a study that was conducted by Mafereka and Winberg [6] whose aim was to compare three famous CMS systems namely Drupal, WordPress and Joomla with respect to development of an online support system for a COP. The results of the study depict that WordPress showed greatest ease in configuring and quickly getting together a website with the essential aspects needed for a COP website. Drupal took the lead in terms of flexibility and scalability. It is worth noting that Joomla was good in terms of flexibility of content position and modules integration, and provided a wide range of compatibility with other web tools and plugins, and good support for integration with other languages related to website services, in particular JavaScript. WordPress requires the website developer to have little or no programming skills, whereas Drupal and Joomla requires some programming skills. All three CMSes are suited to COP websites because each has the modules necessary for handling the identified COP's online support system's requirements, either included in the install package, or as add-ons. The authors concluded that the main deciding factor between 
the three open source systems is in terms of the programming skills of the individuals who will be responsible for developing and maintaining the COP website.

Drakos [41] suggests a step by step process that one can follow in selecting a knowledge management program for an organization as shown below:

Step 1: identify knowledge artifacts,

Step 2: identify knowledge flows and transformations,

Step 3: Select technology categories,

Step 4: perform gap analysis (this is in terms of already existing technologies in an organization.

Step 5: evolve and integrate into a coherent solution.

\subsection{Challenges that organizations encounter with knowledge management}

This section focuses on the challenges that organizations encounter which relate to knowledge management. The first challenge is that employees of most organizations have tacit knowledge which is not translated into explicit knowledge and when they leave such an organization, they will leave with that knowledge which is not captured anywhere. Ashkenas [42] posits that organizations spend a lot of time and resources developing knowledge and capability. While some of it gets translated into procedures and policies, most of it resides in the heads, hands, and hearts of individual managers. Overtime, much of this institutional knowledge moves away as people take on new jobs, relocate, or retire. Kalkan [43] highlights that is it is the tacitness that makes knowledge difficult to imitate and therefore an important organizational resource for sustaining competitive advantage. He further points out that there should be a balance between focusing on tacit knowledge and utilizing Information, that is, organizations should not rely on IT but use IT as an integral component of knowledge management process.

The second challenge relates to inappropriate organizational culture. Because organizational culture is a key element of managing organizational change and renewal, inappropriate culture is generally regarded as the key inhibitor of effective knowledge sharing [43]. A knowledge-oriented culture challenges people to share 
knowledge throughout the organization [43]. Gupta, lyer and Aronson [44] share in their research that organizational culture is a critically important aspect for facilitating sharing, learning and knowledge creation. They further state that open culture with incentives built around integrating individual skills and experiences into organizational knowledge will be more successful.

Thirdly, there is a challenge that knowledge systems in some firms are immature. Effective knowledge management require technological support [44]. There are different technologies that are used to support knowledge management processes. Kalkan [43] points outs that besides, processing data and information, IT implementation and advancement must have a knowledge-oriented focus. Knowledge creation must be targeted finally. System design and working principles of IT professionals must reflect this focus. To provide this is among the responsibilities of the management [43].

Furthermore, less attention to human resources can be detrimental to knowledge management initiatives. The success of any knowledge management initiative is likely to be critically dependent on having competent and suitably motivated people taking an active role in the process [43]. Oliva [45] concluded through his research on Brazilian companies that lack of interest from employees, lack of competent staff and lack of incentive are some of the main barriers that compromise better knowledge management.

Lack of leadership support is a challenge that can lead to knowledge management's failure. If knowledge management initiatives do not have full leadership support, it means those leaders are supporting something else. Soakell-Ho and Myers [46] found out that lack of leadership support from Board to top-tier management within an organization in the domain of Knowledge Management is one of the challenges that many organizations are faced with.

\subsection{Knowledge management maturity assessment}

Before companies kick off knowledge management initiatives, it is wise for them to understand their current knowledge management practices and identify areas lacking effective practice. According to de Sticker [47] knowledge audit, knowledge assessment, information audit, gap analysis, needs assessment, library services study, information services study and knowledge resources inventory are some of the 
processes that can be used to measure knowledge management maturity before kicking off knowledge management related project. Henczel [48] has developed a model which clearly defines the difference between needs analysis, information audit and knowledge audit as depicted in figure 5.

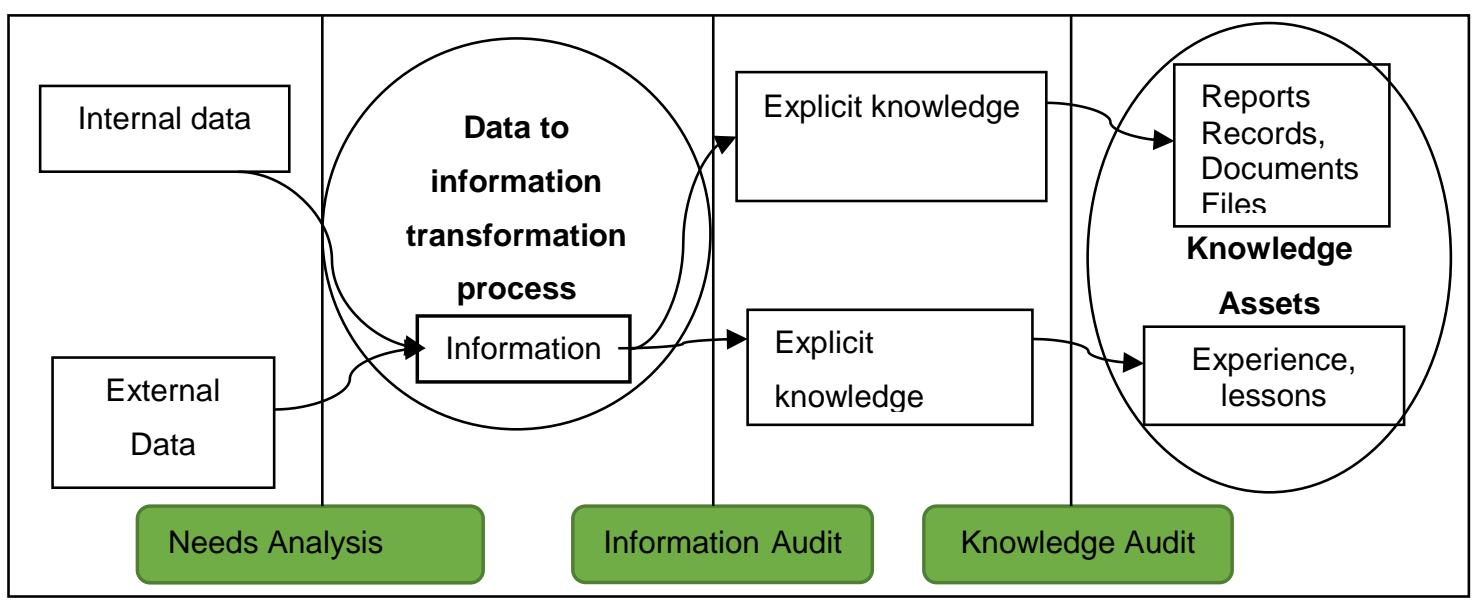

Figure 4 - Model which clearly defines the difference between needs analysis, information audit and knowledge audit [24]

Needs analysis is a process by which information users are asked precisely what information resources or services they need to perform their jobs. Information audit goes a step further in not only finding out what information resources and services people need to do their jobs, but how those information resources and services are actually used. It further enables one to map information flows within an organization and between an organisation and its external environment. Knowledge audit is conducted to identify organisation's knowledge assets, how they are produced and by whom. It further enables one to assign a level of strategic significance or importance to knowledge assets. [48]

Benefits of doing a knowledge audit or assessment are as follows: [47]

- Helping the organization clearly identify what knowledge is needed to support overall organizational goals and individual and team activities.

- Giving tangible evidence of the extent to which knowledge is being effectively managed and indicating where improvements are needed. 
- Providing an evidence-based account of the knowledge in an organization and tracking how that knowledge moves around in, and is used by, the organization.

- Presenting a map of what knowledge exists where in the organization, revealing gaps and duplication.

- Identifying pockets of knowledge that are not currently being used to good advantage and therefore offer untapped potential.

- Providing a map of knowledge and communication flows and networks, revealing examples of good practice and blockages and barriers to good practice.

- Presenting an inventory of knowledge assets, allowing them to become more visible and therefore more measurable and accountable, and giving a clearer understanding of the contribution of knowledge to organizational performance.

- Supplying vital information for the development of effective knowledge management programs and initiatives that are directly relevant to the organization's specific knowledge needs and current situation.

In the literature, there are different research papers that have been published which focus on knowledge management maturity models. Maturity model is described as a specific competency model that points out different degrees of maturity. Its aim lies on the assessment which extent a competence object to fulfil the quality requirement criteria defined for a certain competence object class [49]. Jochem, Geers and Hainze [49] have developed a maturity model which has five levels:

Table 1.3: - Jochem, Geers and Hainze's knowledge management maturity model [25].

\begin{tabular}{|c|l|}
\hline $\begin{array}{c}\text { 1. Level 1- } \\
\text { Initial: }\end{array}$ & $\begin{array}{l}\text { Knowledge intensive process with a non-formal/spontaneous } \\
\text { character regarding the process design and handling of knowledge. }\end{array}$ \\
\hline $\begin{array}{c}\text { 2. Level 2- } \\
\text { Repeated: }\end{array}$ & $\begin{array}{l}\text { Proactive knowledge intensive process with personnel related } \\
\text { /non-formal character regarding the process design and the } \\
\text { handling of knowledge. }\end{array}$ \\
\hline $\begin{array}{l}\text { 3. Level 3- } \\
\text { Defined: }\end{array}$ & $\begin{array}{l}\text { Established knowledge intensive process with a formal character } \\
\text { (defined process knowledge (input and output) with clear }\end{array}$ \\
\hline
\end{tabular}




\begin{tabular}{|c|l|}
\hline & $\begin{array}{l}\text { assignation, defined criteria for quality-oriented process design and } \\
\text { performance). }\end{array}$ \\
\hline $\begin{array}{r}\text { 4. Level 4- } \\
\text { Managed: }\end{array}$ & $\begin{array}{l}\text { Controlled knowledge intensive process with formalised and } \\
\text { proved character (controlled handling of knowledge in the process } \\
\text { (continuous), controlled criteria for quality-oriented process design } \\
\text { and performance. }\end{array}$ \\
\hline $\begin{aligned} \text { 5. Level 5- } \\
\text { Optimised: }\end{aligned}$ & $\begin{array}{l}\text { Sustainable knowledge intensive process (optimized and } \\
\text { comprehensive handling of knowledge (continuous, up to date, } \\
\text { holistic); optimised and quality-oriented process design with } \\
\text { continuous improvement). }\end{array}$ \\
\hline
\end{tabular}

Islam, Walton, Egbu and Gupta [50] have develop a maturity model that has three levels which are used to measure what they call management variables and communication variables:

Table 1.4: Islam, Walton, Egbu and Gupta's Knowledge management maturity model [26]

\begin{tabular}{|r|l|}
\hline Level 1: & Barely exist but not implemented. \\
\hline Level 2: & Occasional use if the company use it. \\
\hline Level 3: & $\begin{array}{l}\text { Fundamentally ingrained in the company vision, mission, strategy and } \\
\text { operations. }\end{array}$ \\
\hline
\end{tabular}

Olivia [45] has developed a maturity model that has four levels as shown below:

Table 1.5: Olivia's Knowledge Management Maturity Model [27]

\begin{tabular}{|l|l|}
\hline $\begin{array}{l}\text { Level 1: Insufficient } \\
\text { knowledge }\end{array}$ & $\begin{array}{l}\text { Little awareness about the importance of Knowledge } \\
\text { management }\end{array}$ \\
Management for the efficiency and effectiveness of \\
business. There is no physical or conceptual structure \\
dedicated to Knowledge Management. There is eventual \\
adoption of Knowledge Management Practices in non- \\
structured manner.
\end{tabular}




\begin{tabular}{|l|l|}
\hline $\begin{array}{l}\text { Level 2: Structured } \\
\text { Knowledge } \\
\text { Management }\end{array}$ & $\begin{array}{l}\text { There is awareness in terms of importance of Knowledge } \\
\text { Management for the business. There are organised and } \\
\text { frequent knowledge Management practices. Existing } \\
\text { information systems provide average support to knowledge } \\
\text { management. }\end{array}$ \\
\hline $\begin{array}{l}\text { Kevel 3: Oriented } \\
\text { Manowledge }\end{array}$ & $\begin{array}{l}\text { The Company is oriented to the creation and use of } \\
\text { knowledge to leverage its business. There is a culture of } \\
\text { innovation rooted in the organizational processes. }\end{array}$ \\
\hline $\begin{array}{l}\text { Level 4: Integrative } \\
\text { Knowledge }\end{array}$ & $\begin{array}{l}\text { There are high characteristics of awareness, organization } \\
\text { and transparency regarding processes related to knowledge } \\
\text { management. Knowledge Management is more } \\
\text { decentralised. The corporate Knowledge Management is } \\
\text { guided by the participation of most employees. }\end{array}$ \\
\hline
\end{tabular}

Khatibian, Hasan, and Jafari [51] have developed a knowledge management maturity model and their model is inspired by Capability Maturity Model integrated (CMMI). Characteristics and features of the model are summarised below:

Table 1.6: Khatibian, Hasan, and Jafari's Knowledge Management Maturity model [28]

\begin{tabular}{|l|l|}
\hline Level 1: Initial & $\begin{array}{l}\text { Implementation is in irregular and undefined form and } \\
\text { informs nothing of its concept and congenital application in } \\
\text { an organization. A certain number of processes and } \\
\text { strategies designed and devised for knowledge } \\
\text { management are executed in the organization in an } \\
\text { unconscious way but in systematic form with no uniformity. }\end{array}$ \\
\hline Level 2: Managed & $\begin{array}{l}\text { Policies ad decision-making units are provided for } \\
\text { knowledge management project implementation. } \\
\text { Knowledge-oriented assets of an organization are identified. } \\
\text { Primary Structures are made to implement knowledge } \\
\text { management in the organization. }\end{array}$ \\
\hline
\end{tabular}




\begin{tabular}{|l|l|}
\hline Level 3: Defined & $\begin{array}{l}\text { Technical requirements study is made at this level. Focusing } \\
\text { at this level is always exercised on two variables: strategy } \\
\text { and human resources. The processes have been properly } \\
\text { described and understood; similarly all standards, policies, } \\
\text { tools and methodologies were illustrated, documented and } \\
\text { integrated. A good organizational structure is defined to } \\
\text { implement knowledge management, roles and } \\
\text { responsibilities of Knowledge Management functions. }\end{array}$ \\
\hline Level 4: & $\begin{array}{l}\text { At this level the organization is beginning to measure the } \\
\text { Knowledge Management Objectives and determine to what } \\
\text { level a market share and organization profitability are } \\
\text { increased, compare them with Knowledge Management } \\
\text { strategies and long-term goal and provide strategies to } \\
\text { improve them. The partnership or involvement culture } \\
\text { governs and on this basis, the staff are both managed and } \\
\text { involved. }\end{array}$ \\
\hline Level 5: Optimizing & $\begin{array}{l}\text { This is the top level. At this level the organization uses its } \\
\text { pro-found knowledge to continuously improve the } \\
\text { processes. Some systems are established to learn about the } \\
\text { past experiences and improve our learning culture. The } \\
\text { organization has a good system to measure the outcomes of } \\
\text { accomplished Knowledge Management Project. Innovation } \\
\text { and creativity culture are strengthened. The procedures and } \\
\text { concepts of Knowledge Management are embedded in the } \\
\text { treatment of personnel, business processes and } \\
\text { organization's knowledge oriented culture. There shall be an } \\
\text { effective relationship between knowledge Management and }\end{array}$ \\
\hline
\end{tabular}


The next section covers the Methodology also known as experiment design. Its aim is to present the research methods or approach that have been used in this research project. 


\section{Methodology}

This chapter describes the methodology that is followed in this research project, the aim of which focuses on enhancing business processes using Knowledge Management System. Below are the objectives of this research:

i) Identify the core problem with respect to knowledge management.

ii) Come up with the Solution to the core problem with respect to knowledge management.

iii) Design the Solution Prototype.

iv) Develop and test a solution prototype.

Use parts of the Rational unified Process, Prince 2, Systems engineering and software engineering techniques in implementing a design according to the above solution plan.

The methodology followed in this research paper is depicted in

below. IT was designed through integration of components of Rational Unified Process (RUP) [5], Systems Engineering [52] and Software Engineering techniques or processes [4]. Prince 2, Project Management Methodology is used to manage the research project end-to-end [3]. It is made up of two main parts: a) Exploration of the problem space and b) Exploration of the solution space as influenced by system methodology [4]. A non-governmental organization (NGO) is used in the research as a case study and its name will not be mentioned for confidentiality purposes.

\subsection{Exploration of problem space}

One of the important steps in research is to justify the specific research problem and to subsequently justify the value of the solution proposed [53]. This phase namely exploration of problem space looks into the following points: 1) there is justifiable reason to start the research project, and 2) the justification should remain valid throughout the project and it should be well documented and approved. [3]. In the Rational Unified Process terminology, this stage is called the inception phase. The goal of the inception phase is to achieve concurrence among stakeholders on all the lifecycle objectives and to ensure that the project is both worth doing and possible to do [5]. To make sure that this vital step is carried out thoroughly, three processes namely, collecting data, analysing data and identifying the Project Intervention logic 
are followed. [54]. These steps are crucial in identifying the problems that the organization under this research is faced with. This is also known as needs analysis as shown in

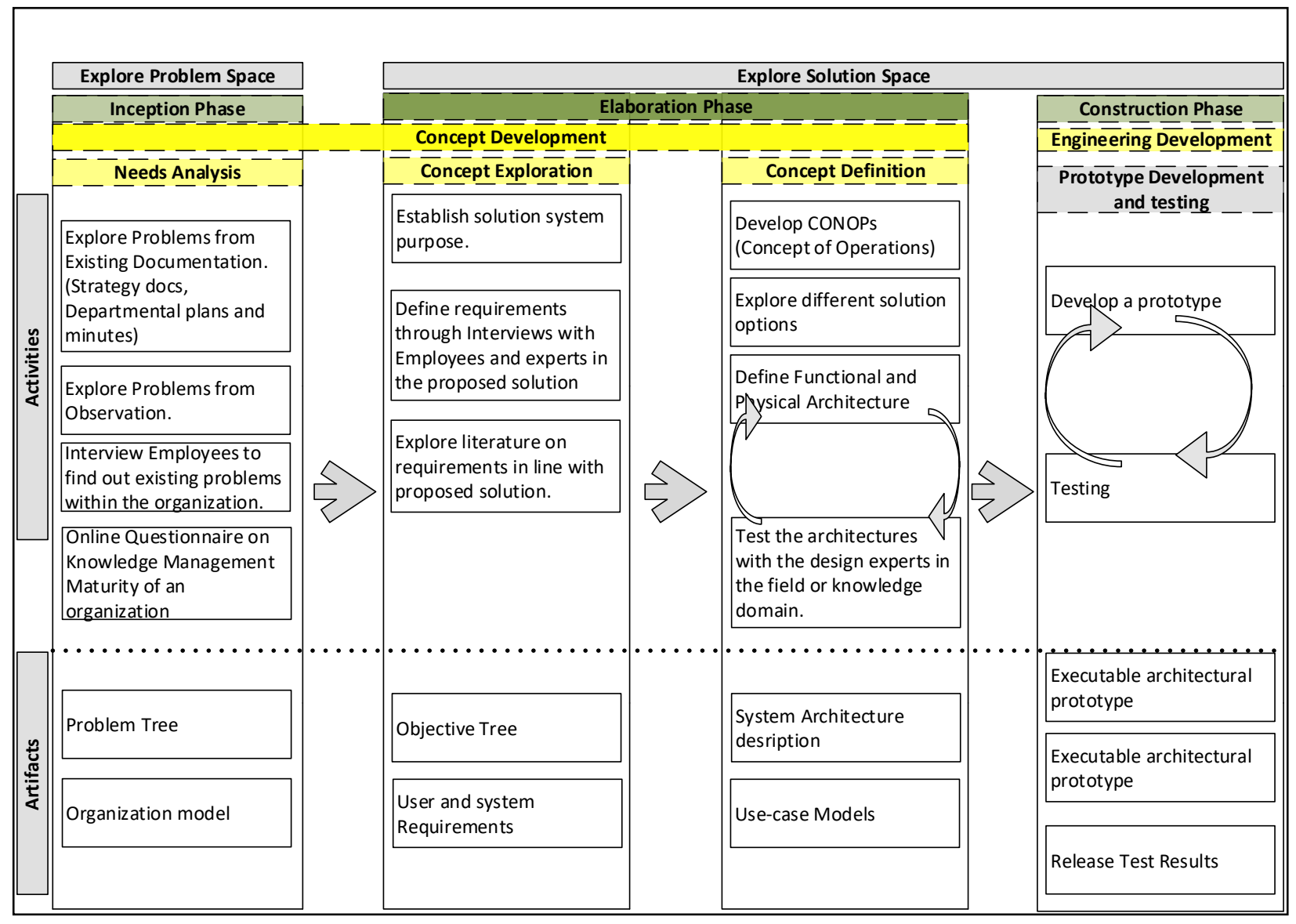

Figure 5 - Research methodology followed in this project.

\subsubsection{Data collection}

Non-probability sampling, which is also known by different names such as deliberate sampling, purposive sampling and judgment sampling, is used for selecting individuals who participated in data collection process [55]. In this type of sampling, items for the sample are selected deliberately by the researcher [55]. In other words, under nonprobability sampling the organizers of the study purposively choose the particular units of the population for constituting a sample on the basis that the small sample is selected out of a huge one and it will be a typical or representation of the whole [55]. 
Per and Martin [56] suggest that when collecting data, a method called triangulation should be used to increase the precision of the research. They further mention the different kinds of triangulation method being data (source) triangulation, observer triangulation, methodological triangulation, and theory triangulation. In this research data triangulation is used which utilizes more than one data source for data collection. Therefore, two individuals from each group were identified, for example, central office staff and field office staff, were selected from organization concerned to participate in data collection process. The opening seminar was organized for the selected people to brief them about the research and their involvement. Following the seminar, there was use of primary data collection method through one-on-one interviews with them in order to get the quality data on different knowledge management related problems that they encounter in their work environment [54]. The interviews were semistructured meaning that they contained a mixture of open-ended and specific questions [57]. It was explicitly mentioned to the interviewees that the results of the interview would not be divulged to any other parties. A formal consent was send through by the NGO's Managing Director to give authorisation to proceed with this research process of gathering data from his employees [58]. Interviewees were handled respectfully, regardless of what insights and inputs they provided. The interviewees' time was much respected and appreciation for their contribution of time was shown, regardless of their position within the organization [58]. Another important aspect is that the interviews were recorded and then the recordings were transcribed. All sensitive information was kept secure and anonymised throughout the study. Myers and Michael [58] suggest that it may be advisable sometimes to provide early feedback to subjects and organizations and to confirm particular matters with them that may be unclear. Therefore this interview process was followed by another seminar for giving feedback to the interviewees.

Secondary data was also used to identify problems in relation to knowledge management that the organization studied was faced with. Such data was contained in some of the strategy development documents and departmental meeting minutes.

Furthermore, a semi-structured online questionnaire was developed and used to explore the organization's knowledge management maturity level and this helped in determining if some of the problems identified through interviews, and secondary data sources were due to inefficient business practices in relation to knowledge 
management. This also helped in identifying gaps within the organization pertaining to knowledge management and information or knowledge flow patterns. [45]

\subsubsection{Data Analysis}

The next step is data analysis and this is where different techniques were used to get deeper understanding of the core problem, maturity level of the organisation in this study and to define requirements for a knowledge management support system. Different techniques that were used to analyse data for each method of data collection which was used in the research project are presented by Table 1.

Table 1 - Data collection method and data analysis carried out

\begin{tabular}{|c|c|}
\hline Data collection Method & Data Analysis processes carried out \\
\hline $\begin{array}{l}\text { 1. Interview employees to find } \\
\text { out existing problems in an } \\
\text { organization. }\end{array}$ & $\begin{array}{l}\text { a) Editing, coding, classification, } \\
\text { tabulation [55]. } \\
\text { b) Problem tree analysis [59]. } \\
\text { c) Objective tree analysis [59]. }\end{array}$ \\
\hline $\begin{array}{l}\text { 2. Online questionnaire on } \\
\text { knowledge management } \\
\text { maturity of an organization. }\end{array}$ & $\begin{array}{l}\text { a) Charting, mapping and interpretation } \\
\text { [60]. }\end{array}$ \\
\hline $\begin{array}{l}\text { 3. Define requirements through } \\
\text { interviews with employees } \\
\text { and industry experts. }\end{array}$ & $\begin{array}{l}\text { a) Editing, coding, classification, } \\
\text { tabulation [55]. }\end{array}$ \\
\hline
\end{tabular}

Editing process referred to in the Table 1 above refers to the process of examining the collected raw data to detect errors and omissions and to correct these when possible [55]. Coding refers to the process of breaking down, examining, comparing, conceptualizing, and categorizing data [61]. Classification is the process of arranging data into groups or classes on the basis of common characteristics [55]. Tabulation is the process of summarising raw data and displaying the same in compact orderly arrangement of data in columns and rows [55]. Charting refers to rearranging the data according to the appropriate part of thematic framework to which they relate and forming charts [60]. Mapping and interpretation entail using charts to define concepts, 
map the range and nature of phenomena, create typologies and find associations between themes with a view to providing explanations for the findings [60].

The problem tree provides a simplified but robust version of reality, identifying not only the core problem to be addressed, but also the effects of the core problem, and the underlying issues and root causes that contribute to the current state as depicted in Figure 6 below [59].

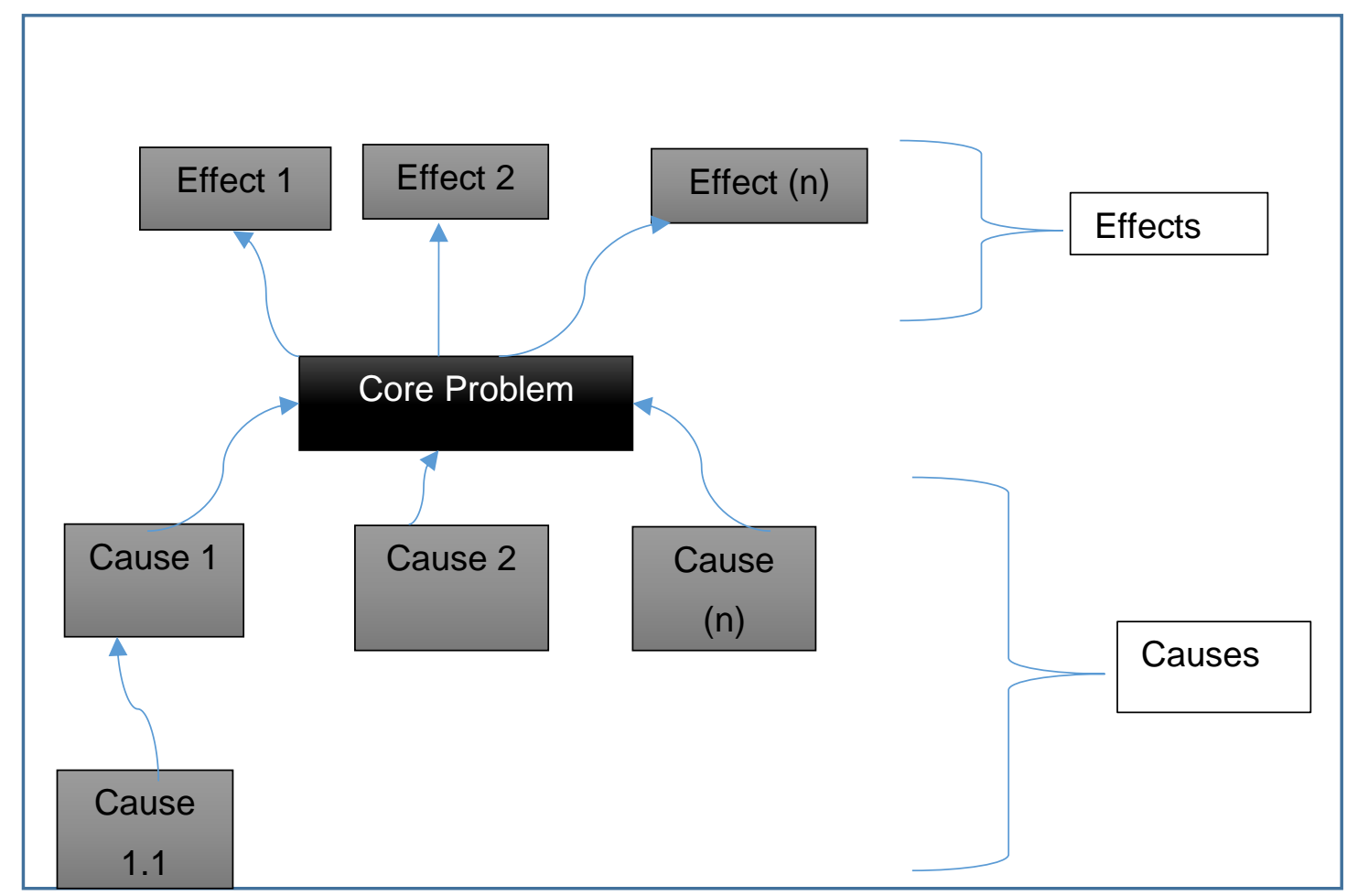

Figure 6 - Illustraction of Problem tree

In the centre of the problem tree is the core problem, then the roots of the tree show the cause of the core problem and there is a possibility that a cause of a core problem can have a cause. The leaves of the tree depicts the effects of the core problem.

The next step that was followed was the exploration of the solution space, which is discussed in the following section. 


\subsection{Exploration of the solution space}

In Systems Engineering terms, the next step after exploration of problem space is named Explore Solution Space which is made up of Concept Exploration and Concept Definition. In the Rational Unified Process terms this stage is called Elaboration phase. [62]. The purpose of the elaboration phase is to analyse the problem domain, establish a sound architectural foundation, develop the project plan, and eliminate the project's highest-risk elements [5]. In this phase the focus is on the following outcomes: usecase model ( $80 \%$ complete), Supplementary requirements, and software architecture description.

\subsubsection{Concept exploration}

In this step, different options to develop the solution were explored, culminating in the final solution to be further designed and implemented. This was done by converting problem tree into alternatives tree also known as an objectives tree. Figure 8 below shows an example of an objectives tree.

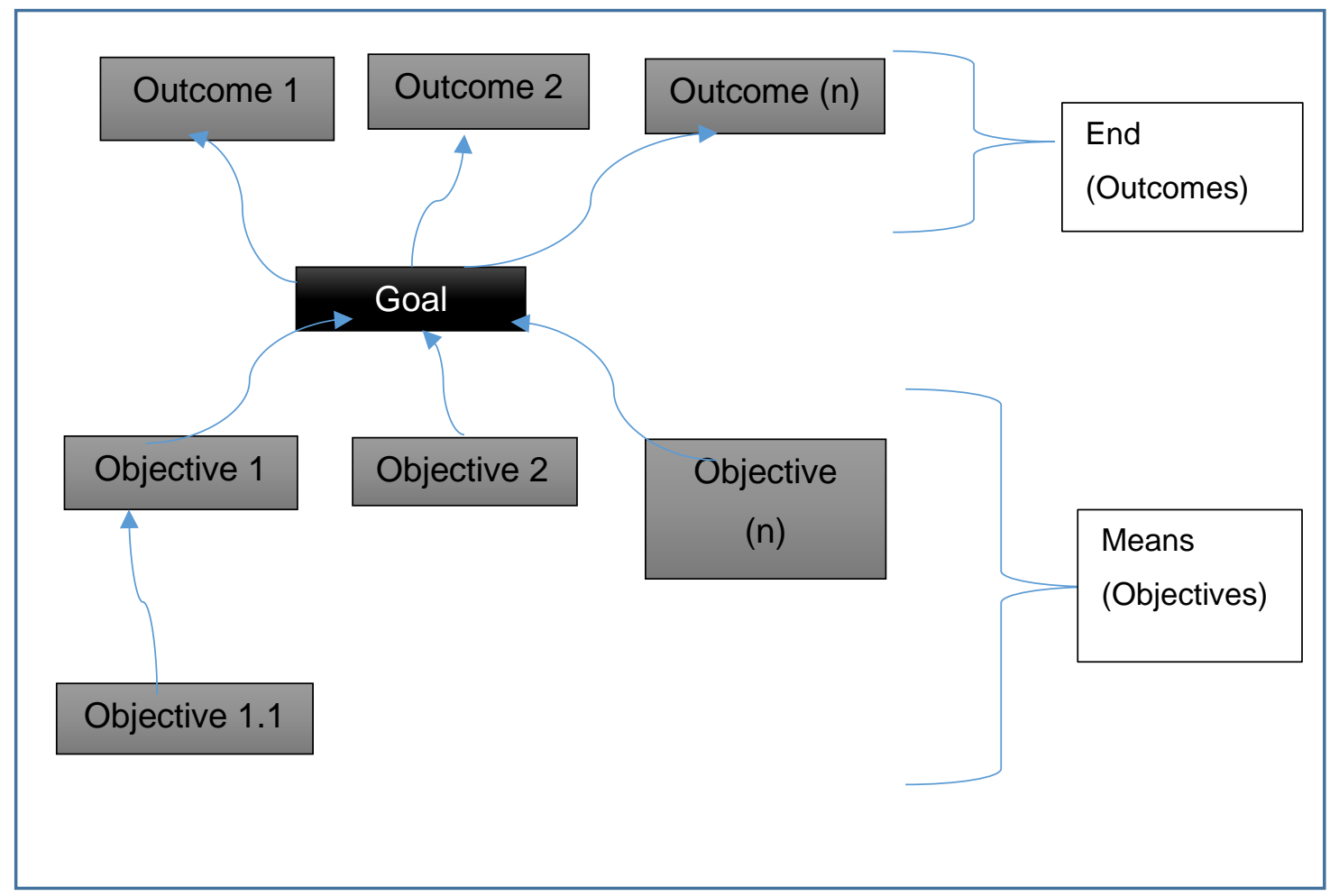

Figure 8 - Objectives tree [59] 
For example cause 1.1 was converted to objective 1 , then the effect 1 was converted to Outcome 1. The objective tree is a depiction of means to an end, that is, how the achievement of the objectives is going to translate into outcomes. The alternatives tree also communicates which elements will not enter into the scope of the project. [59]

After that, prioritization on the problems that were going to be solved was done. This was done because it could be costly and take a lot of effort to solve all problems at one go or in one project. In a nut shell this process was used to define the scope of the project. Interviews with employees were done to define requirements for the proposed solution. [62]

The literature was also explored to come up with the requirements on the proposed solution. Requirements derived from the literature and from the interviews were combined to form one list of requirements which was further analysed and prioritized.

\subsubsection{Concept definition}

In this stage requirements were already in place and the stage was focusing on exploring different solution options and coming up with one which would be used. A solution option was identified, then a system architecture was developed and tested through experts in the knowledge domain [63]. Such tests' output was used to further enhance the architecture designs. Use case Models were also developed and used as inputs to the next steps of prototype development. [5]

\subsubsection{Prototype}

During the construction phase, a prototype was developed and enhanced through different testing methods [62]. Both requirements-based testing and scenario testing techniques were used to make sure that each release meets its requirements and functions properly under different scenarios ${ }^{1}$. Furthermore, Beta testing technique was used as part of user testing in which each release will be made available to users to experiment with it and raise problems that they discover with the developer. [63].

\subsubsection{Transition phase}

The transition phase is entered when a baseline is mature enough to be deployed in the end-user domain. Typically, this means that some usable subset of the system has

\footnotetext{
${ }^{1}$ A scenario is a story that describes one way in which the system might be used. [63]
} 
been completed to an acceptable level of quality and that user documentation is available so that the transition to the user will provide positive results for all parties [5]. This phase includes user testing. Under user testing, acceptance testing will be used to decide whether the system is ready to be accepted to the customer or user environment. For the purposes of this research, this phase is going to focus mainly on brining all findings throughout all the stages together in a thesis paper. Therefore, acceptance testing will not be done as the research only focuses on the prototype not a full-fledged system.

The next section covers the Concept Development. It focuses on needs analysis and knowledge management maturity of the organization under this study. Furthermore, it touches on concept exploration in which requirements gathering process is detailed. 


\section{Concept development}

This chapter covers needs analysis and it is more on exploration of the problem space is system design terms. Under needs analysis interviews with employees of the organization under this study were conducted to understand some of the problems that are faced by this organization. Furthermore, an online survey was designed as a way to gauge the organizations level of maturity with regard to knowledge management.

\subsection{Needs analysis}

As described in chapter 3 section 3.1.1, the methodology followed in this research kicks off with doing needs analysis to uncover problems faced by the organization under the study. This section covers presentation and discussion of results of interviews with the organization's employees.

\subsubsection{Interviews with employees}

A seminar prior to interviews was held so as to describe any technical terms, get participants to know what the interview is all about and also as a platform for participants to ask and comment about any issues in relation to the interviews or the project. After the seminar different one-on-one interviews with employees of the organization under research were done and they were all recorded. The first method used for recording was by using the cell phone, the second one was to use Skype recorder and the third one was through an online tool called WEBEX. The reason behind using different methods of recording was that some participants were a bit far, so Skype and WebEx tools were used to run such interviews.

\section{Discussions of interview results}

In the data analysis displayed by Figure 8 - Problem tree analysis, there are similar issues that were raised by different people and those are highlighted in yellow. On the question focusing on the challenges that each of the employee faces, there are two issues in yellow and those are: Poor implementation of projects by community members after trainings and another one is that there is poor stakeholders engagement in development initiatives. Moving on to the question centered around the things that employees find frustrating, many of the employees shared that moving around the office to find signatories to authorize certain activities was a challenge and also procurement of goods and services for the ADPs (Area Development Programs) 
also took a lot of time to complete. Furthermore, there are solutions that employees think can work to solve some of the problems and those are in yellow; implementation of tools that will enable communication with community members and other stakeholders. On the last question that hammers on where costs go up but the quality goes down, many of the interviewees talked about training of the community members which was expensive but the outcome from those trainings was very low. Majority of the interviewees were thinking that the organization's internal controls were too tight.

Figure 8 is the representation of the problem tree analysis. On the bottom of the tree there are causes, in the middle there is a core problem and on top of the tree there are effects of that core problem. Since in a problem tree it is wise to focus on some of the key issues, the causes and effects that are in yellow were picked as they were repeatedly stressed by most of the interviewees and these are going to be at the center of the project.

Figure 9 illustrates an objectives analysis tree. This is extracted from the problem tree in that the negative statements were turned into positive statements, that is, causes and effects were turned into objectives. The causes became Means and the effects became end products. Likewise yellow boxes are prioritized in terms of focus throughout the project. 


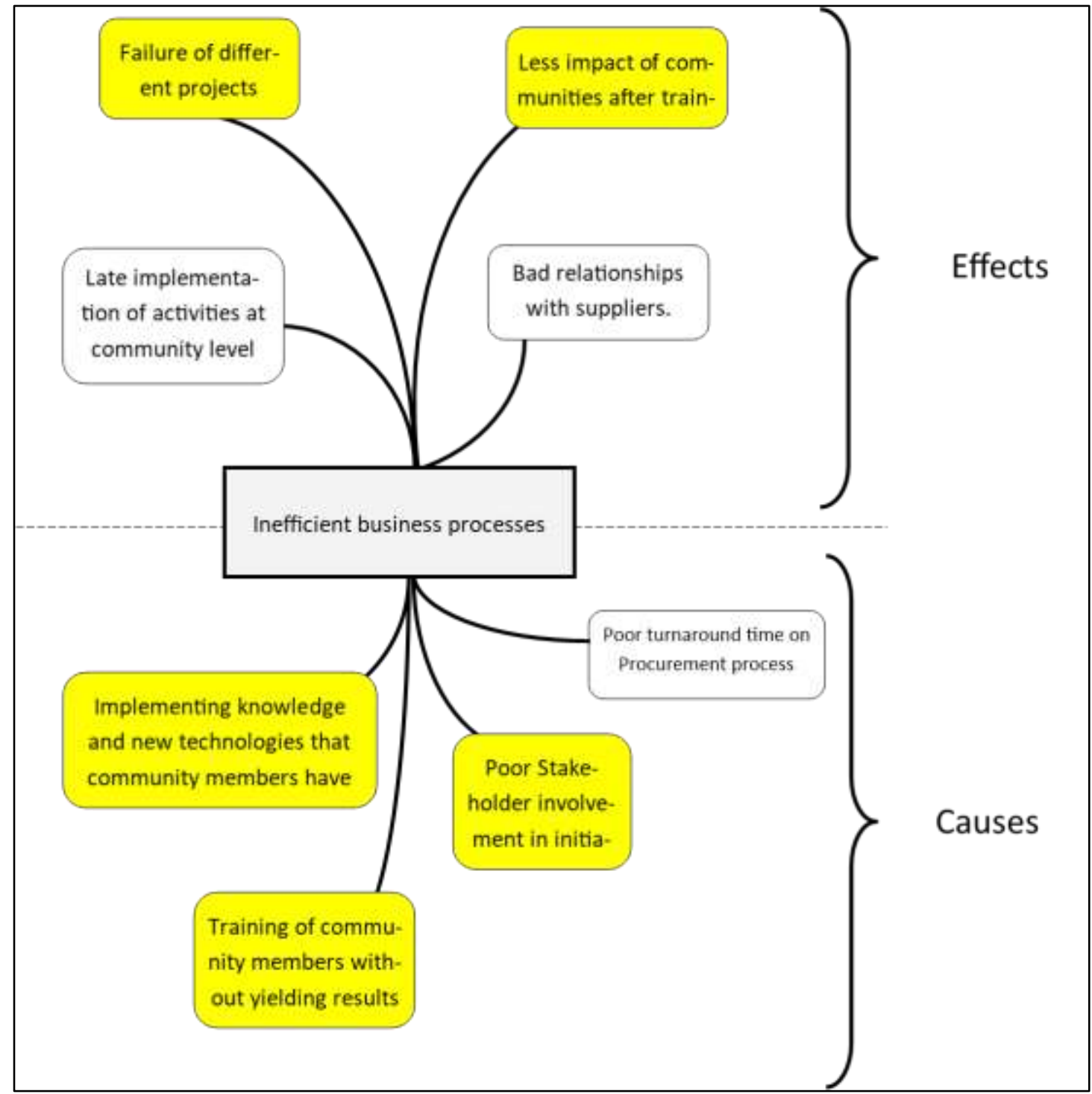

Figure 8 - Problem tree analysis

Then from this analysis we will be drawing logical framework and the business case to give our project a skeleton that is a high level plan with activities, outputs, outcomes and a goal and those will also include tracking aspects like indicators, and risks or assumptions. 


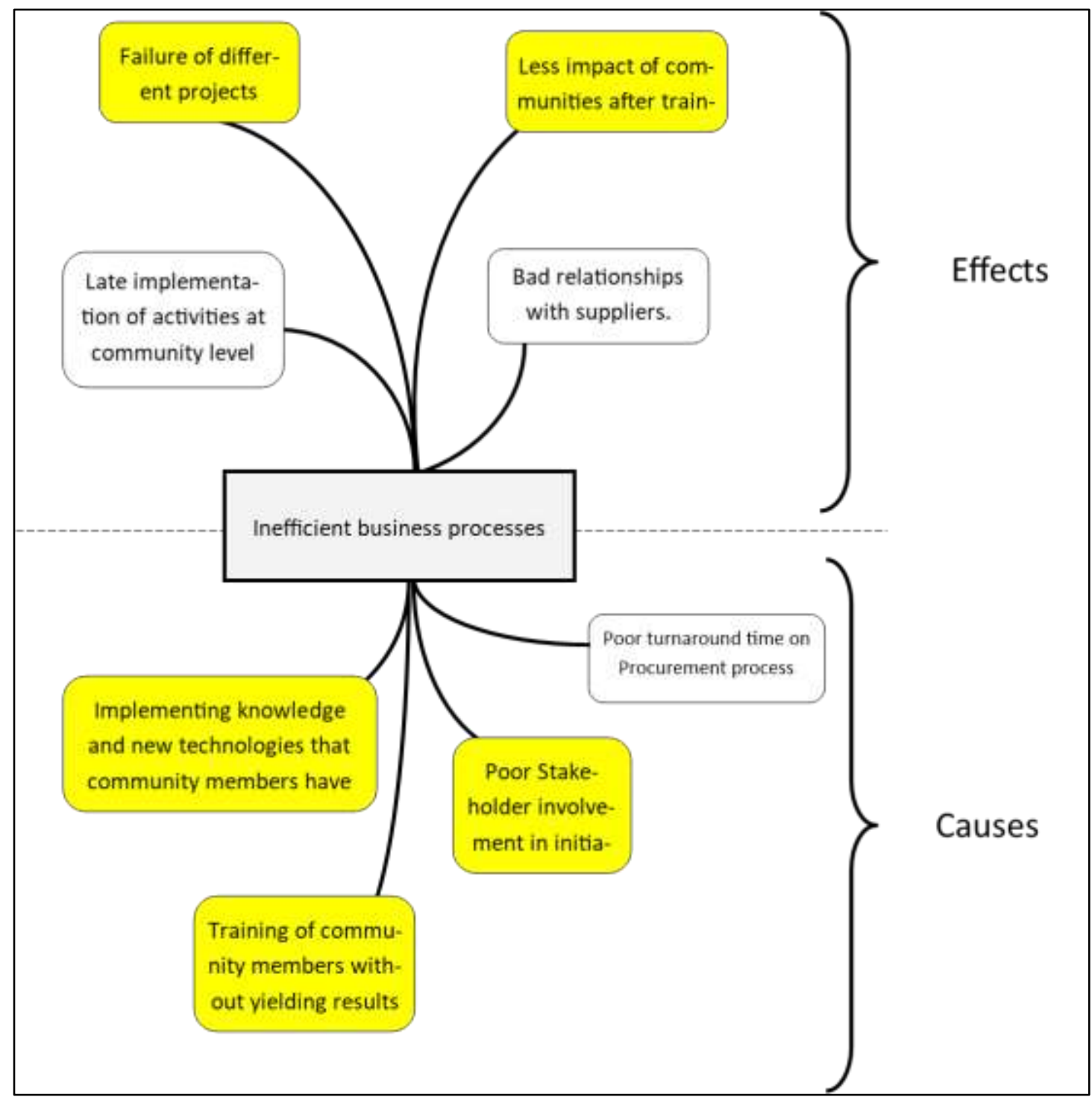

Figure 9 - Objective tree analysis

\subsubsection{Knowledge management maturity}

An online questionnaire was developed with an aim to gauge the level of knowledge management maturity and identify areas lacking effective practice within the organisation under this study. 12 people filled the questionnaire. The questionnaire results are going to be discussed below.

\section{Level of organised practice in KM}

The first question was addressing the level of organised practice in knowledge management within the organisation. Figure 9 is the graphic representation of the 
feedback on this question. Over $40 \%$ of the employees rated the organisation to be at level 3, meaning that the organisation was focusing mainly on managing knowledge management strategy, processes and approaches. However, there is about $30 \%$ of the employees who felt that the organisation was at level 2, meaning that they were of the opinion that knowledge management strategy and its supporting processes were not yet in place but they were being developed.

\section{$\underline{\text { Knowledge Management Department }}$}

The second question was mainly enquiring on whether there was a department responsible for knowledge management. $50 \%$ of the respondents said that there was such a department and $50 \%$ answered no. There seems to be a tie on this question. With further probing on few participants through skype meeting, the understanding was that there is such a department but it is more of a global department serving different countries and there is no such department at the local office.

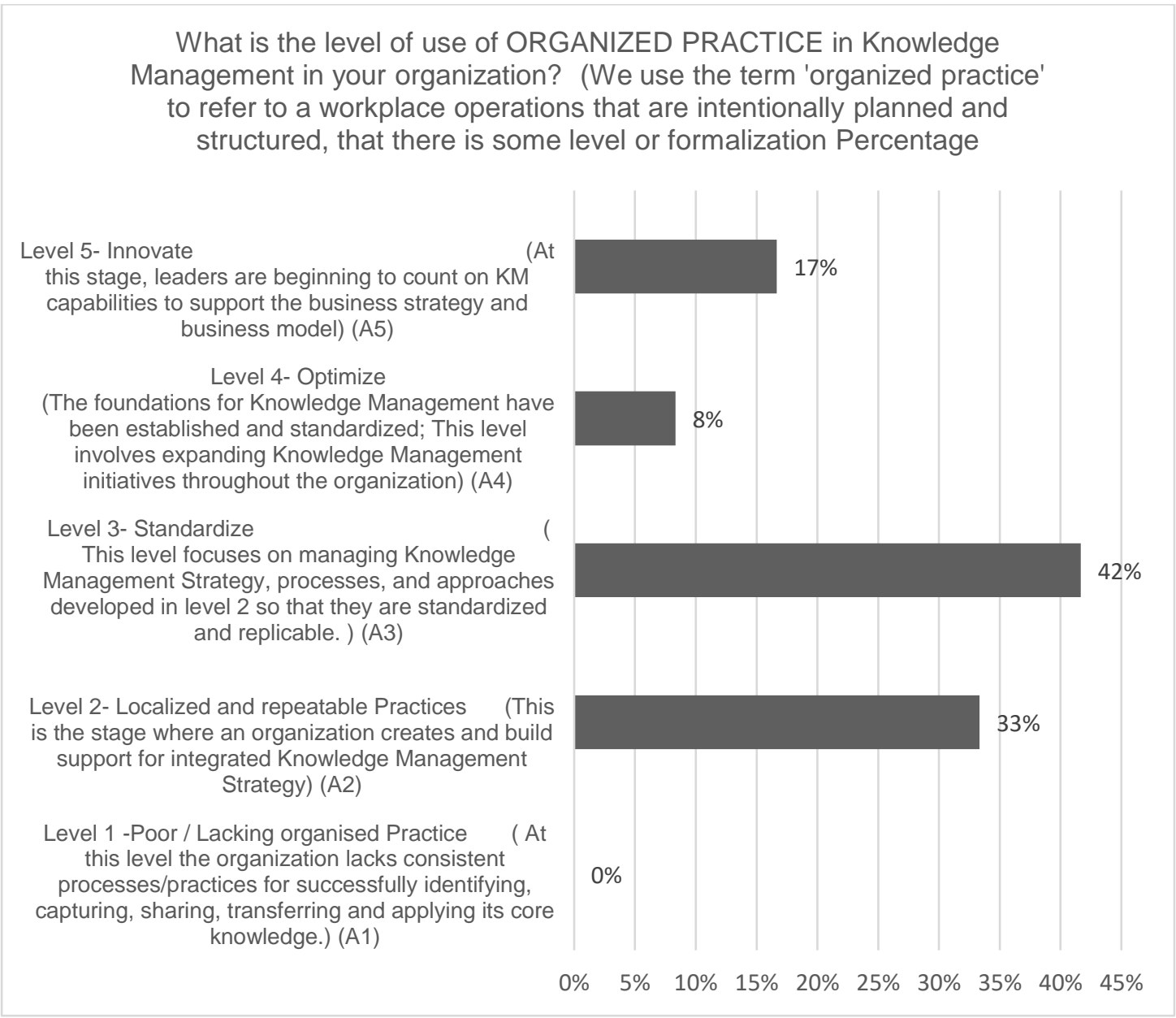

Figure 10 - Level of organized practice in knowledge management 


\section{Discussion of knowledge management in meetings}

About $50 \%$ of the respondents answered that knowledge management is discussed occasionally in their meetings. $25 \%$ answered that it is rarely discussed while the remaining $25 \%$ answered that it is discussed frequently. One can conclude that knowledge management is discussed but in a non-consistent manner within the organisation.

\section{Level of Information system use for KM}

The responses on the level of information system use for knowledge management were from average and above average and there were respondents who have answered that it was excellent as depicted in Figure 11 below.

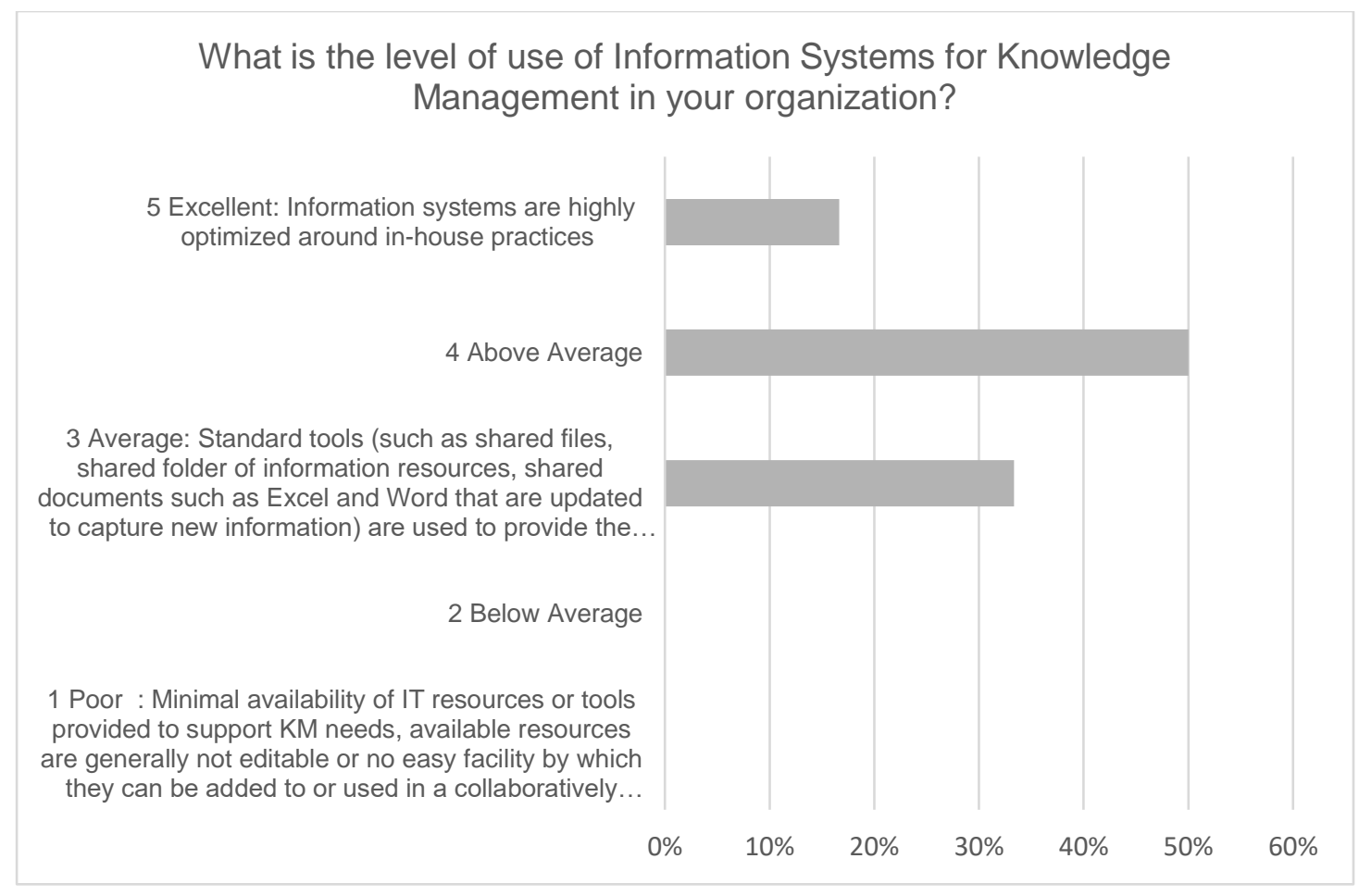

Figure 11 - level of information system use for knowledge management

\section{$\underline{\text { Communication vehicles }}$}

Question 5 was on understanding some of the communication vehicles that were being used. Email, skype and organisation website are the top 3 tools as depicted on Figure 12 below. 
Sharing of information including policies, processes and procedures

Question 6 was mainly on finding out the mechanisms or tools that were used to store and share the important organisation's documents like policies, processes and procedures. Figure 13 shows results to this question and email is the main tool that is used to share these important documents followed by training workshops.

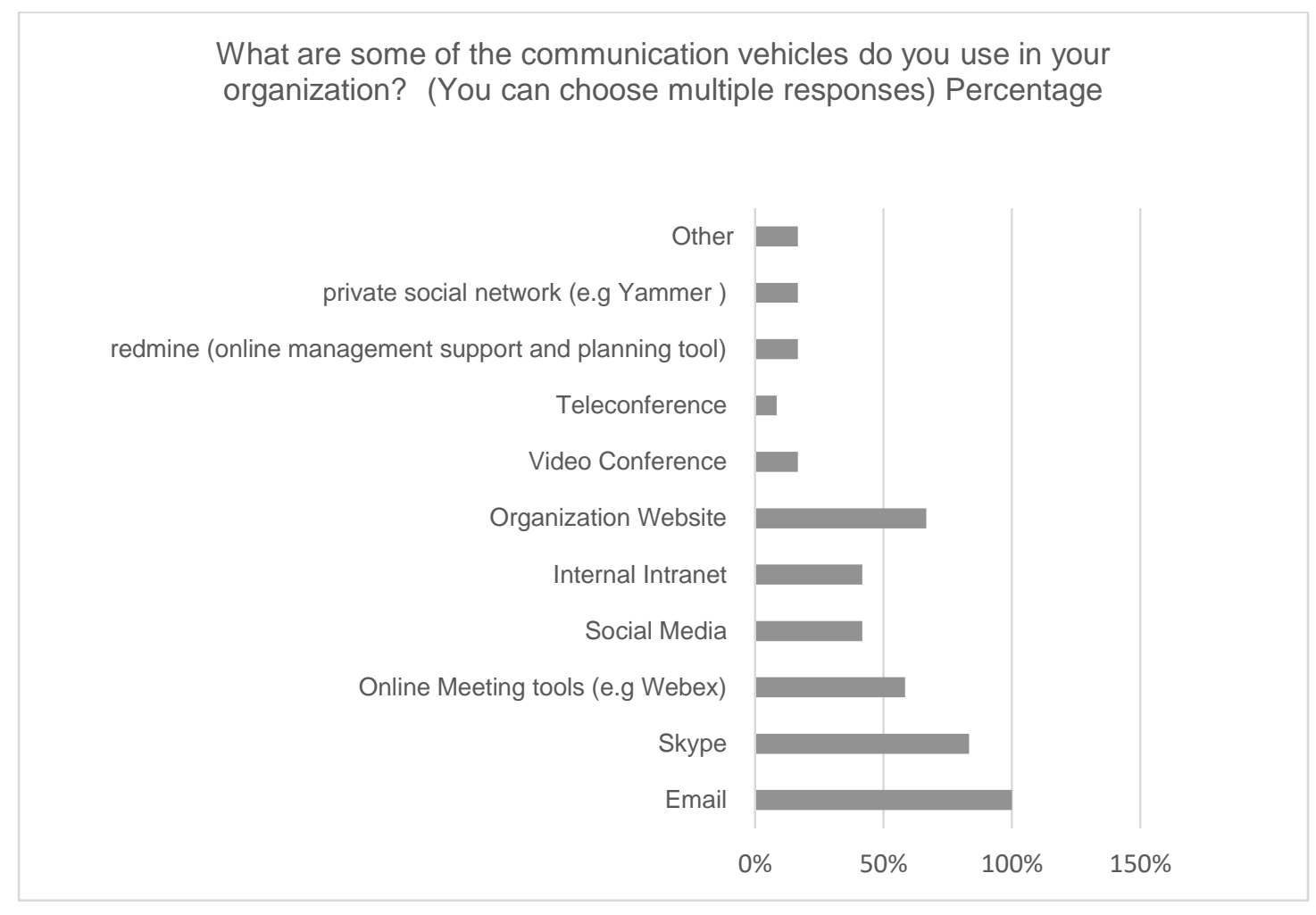

Figure 12 - Communication vehicles

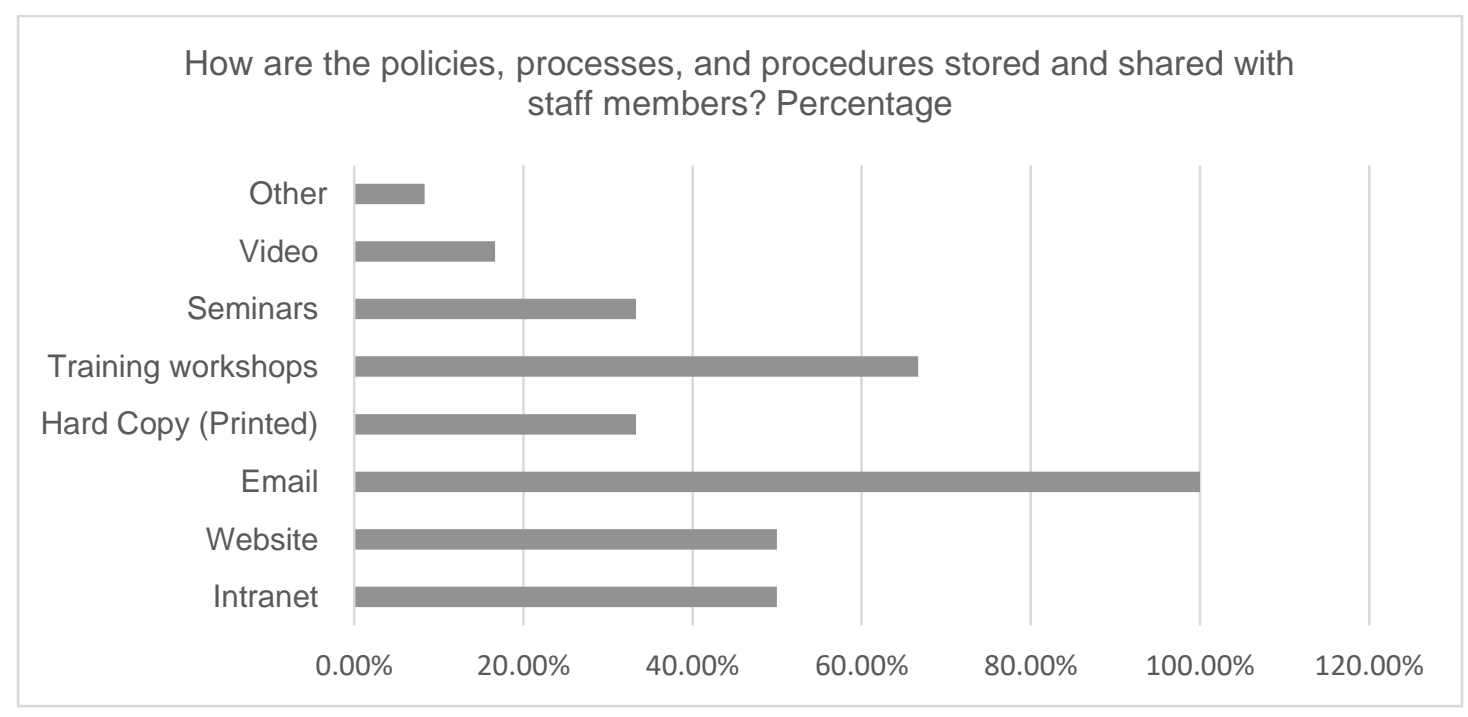

Figure 13 - sharing and storing policies, processes and procedures. 
Still on sharing of information, question 7 was about gauging the level of internal sharing of information within the organization. Figure 14 shows that majority of respondents were of the view that level of information sharing was acceptable. However, there were about $25 \%$ of respondents whose opinions were that level of information sharing was poor.

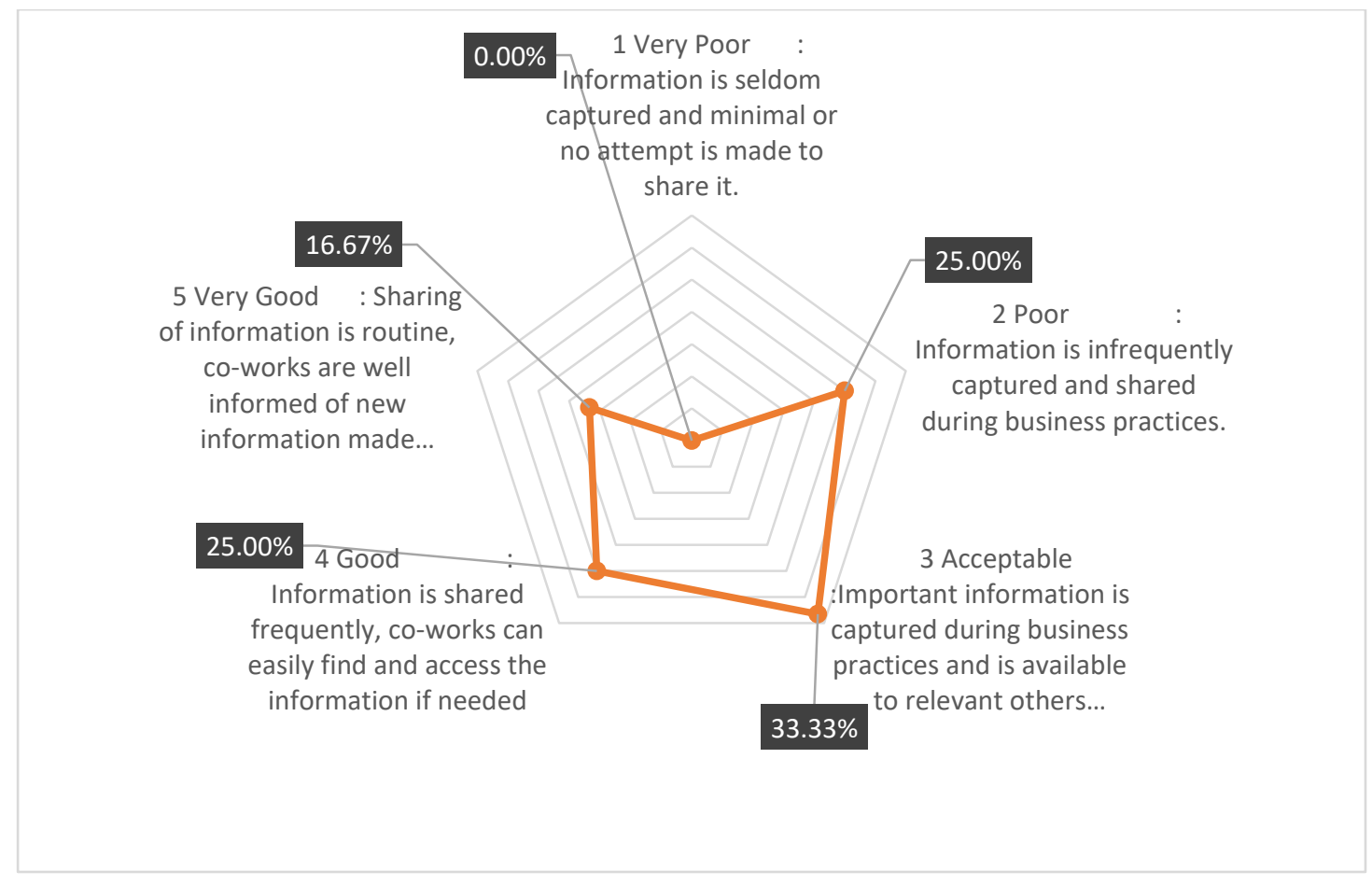

Figure 14 - level of information sharing

\section{Specialized Knowledge Management IT resources}

Over $58 \%$ of respondents were of the view that there were some specialized knowledge management related tools which were either under development or had been developed.

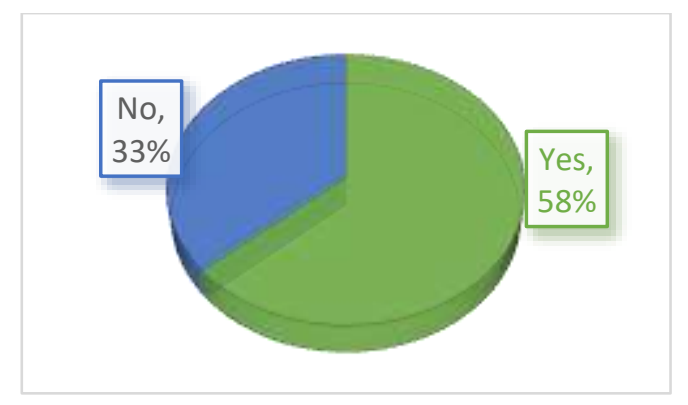

Figure 15 - Have any specialized IT resources or tools been developed - or under development - internally or by contract, to enhance KM practices in your organization? 
$\underline{\text { Incentives or formal recognition for disseminating knowledge }}$

Over $80 \%$ of respondents were of the opinion that there was no formal recognition or any incentives for disseminating knowledge as depicted in Figure 16.

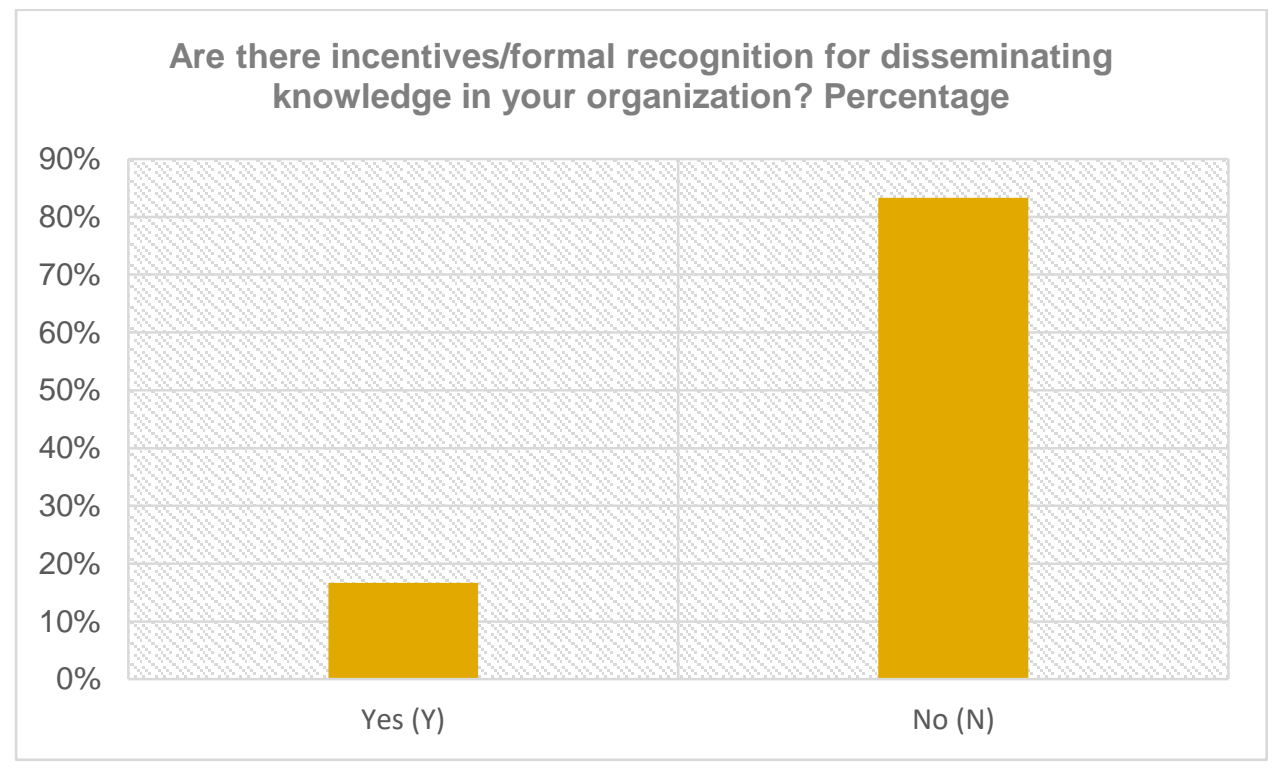

Figure 16 - incentives for disseminating knowledge

\section{Employees' competence on knowledge management}

$50 \%$ of respondents answered that employees' competence was below average as depicted in Figure 17 below.

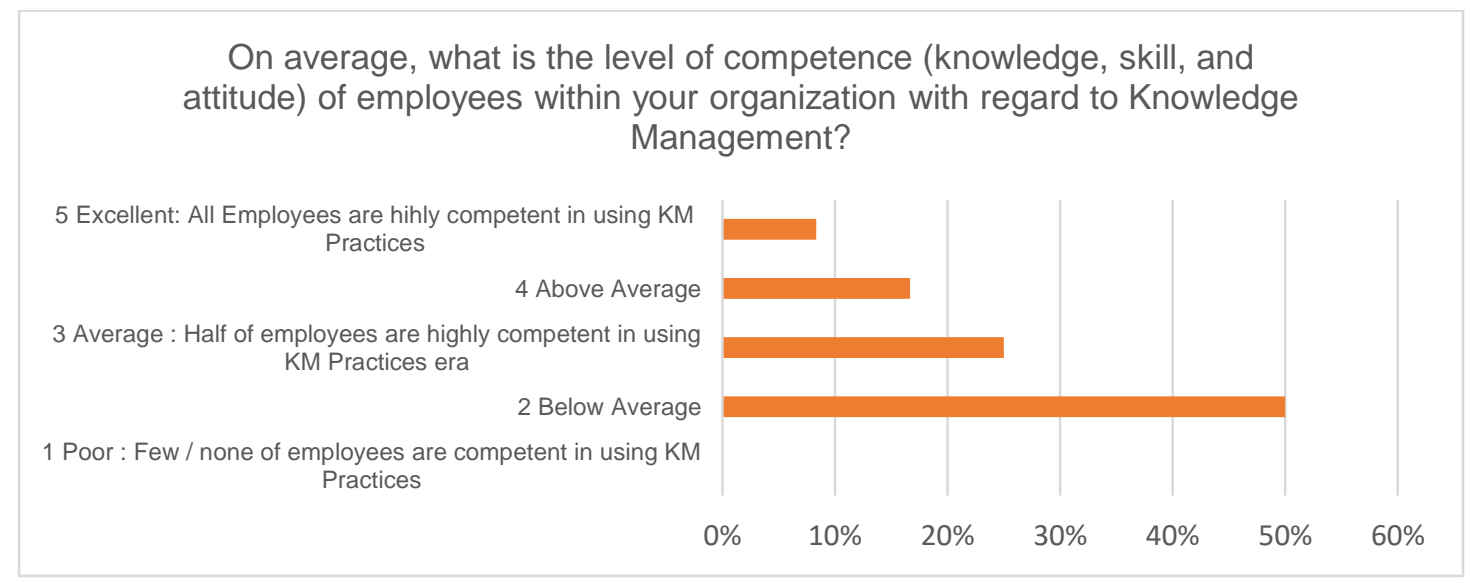

Figure 17 - employees' competence on knowledge management 


\section{Level of acquisition, storage and sharing of knowledge with other}

\section{stakeholders}

On the level of acquisition storage and sharing of knowledge with other stakeholders like beneficiaries, service providers, other departments, Head office, etc., majority of respondents answered that it was average as depicted by Figure 18.

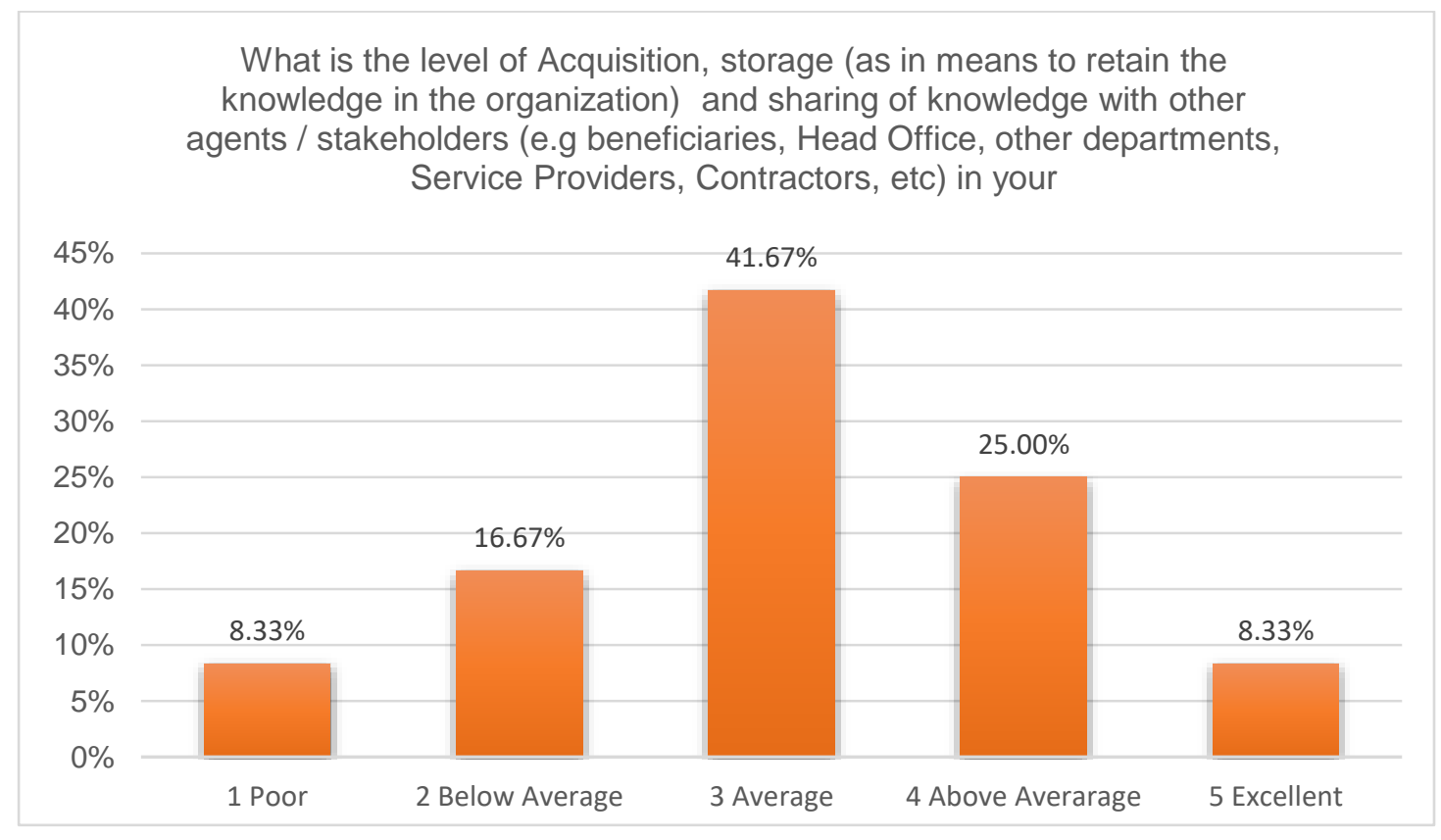

Figure 18 - level of knowledge acquisition, storage and sharing with stakeholders

Mode of knowledge with beneficiaries

Face to face training sessions scored the highest in terms of it being the tool that was used to share knowledge with beneficiaries. On the job training scored second. Focus group discussions and using email tool scored third. The other tools or modes of sharing knowledge with beneficiaries scored a bit lower as depicted in Figure 19.

\section{Additional comments}

The following list shows additional comments that respondents did concerning knowledge management practices in the organisation. The additional comments cover common themes around challenges like $\mathrm{KMS}$ (s) as a complex and not being fully implemented in the organisation. Another challenge mentioned is that there is no department responsible for knowledge management. Based on that information it can be gathered that there are ad-hoc knowledge managent practices in this organization 
and there is a need to move towards a more developed and documented Knowledge Management System.

i. The organization is starting to take strides to improve efforts towards knowledge Management and building institutional memory. There are at least two new systems being rolled out to address gaps in Knowledge management. The organization has also created or formed a group of KAIZEN (Continuous Improvement) sensei's to focus solely on improving and documenting business processes, as excellence in these processes is what will give this organization competitive advantage over other NGOs, especially taking into consideration the growing grants acquisition portfolio. At this stage, there is a growing number of staff who are beginning to embrace the importance of knowledge management, and the fact that it is one the strategic objectives of the organization, it makes it a very key area to be addressed as by vague of being in the strategy has the leadership backing.

ii. Knowledge Management has become an important aspect of the organization and this has been given prominence from the Global Centre down to the National Offices. The Global centre has developed WV Central which is a "one stop shop" and repository for every information required about the organization - Governance, Human Resource Management, Communities of Practice, Operations, Programme Quality and all Sectoral Programme. Another system established is HORIZON - An integrated system for the field with national strategy, DME, programme budgeting, sponsorship Registered Children monitoring and Child Well Being outcome reporting. It is designed for structured data. At the National Office Level, Knowledge Management is evident in Supply Chain Management Supplier database, Finance, HR. ShareNow Knowledge Management system has been developed where staff store their information under various sections - departments, programmes, projects etc. where others can easily access hence when a staff leaves the organization, accessing their project documents and reports is no longer a challenge.

iii. SOMETIMES THE PLATFORMS ARE TOO COMPLEX SO EVEN THOUGH THE INFORMATION IS THERE IT IS A CHALLENGE TO GET TO WHAT ONE NEEDS SPECIFICALLY. 
iv. The organization does not have a specific department which focuses on knowledge management but there is a Hub where the staff have access for any information, where one can have access to the systems and get a necessary knowledge. The information is always shared through emails and lots of training and meetings are done through WebEx for staff to have knowledge management.

v. In my view, knowledge capturing should be done when employees have gained a certain level of competence in a field, so when they leave, another person can pick up and move ahead.

vi. Good KM practices is important for any organization as it leads to high levels of productivity. Unfortunately, KM is rather poor in my organization. The typical scenario is that members train themselves, and gather the knowledge to accomplish tasks. Then when they leave, all that knowledge is often undocumented and is lost to the organization. This causes new members to frequently 'reinvent the wheel' for problems that have already been solved!

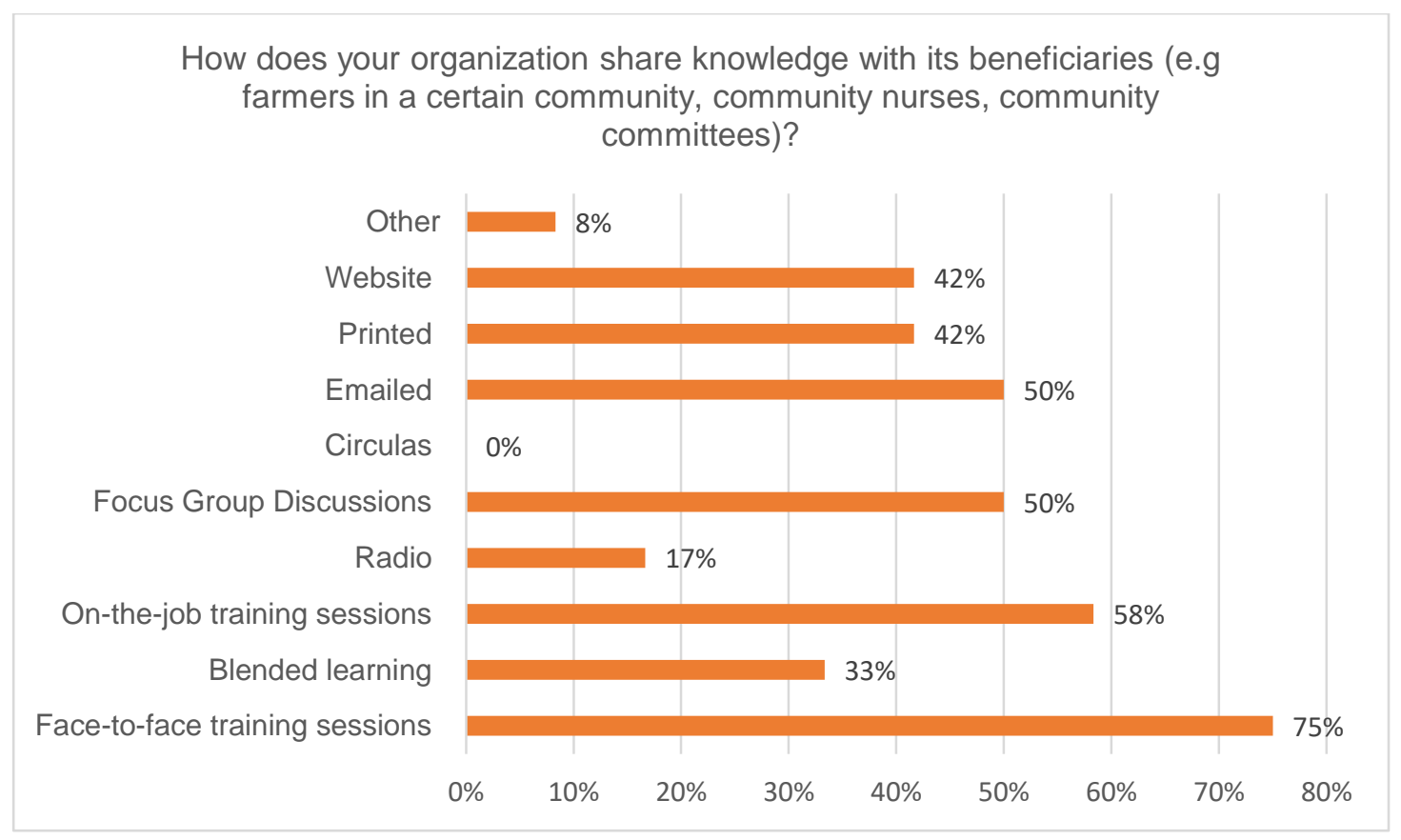

Figure 19 - sharing knowledge with beneficiaries. 


\subsection{Concept exploration}

Under concept exploration phase, interviews with employees and exploration of the literature were used to come up with requirements for the proposed system.

\subsubsection{Interviews with employees}

The interviews were conducted with employees of the organisation under this study to understand functions and capabilities that a COP support website should have. Furthermore, an expert from a software development company was also interviewed just to make sure that some of other key requirements can be included. Table 1.7 depicts the results of the interviews. Items highlighted in grey were suggested by most of the interviewees and were prioritised as critical requirements.

Table 1.7: Requirements gathering- interviews with employees

\begin{tabular}{|c|c|c|c|}
\hline Employee 1 & Employee 2 & Employee 3 & $\begin{array}{l}\text { Employee 1(Website } \\
\text { Development Company) }\end{array}$ \\
\hline 1. Facilitate discussions. & 1. Blogging & $\begin{array}{l}\text { 1. The system should } \\
\text { be Interactive. }\end{array}$ & $\begin{array}{l}\text { 1. The system should be } \\
\text { Generic }\end{array}$ \\
\hline $\begin{array}{l}2 . \quad \text { There should be } \\
\text { ethics in terms of system } \\
\text { usage) }\end{array}$ & $\begin{array}{l}\text { a. Discussions (Topics } \\
\text { and Comments) }\end{array}$ & $\begin{array}{l}\text { 2. The system } \\
\text { should have a Flash } \\
\text { player so that it can } \\
\text { give one different } \\
\text { feedback based on } \\
\text { different inputs. }\end{array}$ & $\begin{array}{l}\text { a. Integrate Single } \\
\text { groups }\end{array}$ \\
\hline 3. Easily accessible. & $\begin{array}{l}\text { 2. Upload and share } \\
\text { documents }\end{array}$ & $\begin{array}{l}\text { 3. The system } \\
\text { has to be User } \\
\text { friendly }\end{array}$ & $\begin{array}{l}\text { b. Interactions between } \\
\text { different groups of users. }\end{array}$ \\
\hline a. Easy login facility & $\begin{array}{l}\text { 3. Creation, and editing } \\
\text { Individual profiles. }\end{array}$ & $\begin{array}{l}\text { 4. The system's } \\
\text { Layout should be } \\
\text { quite easy to } \\
\text { understand. }\end{array}$ & $\begin{array}{l}\text { 2. Handle files of different } \\
\text { types. }\end{array}$ \\
\hline \multirow[t]{6}{*}{$\begin{array}{l}\text { 4. Light on bandwidth } \\
\text { consumption meaning } \\
\text { that is should run well in } \\
\text { slow connections. }\end{array}$} & $\begin{array}{l}\text { 4. Capability of breaking } \\
\text { information into groups } \\
\text { so as to increase search } \\
\text { ability. }\end{array}$ & $\begin{array}{l}5 . \quad \text { It is important } \\
\text { to know what kind of } \\
\text { information the } \\
\text { website is passing. }\end{array}$ & $\begin{array}{l}\text { a. Upload files of different } \\
\text { types, such as videos into } \\
\text { the system }\end{array}$ \\
\hline & 5. user registration & $\begin{array}{l}\text { 6. The system } \\
\text { should also FAQs, } \\
\text { Contact us, }\end{array}$ & $\begin{array}{l}\text { b. Restriction in terms of file } \\
\text { sizes that can be uploaded. }\end{array}$ \\
\hline & $\begin{array}{l}\text { 6. The system should } \\
\text { encompass } 8 \text { Golden } \\
\text { rules of } \mathrm{HCl} \text { : }\end{array}$ & & $\begin{array}{l}\text { 3. The system should be } \\
\text { light, }\end{array}$ \\
\hline & a. Consistency & & $\begin{array}{l}\text { a. It should perform well } \\
\text { when one is in remote areas } \\
\text { where there is low Internet } \\
\text { speed. }\end{array}$ \\
\hline & b. Simplicity & & $\begin{array}{l}\text { b. It should also be able } \\
\text { to run in low end devices. }\end{array}$ \\
\hline & $\begin{array}{l}\text { c. Use of less number of } \\
\text { colors. }\end{array}$ & & $\begin{array}{l}4 . \quad \text { End users of the } \\
\text { system should have different } \\
\text { access rights }\end{array}$ \\
\hline
\end{tabular}




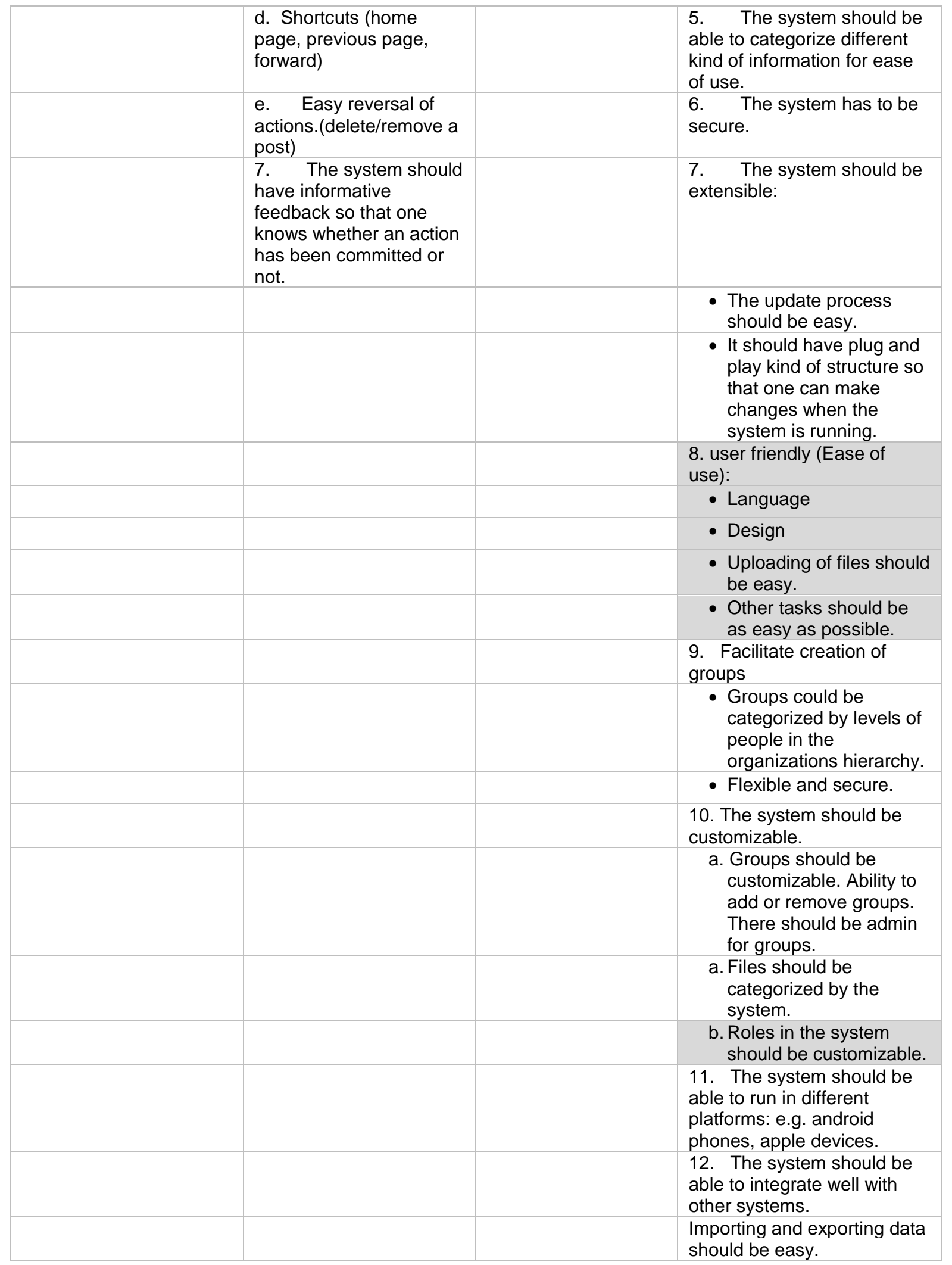




\subsubsection{Requirements gathered from the literature}

Requirements were gathered from the literature in order to bring in best practices and consider other things other researchers have used and recommend. Such requirements are elaborated in the literature section under heading number 2.5 . The following is the summary of such requirements:

R1. Facilitate asynchronous communication,

R2. Facilitate synchronous communication,

R3. RSS Feeds,

R4. Customizable,

R5. Easily navigated and searched.

\subsubsection{Combination of requirements from interviews and literature}

It was necessary to combine requirements gathered through interviews and those gathered from the literature. On top of combining the requirements, it was critical to prioritise the requirements. The requirements that were prioritised were the ones that were mentioned by multiple people in the survey and those requirements that were strongly emphasised by different articles and journals. The following is a list of final prioritised functional requirements.

F1. Asynchronous communication: The system shall facilitate communication through discussion forums.

F2. Synchronous communication: COP members shall be able to communicate in real time using CHAT functionality.

F3. Uploading of files: The system shall have a capability of uploading and sharing of different files.

F4. Tagging: Content tagging to improve search ability.

F5. Groups: Configuration and creation of collaboration groups

F6. RSS Feeds: Capability to create RSS feeds.

F7. Profile: A COP member shall be able to create and maintain his or her own profile.

\subsubsection{Test Cases' development}

The different test cases were developed to test the requirements that were covered in section 4.2.3. These types of tests are called functional tests because they assesses how the target-of-test functions execute the required use case as intended [5]. There 
are other non-functional characteristics that should still be taken care of like security, and performance of the system [5] [63]. Test case 1.1 and 1.2 speak to security requirement. Furthermore, test case 9 focuses on system performance.

\begin{tabular}{|c|c|c|c|}
\hline Test Number & Description & Functions Checked & $\begin{array}{l}\text { Requirements } \\
\text { Tested }\end{array}$ \\
\hline Test Case 1.1 & Login Functionality & $\begin{array}{l}\text { Test the Login } \\
\text { functionality of the COP } \\
\text { website using correct } \\
\text { login credentials. }\end{array}$ & Security. \\
\hline Test Case 1.2 & Login Functionality & $\begin{array}{l}\text { Test the Login } \\
\text { functionality of the COP } \\
\text { website using incorrect } \\
\text { login credentials. }\end{array}$ & Security. \\
\hline Test Case 2 & $\begin{array}{l}\text { Creation of an } \\
\text { event }\end{array}$ & $\begin{array}{l}\text { Creation of an event } \\
\text { functionality in the COP } \\
\text { website. }\end{array}$ & $\begin{array}{l}\text { R1. Asynchronous } \\
\text { communication. }\end{array}$ \\
\hline Test Case 2.1 & $\begin{array}{l}\text { Creation of an } \\
\text { event (date in the } \\
\text { past) }\end{array}$ & $\begin{array}{l}\text { Creation of an event } \\
\text { functionality in the COP } \\
\text { website. (date in the } \\
\text { past) }\end{array}$ & $\begin{array}{l}\text { R1. Fault condition: } \\
\text { setting an event in the } \\
\text { past }\end{array}$ \\
\hline Test Case 3 & Creation of a group & $\begin{array}{l}\text { Test creation of a group } \\
\text { in the COP website }\end{array}$ & $\begin{array}{l}\text { R1. Groups: } \\
\text { Configuration and } \\
\text { creation of } \\
\text { collaboration groups }\end{array}$ \\
\hline Test Case 4 & $\begin{array}{l}\text { Creation of a basic } \\
\text { page }\end{array}$ & $\begin{array}{l}\text { Test creation of a basic } \\
\text { page }\end{array}$ & $\begin{array}{l}\text { R1. Asynchronous } \\
\text { communication. }\end{array}$ \\
\hline
\end{tabular}




\begin{tabular}{|c|c|c|c|}
\hline Test Case 4.1 & $\begin{array}{l}\text { Creation of a basic } \\
\text { page (upload } \\
\text { wrong image type) }\end{array}$ & $\begin{array}{l}\text { Test creation of a basic } \\
\text { page (upload wrong } \\
\text { image type) }\end{array}$ & $\begin{array}{lr}\text { R1. Fault } & \text { condition: } \\
\text { uploading } & \text { wrong } \\
\text { image type. } & \end{array}$ \\
\hline Test Case 5 & Creation of a profile & Test creation of a profile & $\begin{array}{l}\text { R4. Profile: A COP } \\
\text { member shall be able } \\
\text { to create and maintain } \\
\text { his or her own profile. }\end{array}$ \\
\hline Test Case 6 & $\begin{array}{l}\text { Creation of a new } \\
\text { topic }\end{array}$ & $\begin{array}{l}\text { Test creation of a new } \\
\text { topic }\end{array}$ & $\begin{array}{l}\text { R1. Asynchronous } \\
\text { communication. }\end{array}$ \\
\hline Test Case 7 & CHAT functionality & $\begin{array}{l}\text { Test real time } \\
\text { communication using } \\
\text { CHAT }\end{array}$ & $\begin{array}{l}\text { R2. Synchronous } \\
\text { communication. }\end{array}$ \\
\hline Test Case 8 & RSS Feeds & Test RSS Feeds & R3. RSS Feeds. \\
\hline Test Case 9 & $\begin{array}{l}\text { Pages Loading } \\
\text { time }\end{array}$ & $\begin{array}{l}\text { How long pages take to } \\
\text { load }\end{array}$ & System performance. \\
\hline
\end{tabular}

The next section focuses on the prototyping of the COP website that is a support tool taking into account the requirements that have been gathered and defined in Chapter 4. 


\section{Prototype Design}

From the requirements developed in chapter 4 this chapter focuses on developing a COP support website, this website is referred to as the Mafcop (Mafereka's Community of practice). The Mafcop is intended as a general-purpose site that can be adjusted to specific company needs.

Different design aspects were drafted, tested and refined through review process with an expert. These include layered architecture, website navigation diagram, key use case diagrams, sequence diagrams for key functions.

\subsection{Layered architecture COP support website}

A layered architecture of a COP support website was developed as depicted is Figure 20 below. The architecture has four layers namely, system support, application functionality, user interface management, authentication and authorization and user interface. What is key is the fact that all the prioritized functional requirements were catered for in the architecture.

\subsection{Website navigation diagram}

A website navigation diagram which gives one an idea of how to navigate around the presentation components of a website is depicted by Figure 21. The COP website has major tabs being Profile, group, discussion, resources, and search function. Help tab is mainly for guiding users on different topics with regard to using the website. 


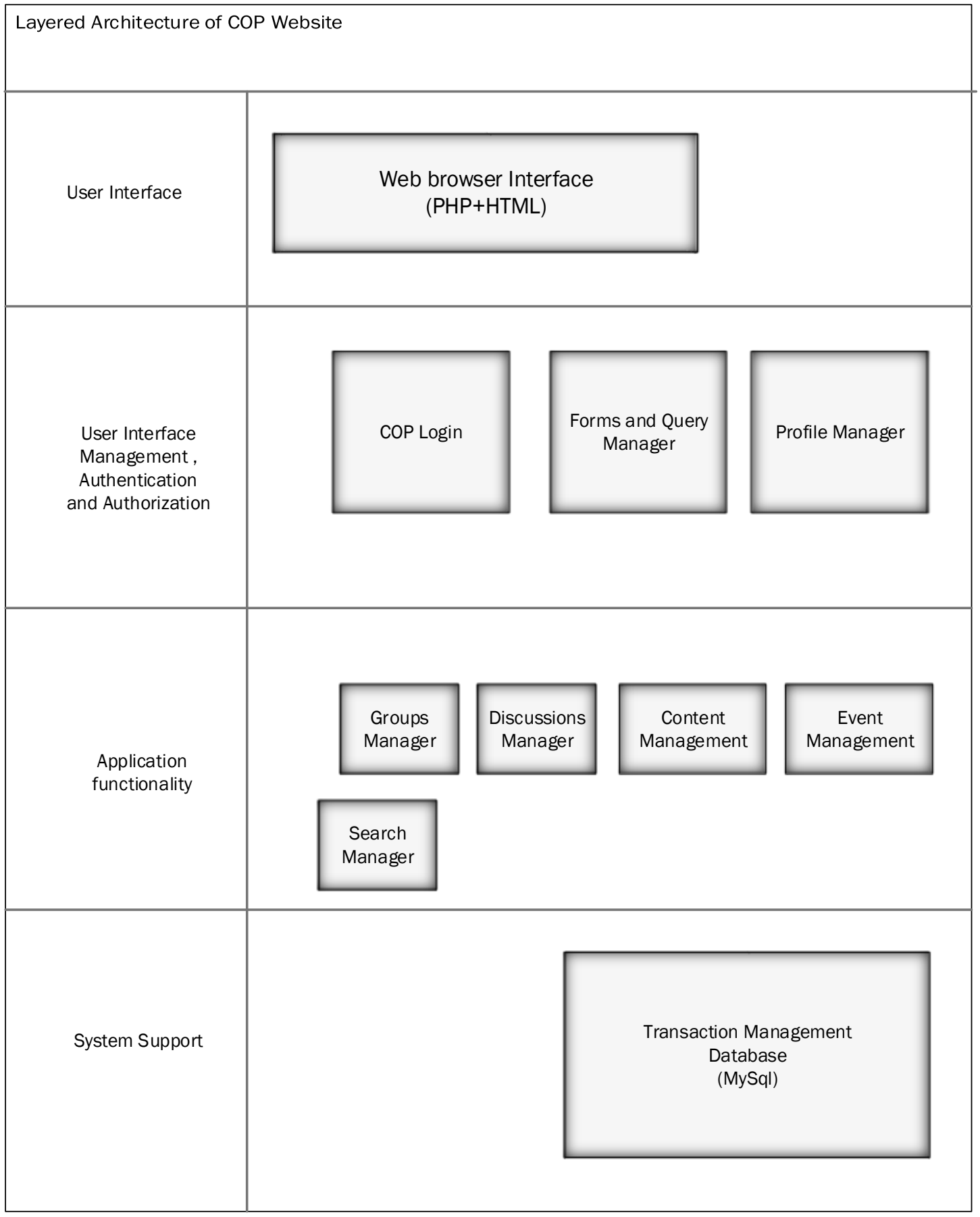

Figure 20- Layered architecture of a COP support Website 


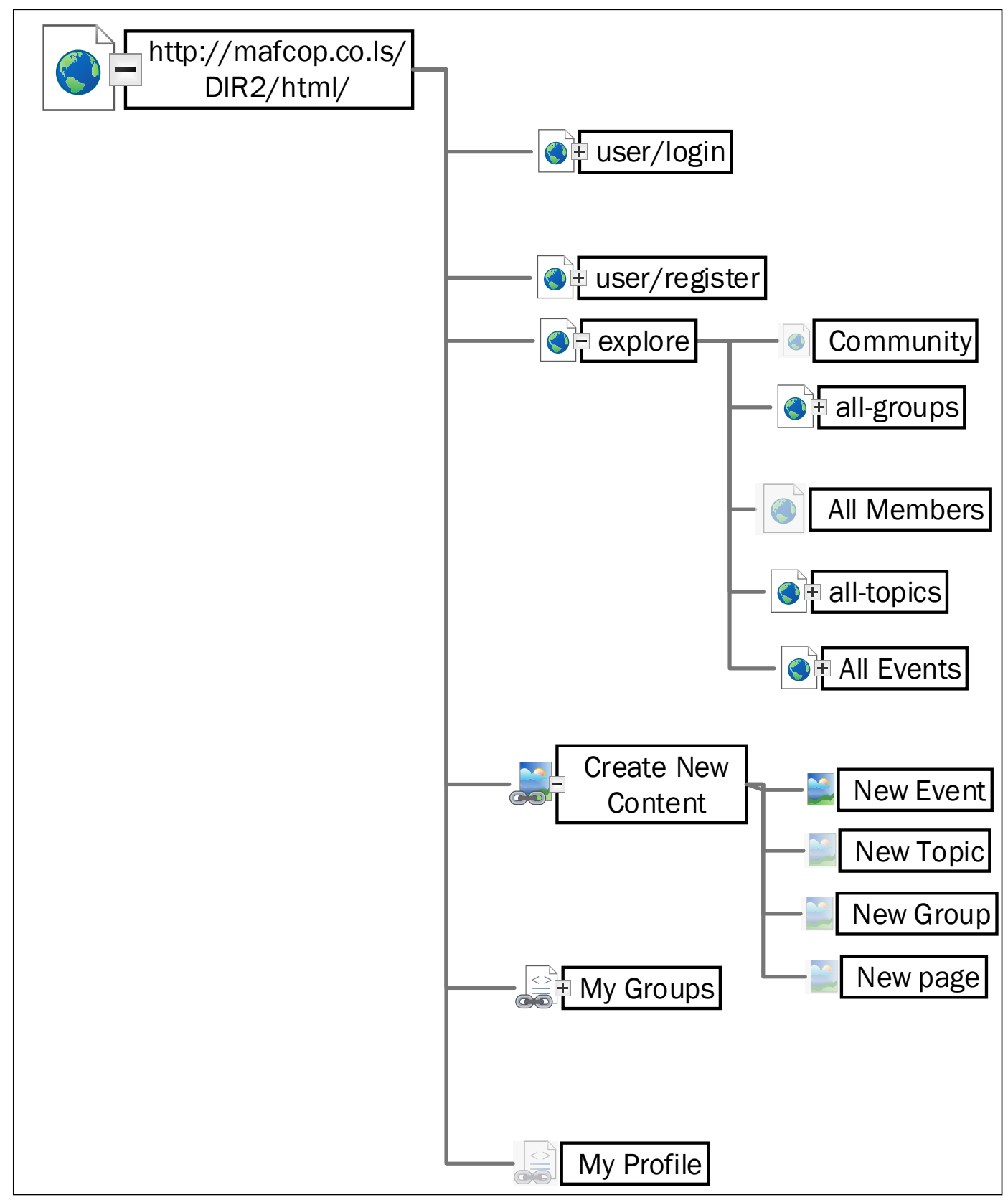

Figure 21 - COP Website navigation diagram (automatically generated from Drupal Mafcop website using Microsoft Visio)

\subsection{Use case diagrams}

This section focuses on use case diagrams which are used to model business processes that could be performed in the prototype system. The subsections here are named according to the role that will interact with the use cases. 


\subsubsection{Anonymous user}

Use case diagram for an anonymous user is depicted in Figure 22. It depicts what an anonymous user can do in the system. Anonymous user can only view pubic content and can register to be the member of the COP Website and the request can be accepted or rejected by the Site Manager.

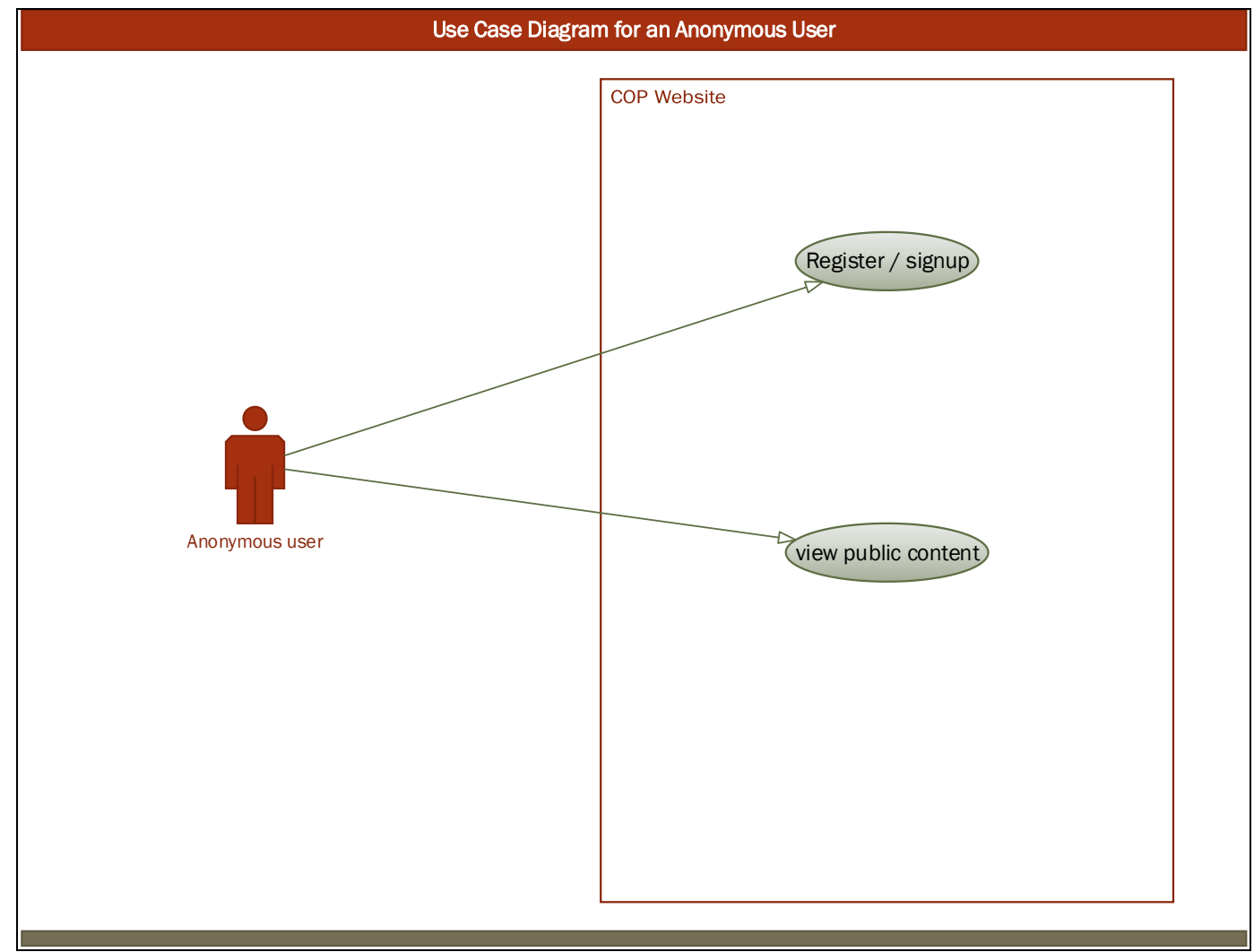

Figure 22 - Use case for anonymous user

Registration or signup task enables a non-authenticated user to register to become the member of the COP website. See section 5.4.1 which shows sequence diagram for registration. View public content task enables an authenticated user to be able to view content that has been published in the COP website either through navigating to different sections of the website or through search functionality. Section 5.4 .2 depicts a sequence diagram for viewing public content.

\subsubsection{Authenticated COP User}

Use case diagram for a standard COP User is depicted in Figure 23. It depicts what an authenticated COP User can do in the system. The Authenticated COP user has 
registered for the COP website. Furthermore, he or she can post comments, edit and create new content, events and groups.

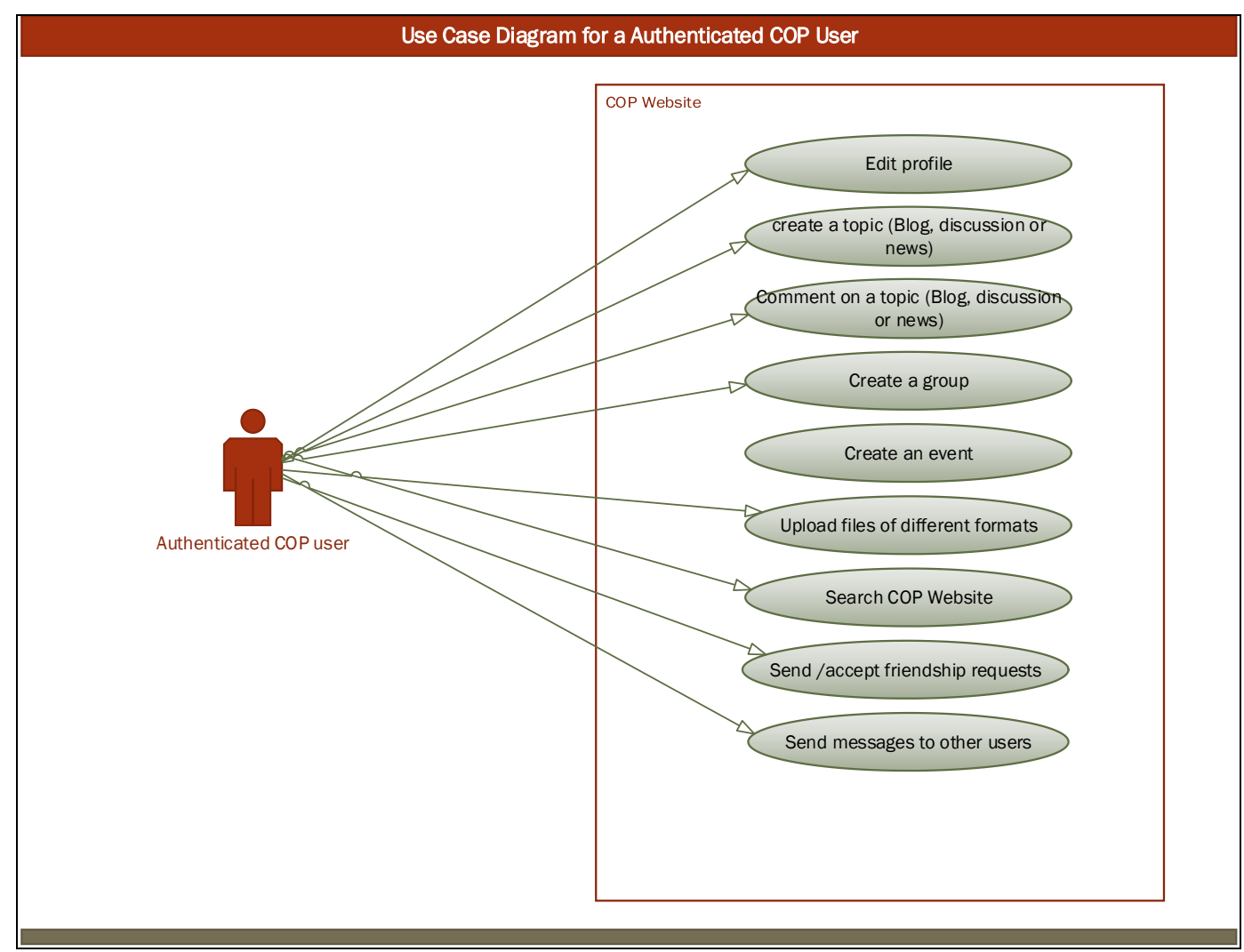

Figure 23 - Use Case diagram for a standard COP User

Furthermore, an authenticated user can search the website for content, send or accept friendship requests from other authenticated users. Such a user can also send messages to other authenticated users.

\subsubsection{Content Manager}

Content Manager is responsible for daily operation of the COP Website in terms of deleting and un-publishing any content, posts, comments and groups. Use case diagram for a Content Manager is depicted in Figure 24. It depicts what a Content manager can do in the system. 


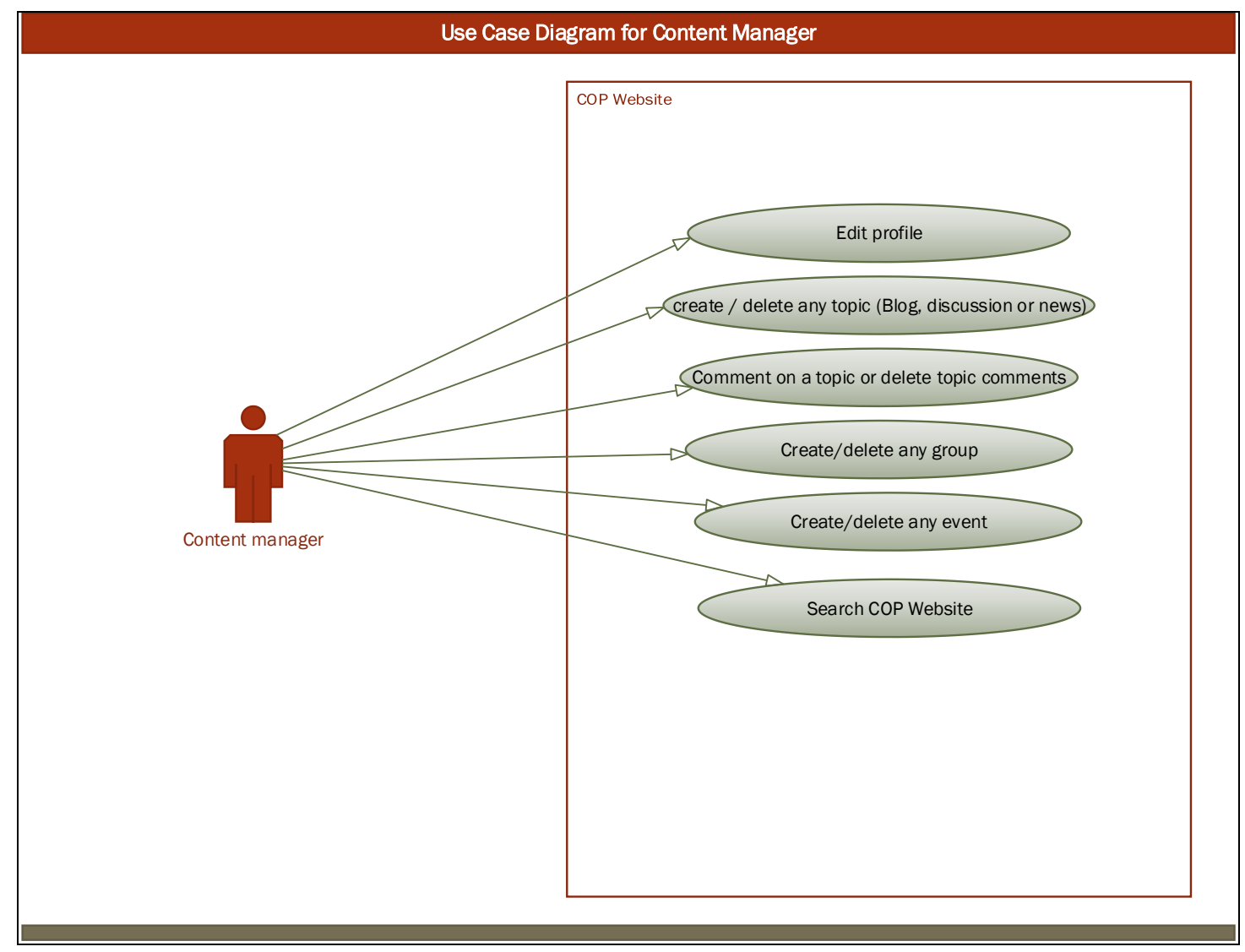

Figure 24 - Use case diagram for Content Manager

\subsubsection{GroupEvent Manager}

Group or Event Manager can do what an authenticated user can do in the system and he or she automatically becomes a group or event manager after creating a group or an event. Use case diagram for a Content Manager is depicted in Figure 25. It depicts what a Group or Event manager can do in the system. The GroupEvent Manager can set-up a group and administer it in terms of adding or removing members of the group. He or she comes up with the purpose of the group. He or she can create an event, load all the details of the event like date, time, venue, agenda, and content that will be needed for that event. Then he or she can invite other members to that event.

\subsubsection{Site manager}

The Site Manager is in charge of the configuration and management of the COP website. Furthermore, he or she is responsible for management of all user accounts. Use case diagram for a Site Manager is depicted in Figure 26. The Site Manager is a super-user with read and write capabilities. 


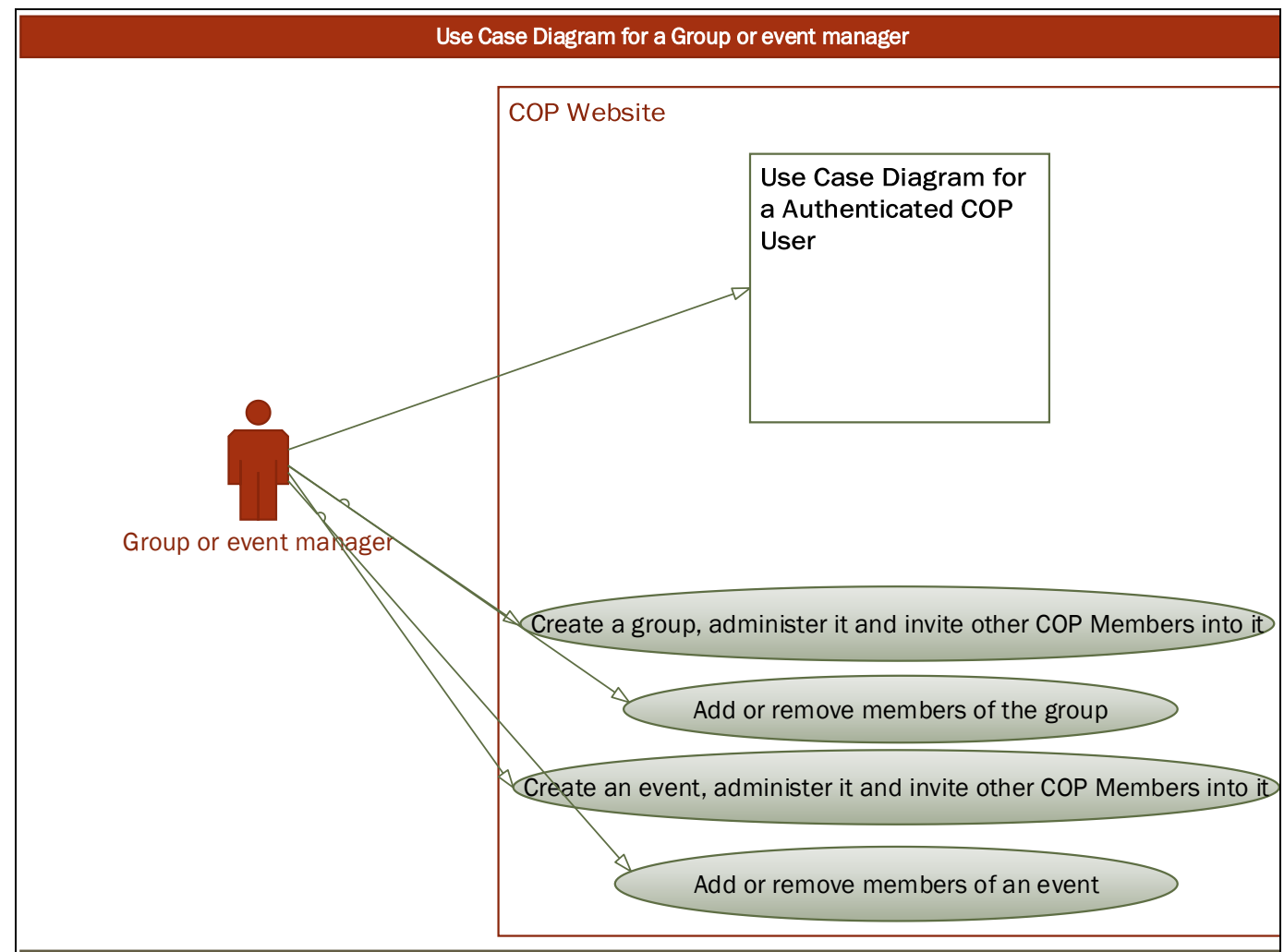

Figure 25 - Group Event Manager

Use Case Diagram for a Site manager

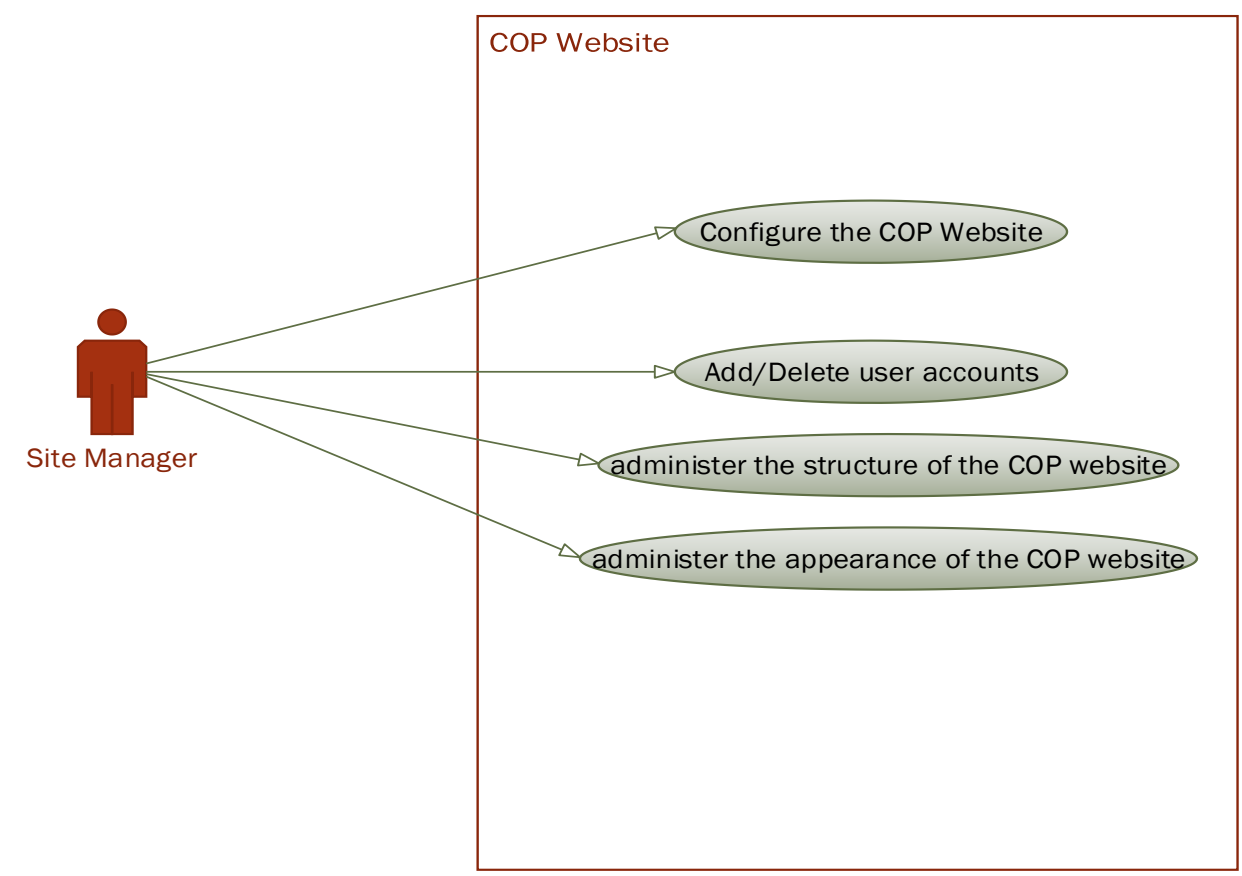

Figure 26 - Use case diagram for a Site Manager 
The next section focuses on the Sequence diagrams for key functions that have been captured by different Use Case diagrams. 


\subsection{Sequence diagrams for key functions.}

These are all model scenarios where there are no faults. See section5.4.3 for sequence diagrams that model a number of likely fault conditions.

\subsubsection{Registration}

This section covers sequence diagram for registration of a new user into the COP website. The user will have to click on the register button and a form for registration will be displayed. She will then fill-in her information and click register. The success message will be displayed and an activation email will be send to her email address. She will click on the link contained in the activation email to activate the account. Figure 27 depicts the series of actions in the registration process.

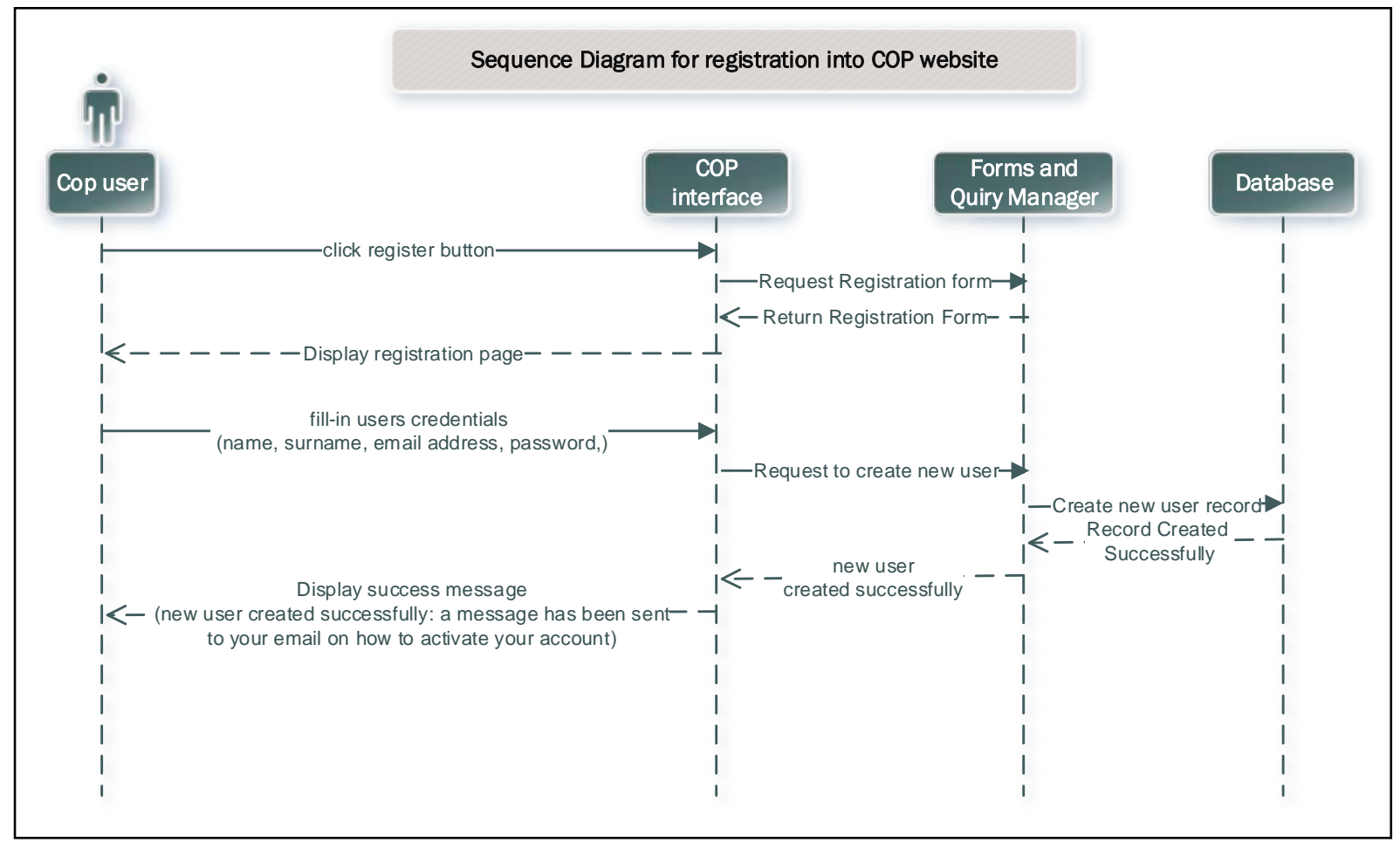

\section{Figure 27 - Registration into COP website}

The registration process is completed through following a link that is automatically send to the user upon registration

\subsubsection{Creation of group}

A group allows a set of users to share ideas and organize events with each other around one specific subject. It can be seen as a smaller communities within a bigger 
community. In each group one can find Stream (activities in a group), Events (events organised in a group), Topics (topics created in a group and Members of a group.

Figure 28 shows a sequence diagram for creation of a group activity in the COP website by an Authenticated user. It also contains a sub-sequence diagram for creation of a new topic within a group.

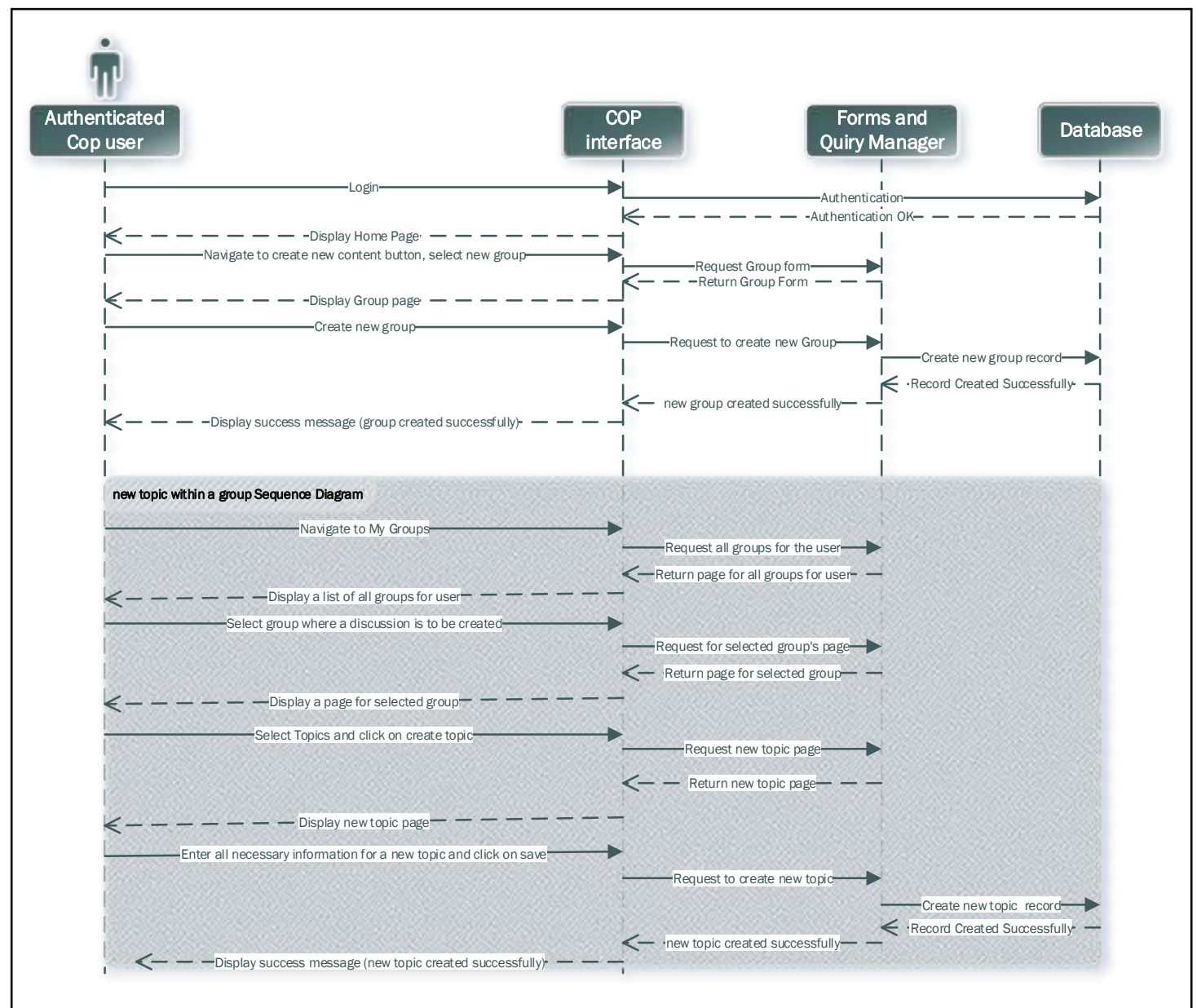

Figure 28 - Sequence diagram for creation of a new group in a COP Website

\subsubsection{Edit a user profile}

It is crucial for a COP website user to be able to edit his or her profile. The profile has the following fields that can be edited by the user: firstname, last name, nickname, profile image, function, address, phone number, self-introduction, interests and expertise.

Figure 29 portrays a sequence diagram for editing of a user profile. 


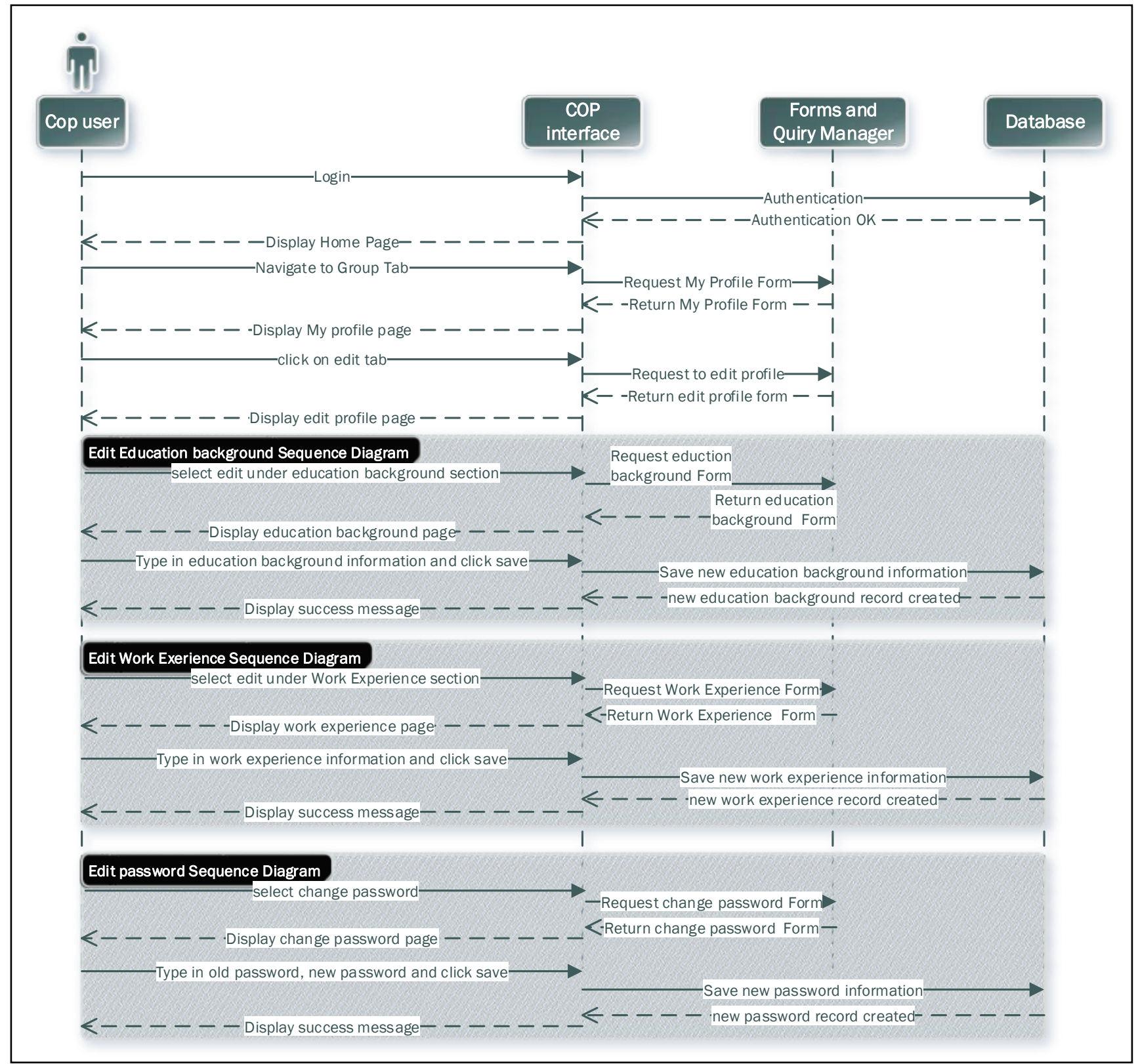

Figure 29 - Sequence diagram for editing of a user profile

\subsubsection{Creation of a new topic}

Topic is a type of content which allows users to share information or organise discussions. It can be a piece of news, blog, document or a discussion. Figure 30 depicts a sequence diagram for creation of a new topic in the COP website by an authenticated user. 


\subsubsection{Creation of a new event}

Events allow users to organise, discuss, and join activities. Events can be placed inside or outside a group. Figure 31 annotates a sequence diagram for creation of a new event in the COP website.

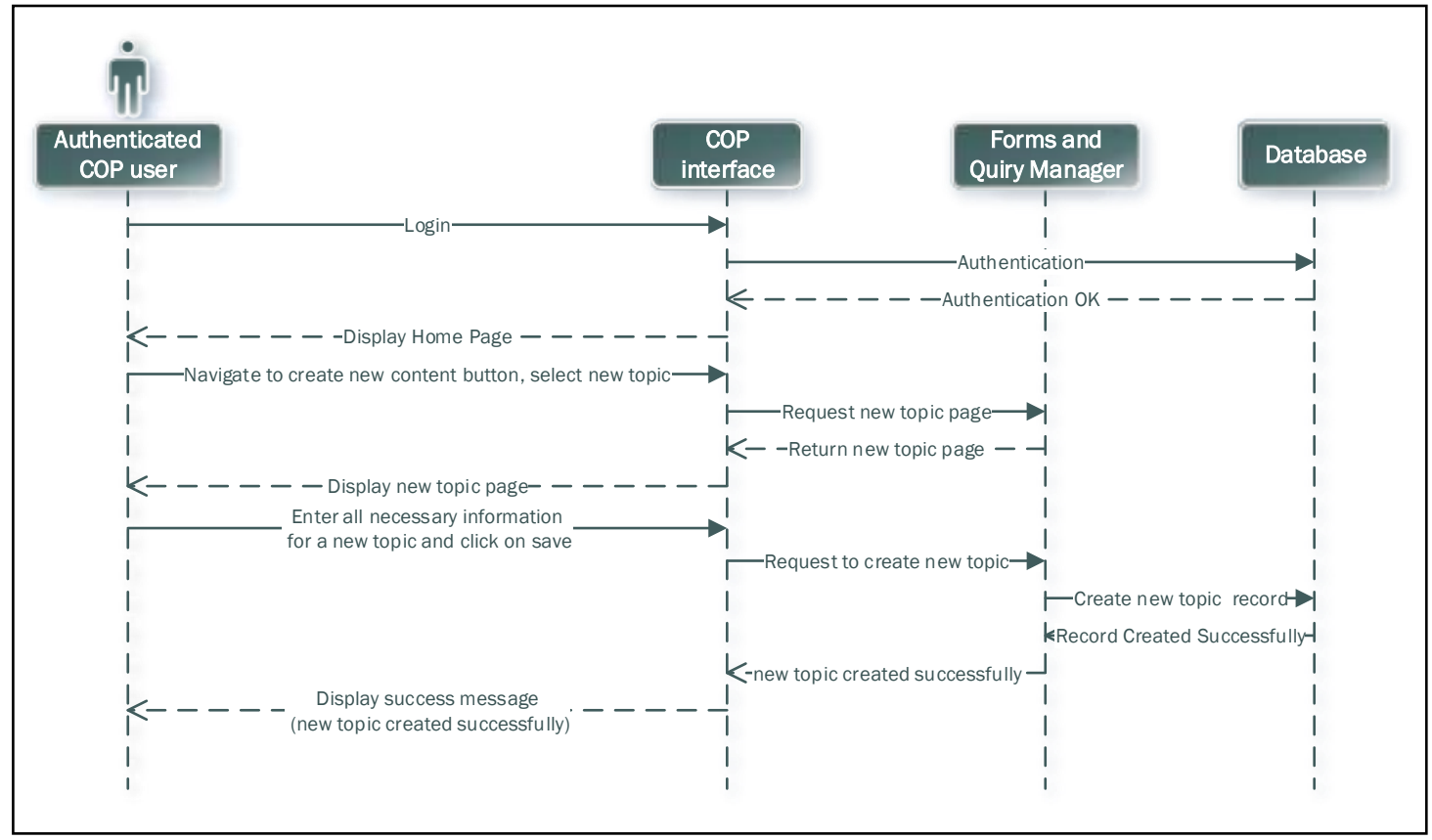

Figure 30 - Sequence diagram for creation of a new topic

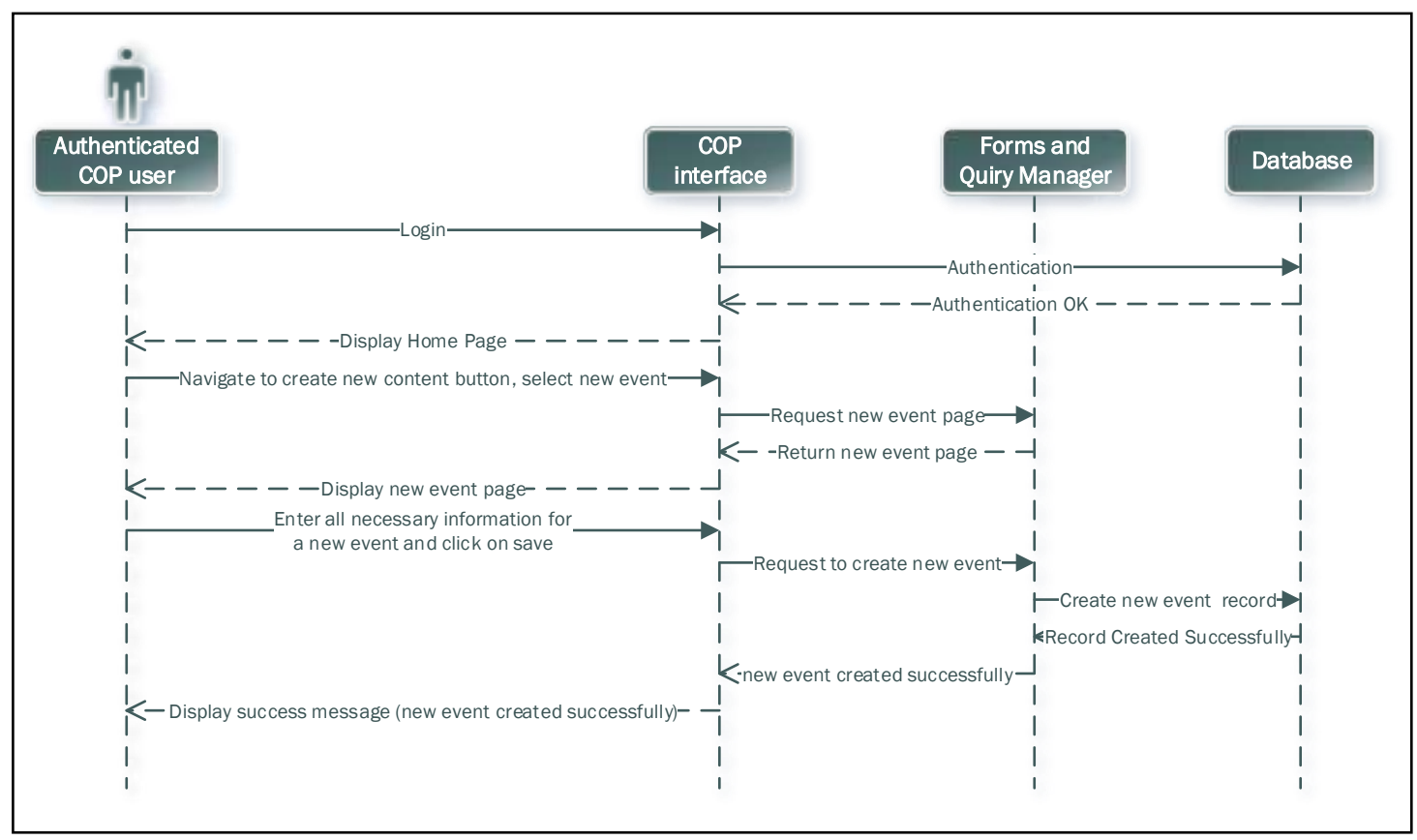

Figure 31 - Sequence diagram for creation of a new event 


\subsubsection{Creation of a new page}

It is crucial for an Authenticated user to be able to create a basic page. Basic pages can be used in many ways. For example, they can be used to create a contact page (potential members can contact community management for more information). Furthermore, they can be used to create information pages where users can read all about the organization behind the community. Figure 32 paints a sequence diagram for creating a new page.

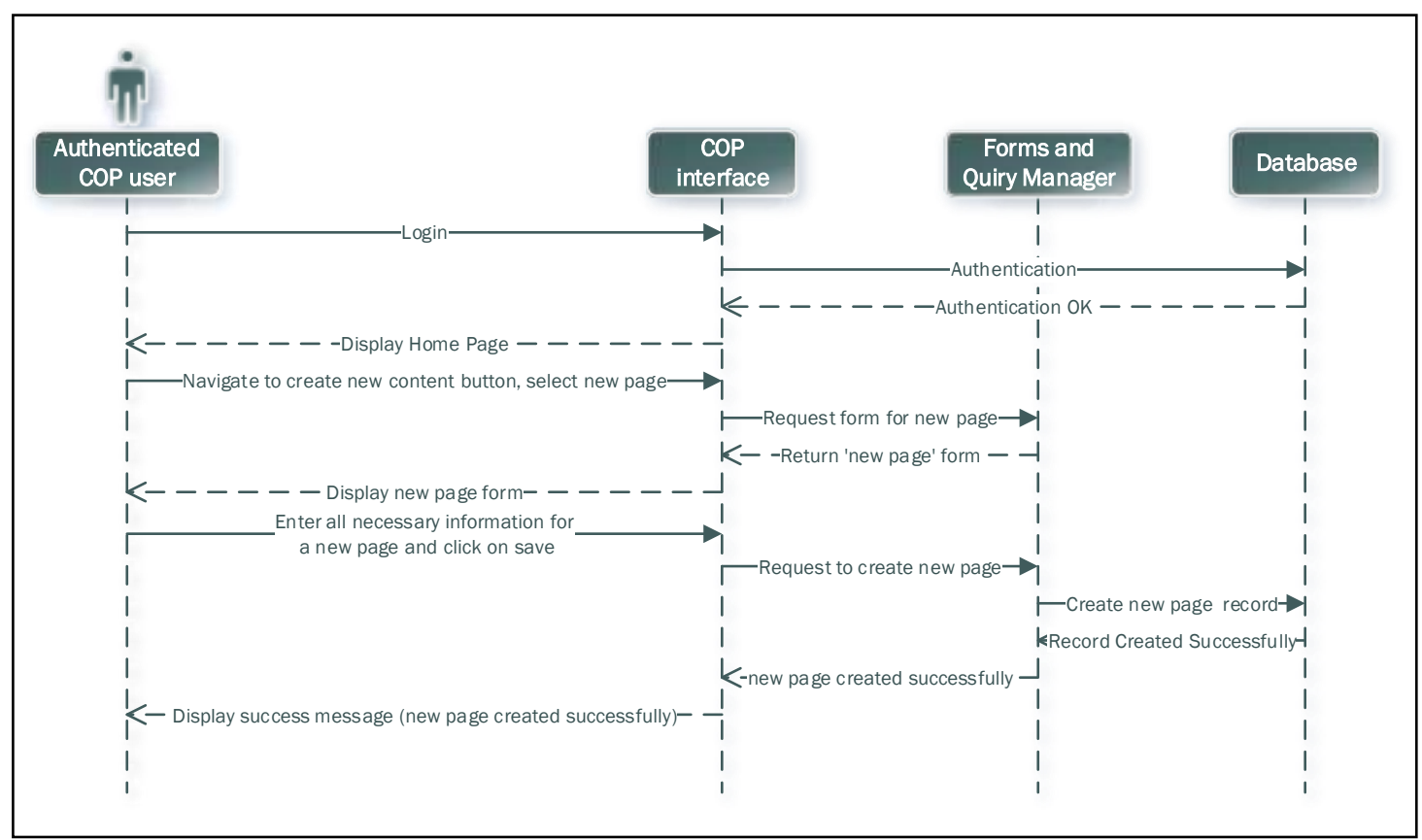

Figure 32 - Sequence diagram for creating a new page.

\subsubsection{Sequence diagrams with fault conditions}

This section covers sequence diagrams with fault conditions. This is important to make sure that the system does not crash when incorrect inputs are entered into the system [63]. Furthermore, it is key for the user to receive feedback if such fault conditions are discovered. The fault conditions that are catered for in this section are
a. Incorrect credentials used to login into the COP website.
b. Past date used to create an event.
c. Uploading unsupported image type. 


\subsubsection{Sequence diagram invalid login into COP website}

The sequence diagrams shows the series of steps that are going to be followed when invalid login credentials are entered in the COP website. Figure 33 displays this sequence diagram.

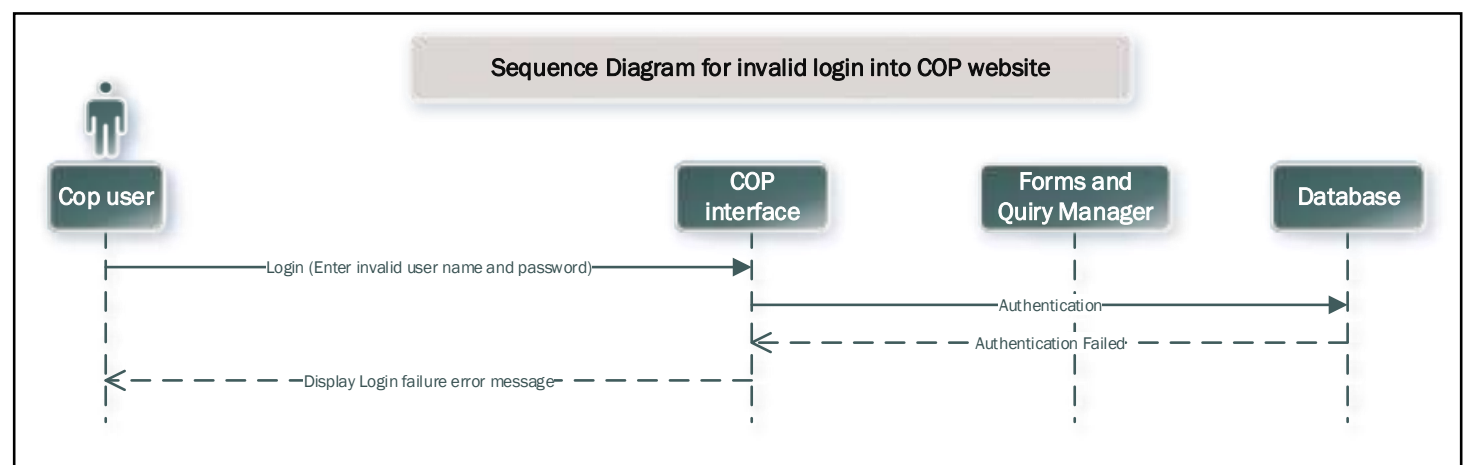

Figure 33 - sequence diagram for invalid login into COP website

\subsubsection{Sequence diagram for creating an event (date in the past)}

This section covers a sequence diagram in a case where an event date is in the past. This is shown by Figure 34 below.

\subsubsection{Sequence diagram for uploading wrong image type}

In uploading images in the COP website, the allowed image types are png, jpeg, jpg, jpe and gif. This section covers a sequence diagram showing how the system handles this issue when a wrong image type has been selected. This has been shown as part of creation of a new page and it applies to different scenarios / functions that involve image uploads as shown by Figure 35. 


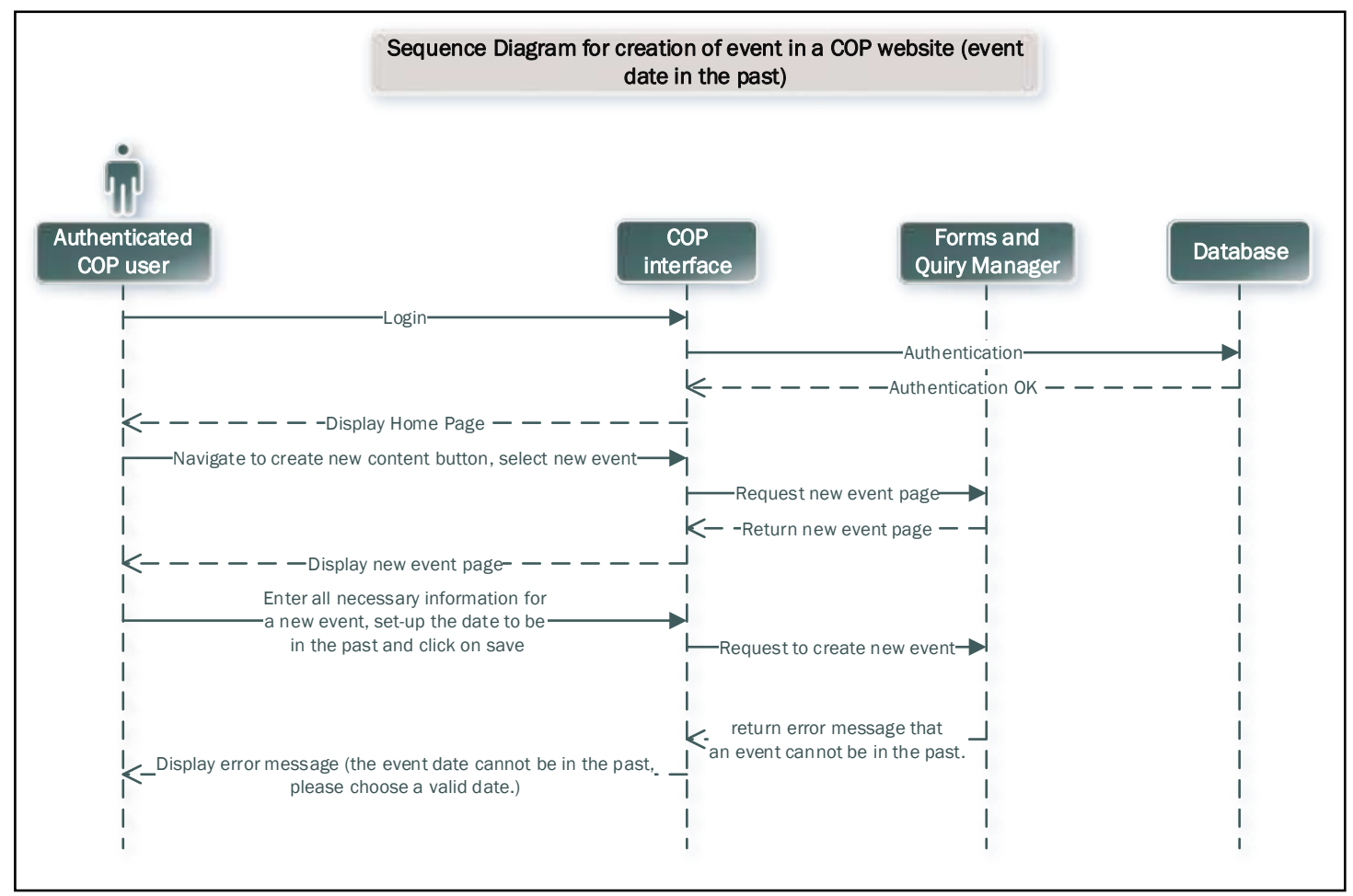

Figure 34 - sequence diagram for creation of an event (event date in the past)

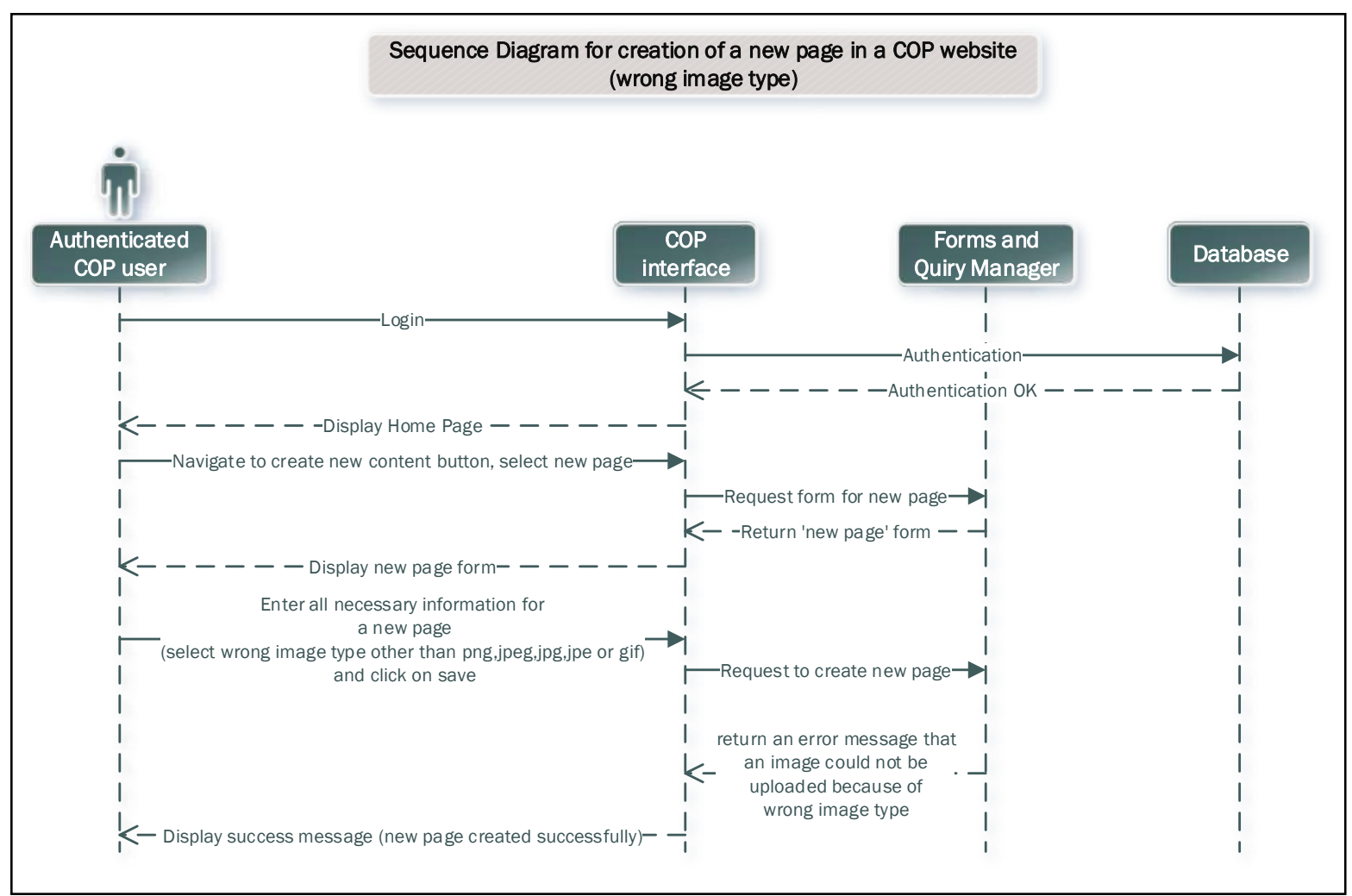

Figure 35 - Sequence diagram for creation of a new page (wrong image type) 
The next section looks into the development of the prototype including registration of the domain name for the website, choosing the host server and the installation process. 


\subsection{Development and choosing of technology to use}

This chapter looks into the development of the COP support website. It kicks off with registration of the domain name which will be used to access the COP support website. Furthermore, it covers choosing the hosting server and the reasons behind the choice. Lastly it explores the steps that were took to install the COP support website.

\subsubsection{Registration of a domain name}

To enable people who were in different places to test the COP website, a decision to hold it online as compared to hosting in a desktop was reached. The domain name for the COP website Mafcop.co.Is was registered in Lesotho.

\subsubsection{Choosing a hosting server}

There are different hosting environments that one can choose from. Linux-based hosting environment named cpanel was chosen for development of the COP website. Some of the key features of cPanel are as follows:

a. Set up email accounts, filters, auto responders and delivery tracking.

b. View the website statistics and the resource usage.

c. Upload, delete and edit files.

d. Change the file permissions.

e. Create, manage or delete databases.

f. Add hotlink protection and set up SSL certificates.

g. Install and manage scripts.

h. Create Cron Jobs with the intervals you want.

The features of the cPanel hosting environment are displayed in Figure 36. Sever information is displayed in Figure 37. Key features of the server include Apache, MySQL, and PHP which are key Drupal requirements. 


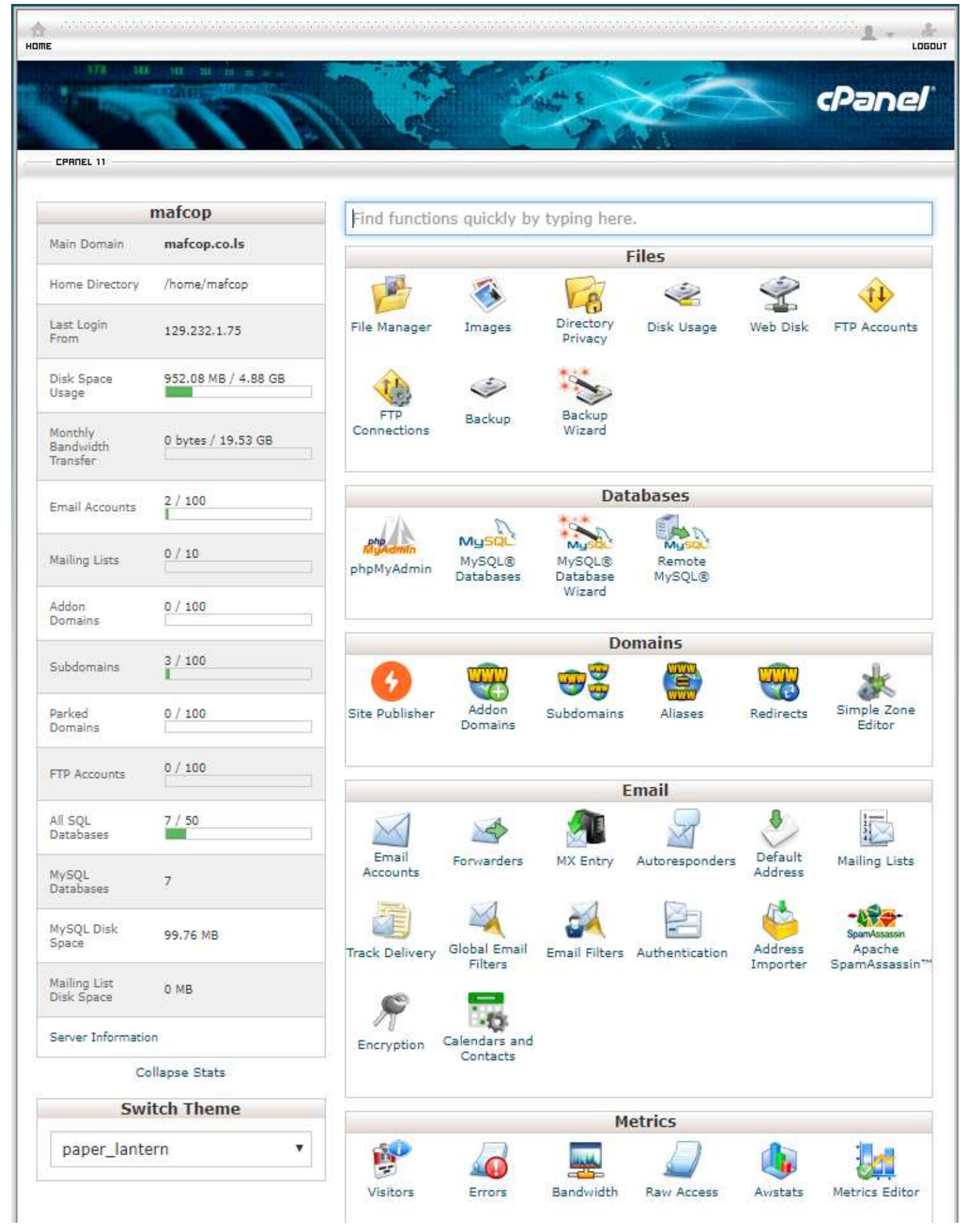

Figure 36 - cPanel server information 


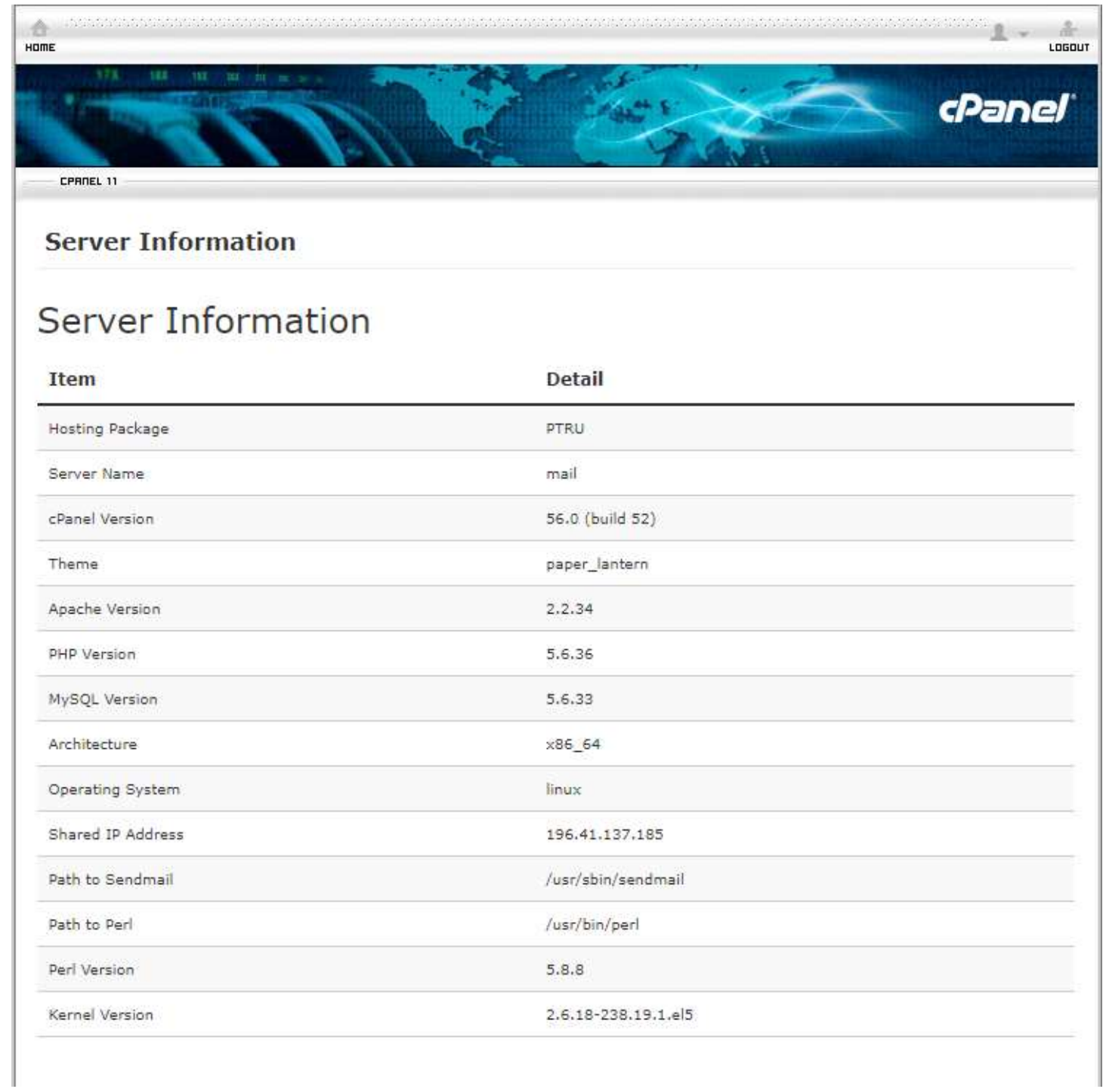

Figure 37 - cPanel server information

CPanel offers a comprehensive interface where users can administer every elementary aspect of their hosting accounts and websites at any time and place through a web browser. The build-in features of cPanel simplify the complicated server administration tasks to a large extent, so that even beginners can perform the basic hosting tasks with ease. [64] 


\subsubsection{Installation summary}

This section covers the installation and configuration of the COP website. Open social is a Drupal distribution that focuses mainly on communities. It is an out of the box solution for online communities. Open Social is a great match for external, knowledge and ideation communities. The software is used by NGOs, governments and hundreds of organizations big and small to connect with their members, volunteers, employees and customers. Customers regularly sponsor development of the Open Social distribution. Sponsors: The Pachamama Alliance, UNDP, foraus, Victim Support Netherlands [20]. Figure 38 depicts the overall installation process that was followed for installing open social

It is important that all the pre-requisites are double-checked before installation process begins. Such requirements are summarized below: [65]

- Database server: MySQL 5.5.3, MariaDB 5.520, Percona Server 5.5.8 or higher, PostgreSQL 9.1.2 or higher, SQLite 3.6.8 or higher.

- PHP: version 5.5 or higher.

- Webserver: Drupal 8 works on any web server with the version of PHP which meets above mentioned PHP requirements.

- Apache: this is the most commonly used web server for Drupal. Drupal will work on Apache 2.x hosted on UNIX/Linux, OS $\mathrm{X}$ or Windows operating systems.

- Nginx: this is a commonly used web server that focuses on high concurrency, performance and low memory usage. (supported versions: 0.7.x, 0.8.x, 1.0.x, 1.2.x,1.8.x, 1.9.x)

$\circ$ Hiawatha: this is a web server that has a strong focus on security and is fully compatible with Drupal.

- Microsoft IIS: this is a web server and a set of feature extension modules for use with Microsoft Windows. (supported versions: IIS 5, IIS 6 , IIS 7 or IIS 8 ) 


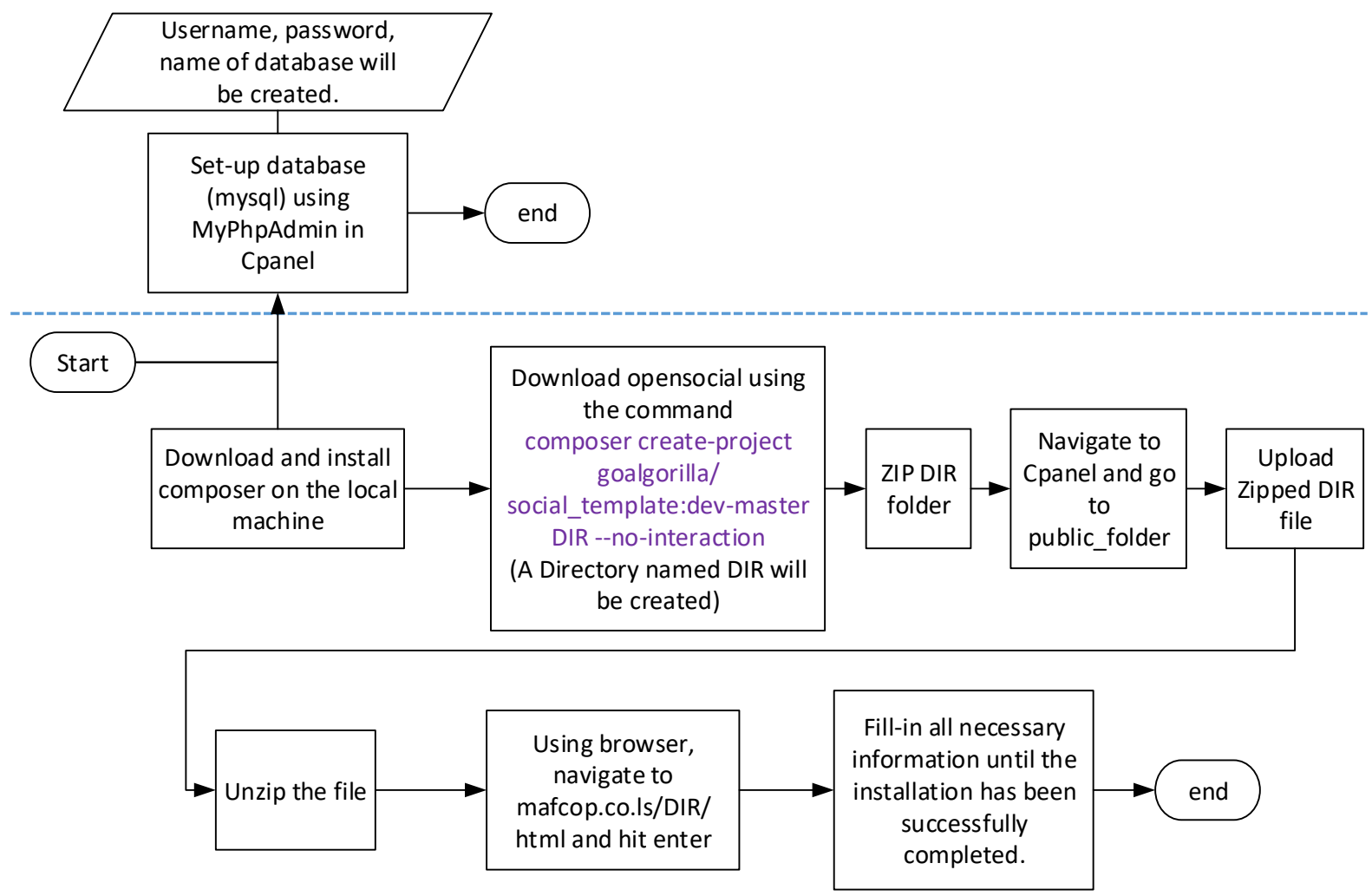

Figure 38 - Open Social installation process (note that both top and bottom flow charts can run simultaneously)

The next Chapter explores experiments and results as per different test cases that were performed on the Prototype. 


\section{Experiments and Results}

This chapter focuses on the experiment performed to test the system and the subsequent results that were gathered after the development of the prototype system (COP website).

Once the website development was completed to support the different use cases, the testing process began. Both functional testing and non-functional tests were performed as per test cases covered under section 4.2.4. Table 1.8 below shows the summary of the test results.

Table 1.8: Summary of test results

\begin{tabular}{|c|c|c|c|c|}
\hline $\begin{array}{l}\text { Test } \\
\text { Number }\end{array}$ & Description & Functions Checked & $\begin{array}{l}\text { Requirements } \\
\text { Tested }\end{array}$ & Test Result \\
\hline $\begin{array}{l}\text { Test Case } \\
1.1\end{array}$ & Login Functionality & $\begin{array}{l}\text { Test the Login } \\
\text { functionality of the COP } \\
\text { website using correct } \\
\text { login credentials. }\end{array}$ & Security. & Passed \\
\hline $\begin{array}{l}\text { Test Case } \\
1.2\end{array}$ & Login Functionality & $\begin{array}{l}\text { Test the Login } \\
\text { functionality of the COP } \\
\text { website using incorrect } \\
\text { login credentials. }\end{array}$ & Security & Passed \\
\hline Test Case 2 & $\begin{array}{l}\text { Creation of an } \\
\text { event }\end{array}$ & $\begin{array}{l}\text { Creation of an event } \\
\text { functionality in the COP } \\
\text { website. }\end{array}$ & $\begin{array}{l}\text { Asynchronous } \\
\text { communication }\end{array}$ & Passed \\
\hline $\begin{array}{l}\text { Test Case } \\
2.1\end{array}$ & $\begin{array}{l}\text { Creation of an } \\
\text { event (date in the } \\
\text { past) }\end{array}$ & $\begin{array}{l}\text { Creation of an event } \\
\text { functionality in the COP } \\
\text { website. (date in the } \\
\text { past) }\end{array}$ & $\begin{array}{l}\text { Fault condition: } \\
\text { setting an event in } \\
\text { the past }\end{array}$ & Passed \\
\hline Test Case 3 & $\begin{array}{l}\text { Creation of a } \\
\text { group }\end{array}$ & $\begin{array}{l}\text { Test creation of a group } \\
\text { in the COP website }\end{array}$ & $\begin{array}{l}\text { Groups: } \\
\text { Configuration and } \\
\text { creation of } \\
\text { collaboration groups }\end{array}$ & Passed \\
\hline
\end{tabular}




\begin{tabular}{|c|c|c|c|c|}
\hline Test Case 4 & $\begin{array}{l}\text { Creation of a basic } \\
\text { page }\end{array}$ & $\begin{array}{l}\text { Test creation of a basic } \\
\text { page }\end{array}$ & $\begin{array}{l}\text { Asynchronous } \\
\text { communication: }\end{array}$ & Passed \\
\hline $\begin{array}{l}\text { Test Case } \\
4.1\end{array}$ & $\begin{array}{l}\text { Creation of a basic } \\
\text { page (upload } \\
\text { wrong image type) }\end{array}$ & $\begin{array}{l}\text { Test creation of a basic } \\
\text { page (upload wrong } \\
\text { image type) }\end{array}$ & $\begin{array}{l}\text { Fault condition: } \\
\text { uploading wrong } \\
\text { image type. }\end{array}$ & Passed \\
\hline Test Case 5 & $\begin{array}{l}\text { Creation of a } \\
\text { profile }\end{array}$ & $\begin{array}{l}\text { Test creation of a } \\
\text { profile }\end{array}$ & $\begin{array}{l}\text { Profile: A COP } \\
\text { member shall be able } \\
\text { to create and } \\
\text { maintain his or her } \\
\text { own profile. }\end{array}$ & Passed \\
\hline Test Case 6 & $\begin{array}{l}\text { Creation of a new } \\
\text { topic }\end{array}$ & $\begin{array}{l}\text { Test creation of a new } \\
\text { topic }\end{array}$ & $\begin{array}{l}\text { Asynchronous } \\
\text { communication: }\end{array}$ & Passed \\
\hline Test Case 7 & CHAT functionality & $\begin{array}{l}\text { Test real time } \\
\text { communication using } \\
\text { CHAT }\end{array}$ & $\begin{array}{l}\text { Synchronous } \\
\text { communication }\end{array}$ & $\begin{array}{l}\text { Not } \\
\text { performed }\end{array}$ \\
\hline Test Case 8 & RSS Feeds & Test RSS Feeds & RSS Feeds & $\begin{array}{l}\text { Not } \\
\text { Performed }\end{array}$ \\
\hline Test Case 9 & $\begin{array}{l}\text { Pages Loading } \\
\text { time }\end{array}$ & $\begin{array}{l}\text { How long pages take to } \\
\text { load }\end{array}$ & Pages loading time & Passed \\
\hline
\end{tabular}

As indicated in the subsections below, 12 test cases are presented. Appendix A has further images depicting the test case results. In the following sections test case results are discussed.

\subsection{Test case 1.1: Login functionality}

This test case focuses on assessing the login support provided by the system. Table 7 summarises the test report for login functionality. 
The sequence of activities done for this test are documented in "Step Details" section of the test report (see Table 1.9).

The test was a success and Figure 39 is the landing page after successful login.

Table 1.9: Report for Test Case 1.1 - Login Functionality

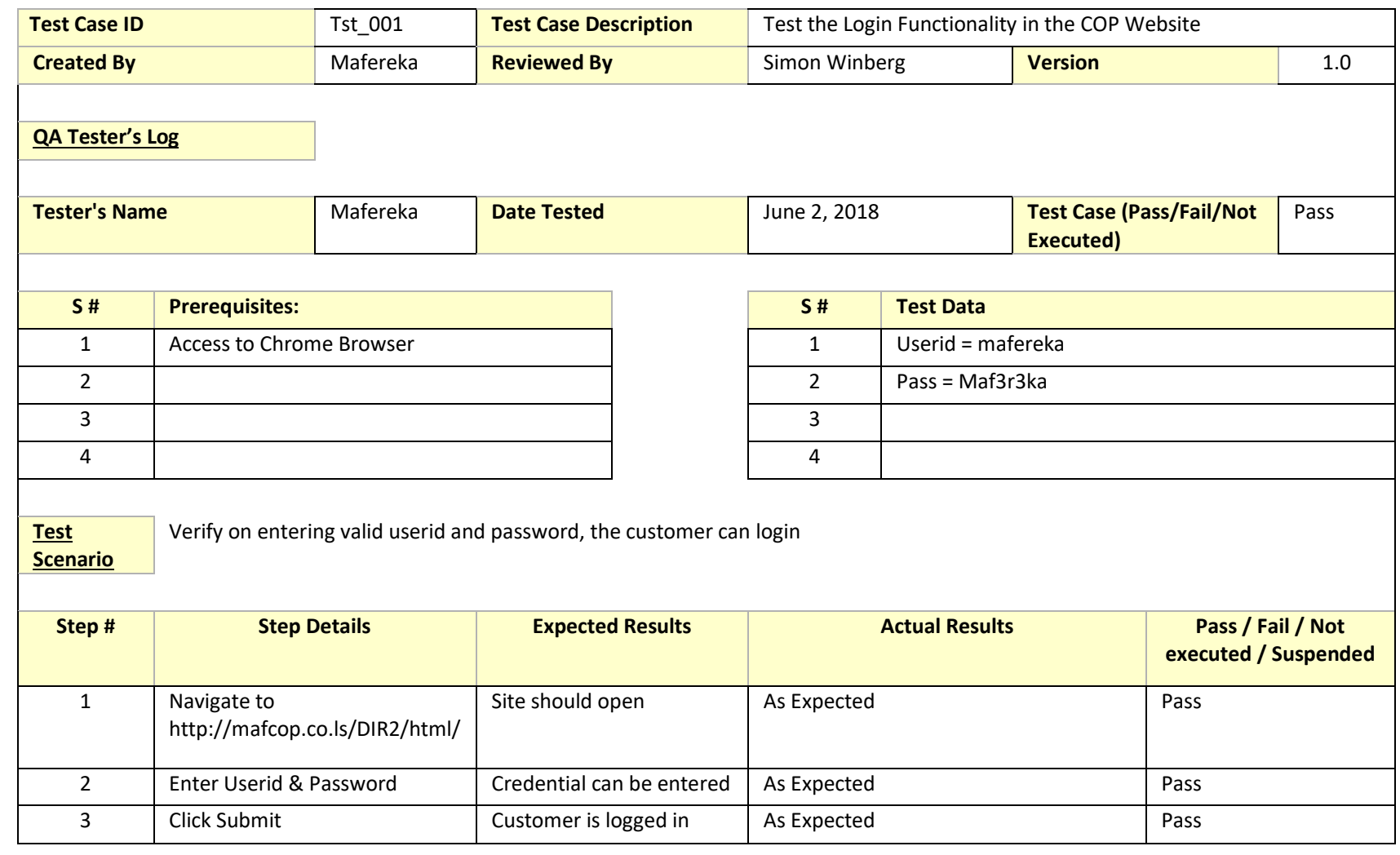




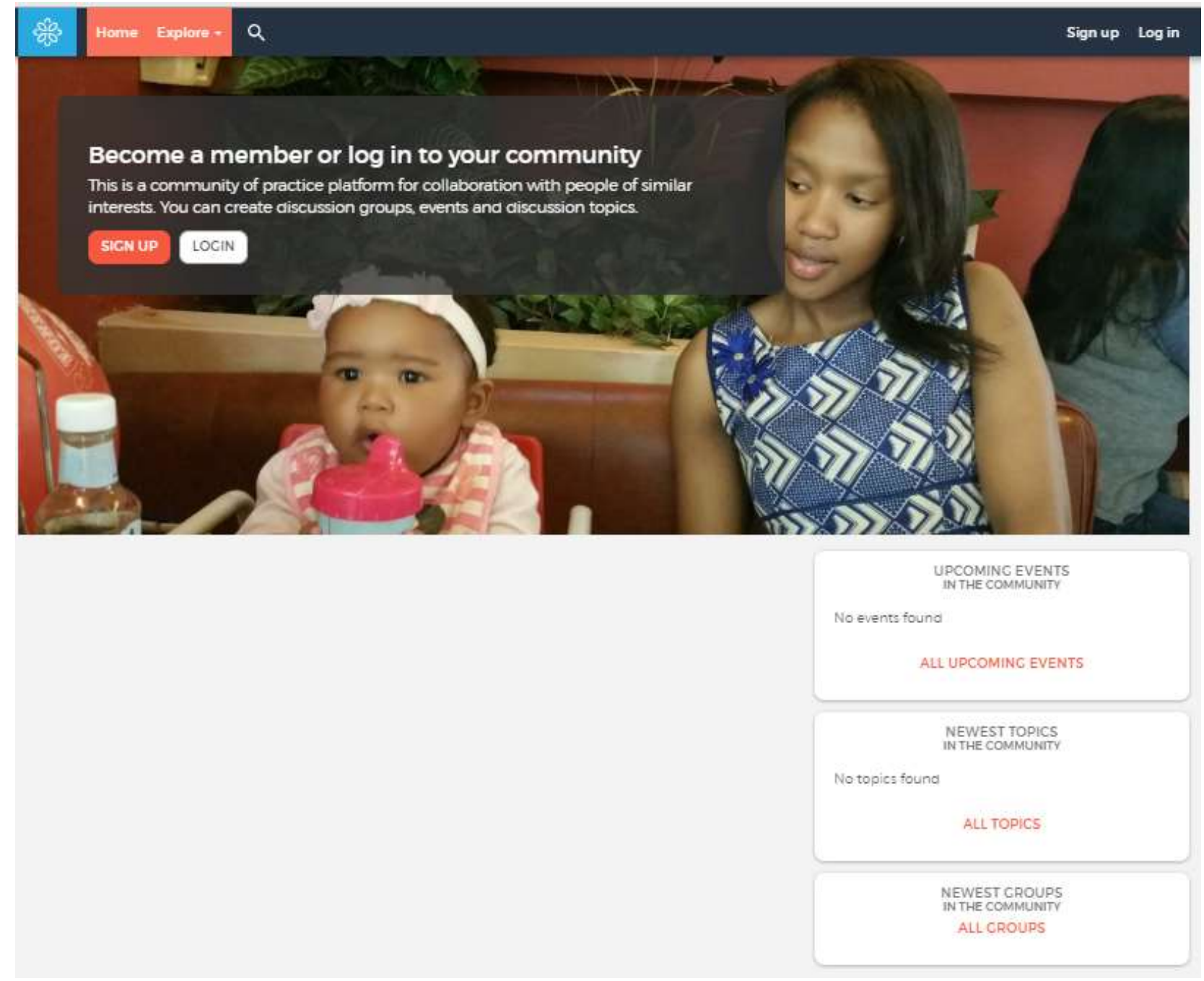

Figure 39 - Landing Page (step 1)

Home Explore - Q

Log in

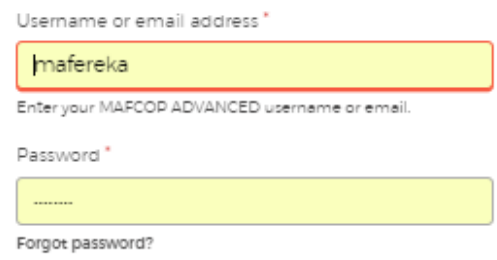

Figure 40 - login screen for entering security credentials 


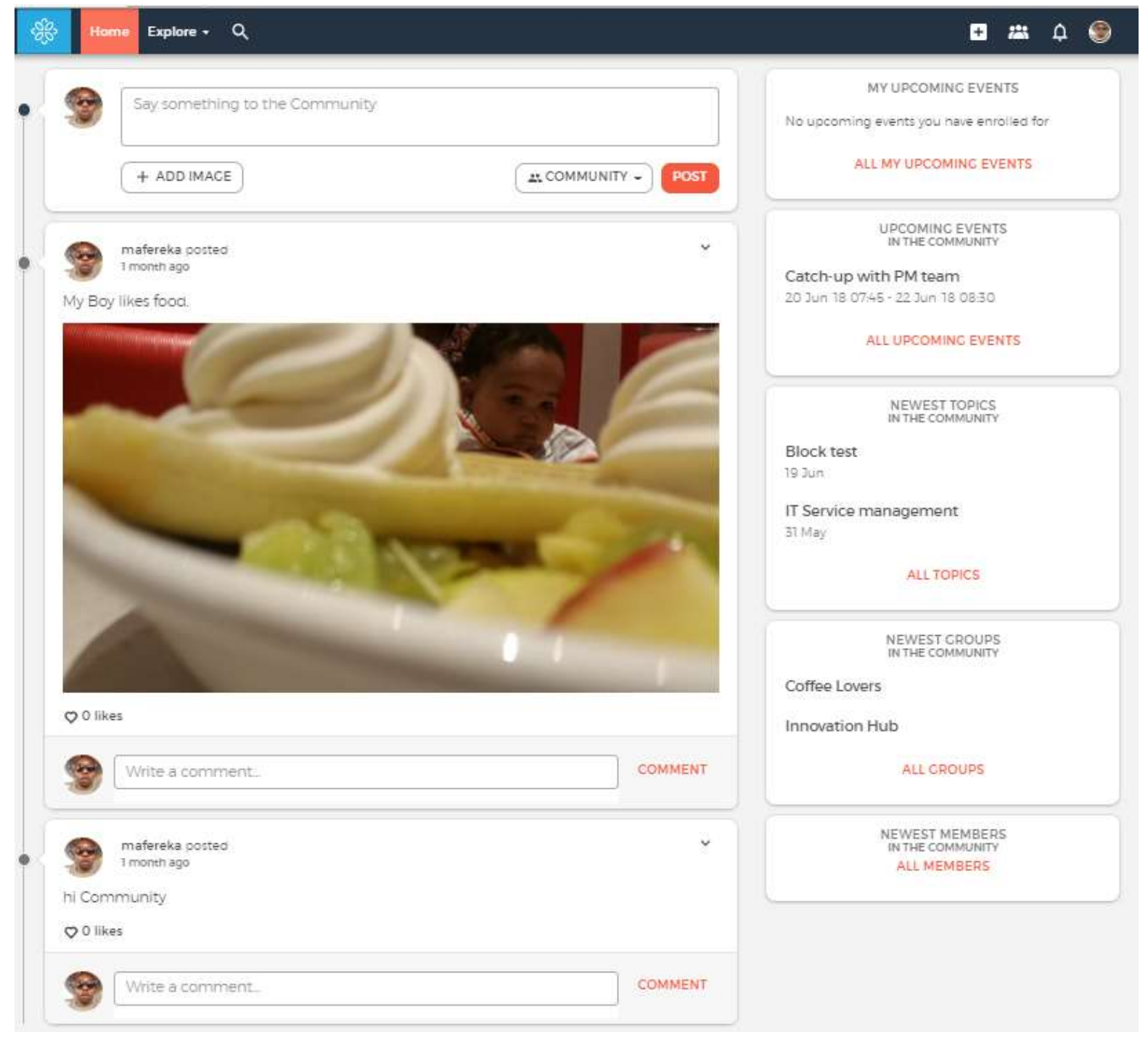

Figure 41 - Landing page after entering correct password

\subsection{Test Case 1.2: Faulty Login}

Another test case on login functionality where incorrect login details were provided is summarized by Table 1.10 below. The test passed and Figure 42 shows the error message as a result of entering incorrect details. 
Table 1.10: Test Case 1.2 results (login functionality)

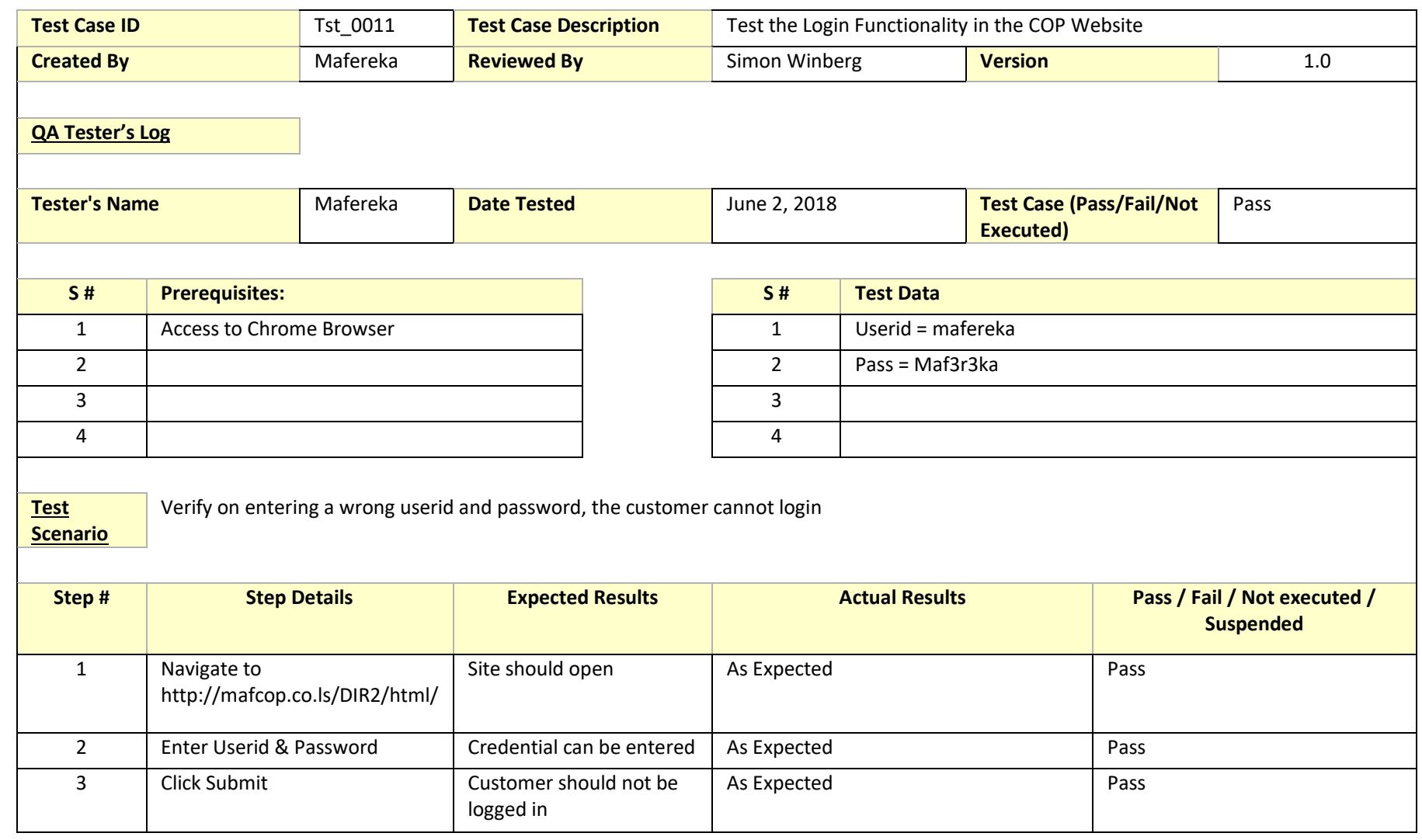

Log in

There was an ertor ( This could happen for cone of for the following reasons

- Uniecognized usermame/errall and password combination

There has been more than one faled lagin atrempt for this account it is temporanly blocked

- Too mary talied iogin attempts from your ip addiess. This ip address is temporanly blocked

To solve the issue try other credentials, try again later or request a new password

Usemarne or emall acidiess"

maferekal

Enter your MAFCOP ADVANACED UDEmarne or Email

Passmord:

Forgot passwordy

Figure 42 - Error Message after entering incorrect password (Step 3) 


\subsection{Test Case 2: Creation of an event}

Results of Test Case 2 are depicted in Table 1.11. Creation of an event was a success and Figure 43 shows an event that was successfully created.

Table 1.11: Test Case 2 results (Creation of an event)

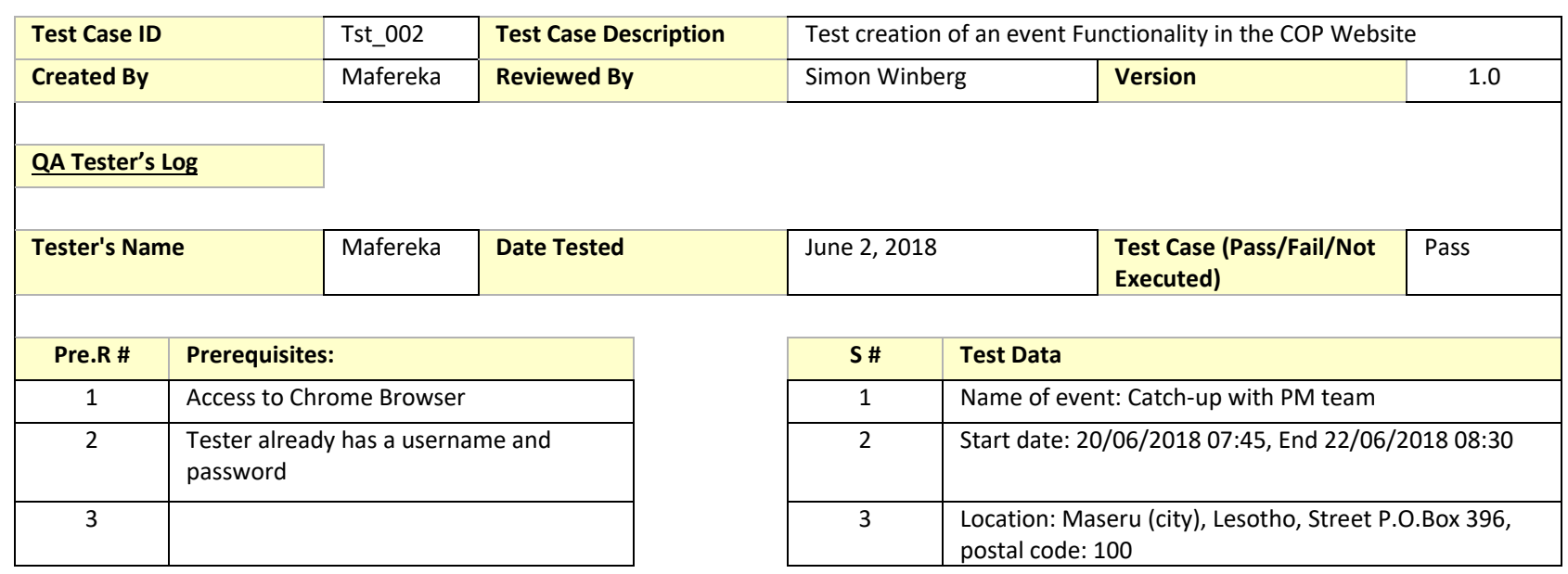

\begin{tabular}{|c|c|c|c|c|}
\hline Test & create an event using test $c$ & & & \\
\hline Step \# & Step Details & Expected Results & Actual Results & $\begin{array}{c}\text { Pass / Fail / Not executed } \\
\text { / Suspended }\end{array}$ \\
\hline 1 & $\begin{array}{l}\text { Click icon to add new } \\
\text { content }\end{array}$ & $\begin{array}{l}\text { dropdown for selecting } \\
\text { content should appear }\end{array}$ & As Expected & Pass \\
\hline 2 & Select new event & $\begin{array}{l}\text { page for creating new } \\
\text { event should open }\end{array}$ & As Expected & Pass \\
\hline 3 & $\begin{array}{l}\text { enter the title of the } \\
\text { event }\end{array}$ & title should be displayed & As Expected & Pass \\
\hline 4 & $\begin{array}{l}\text { browse for an event } \\
\text { image }\end{array}$ & $\begin{array}{l}\text { selected image should be } \\
\text { displayed and ready for } \\
\text { cropping }\end{array}$ & As Expected & Pass \\
\hline 5 & crop it to make it fit & image should resize & As Expected & Pass \\
\hline 6 & enter start and end date & $\begin{array}{l}\text { the dates and time should } \\
\text { be displayed }\end{array}$ & As Expected & Pass \\
\hline 7 & enter Location details & $\begin{array}{l}\text { Location settings should } \\
\text { be displayed. }\end{array}$ & As Expected & Pass \\
\hline 8 & Enter description of event & $\begin{array}{l}\text { Description of the event } \\
\text { should be displayed. }\end{array}$ & As Expected & Pass \\
\hline 9 & attach files for an event & $\begin{array}{l}\text { Icon for attached files and } \\
\text { description of such files } \\
\text { should be displayed. }\end{array}$ & As Expected & Pass \\
\hline 10 & select save & $\begin{array}{l}\text { Success message should } \\
\text { be displayed and the user } \\
\text { should be redirected to } \\
\text { newly created event } \\
\text { page. }\end{array}$ & As Expected & Pass \\
\hline
\end{tabular}




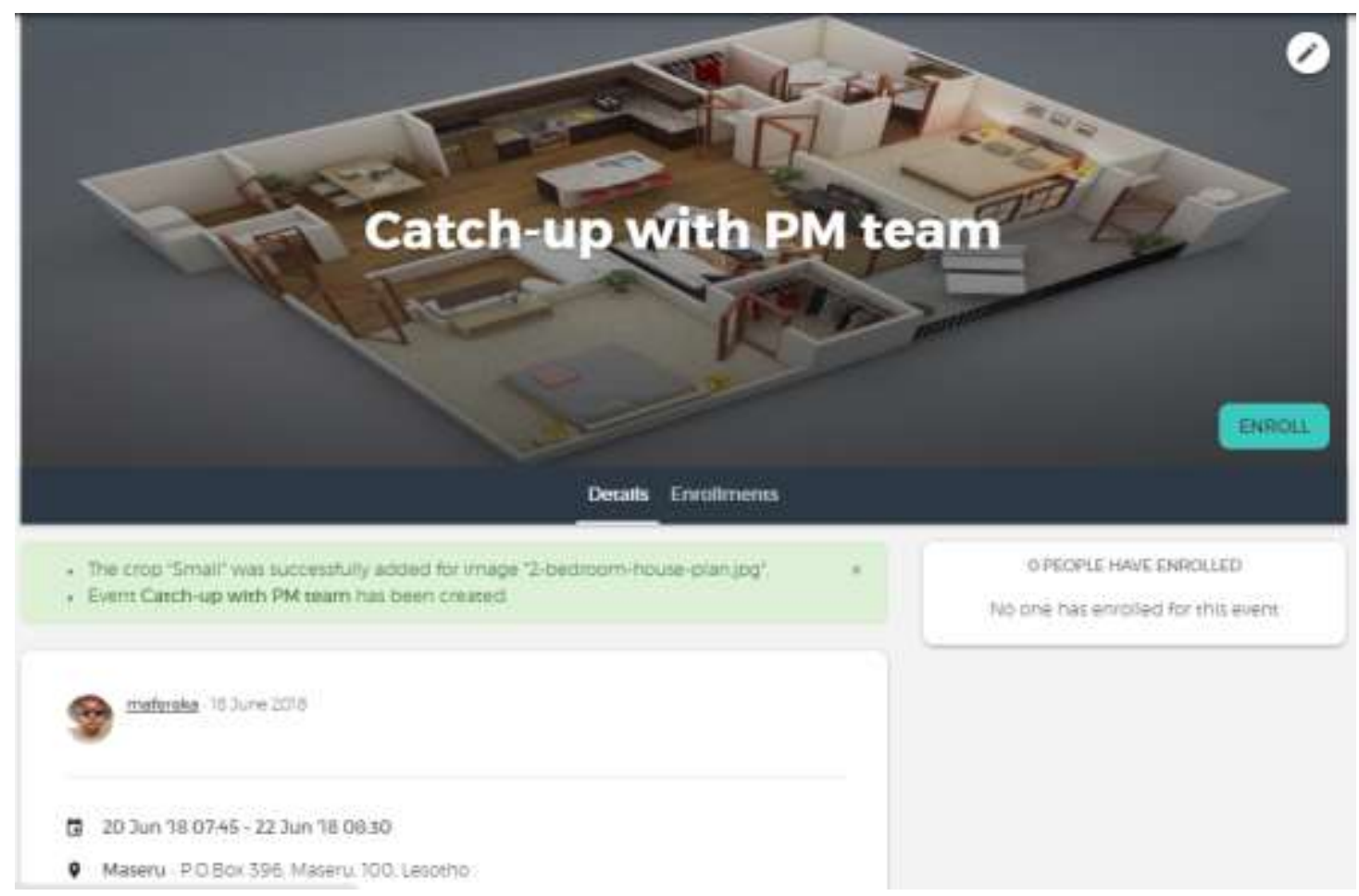

Figure 43 - Creation of an event (step 8)

\subsection{Test Case 2.1: Creation of an event (date in the past)}

Negative testing in a scenario whereby past date is entered for creation of an event was performed. Table 1.12 shows the result of this test case.

Table 1.12: Creation of an event (date in the past)

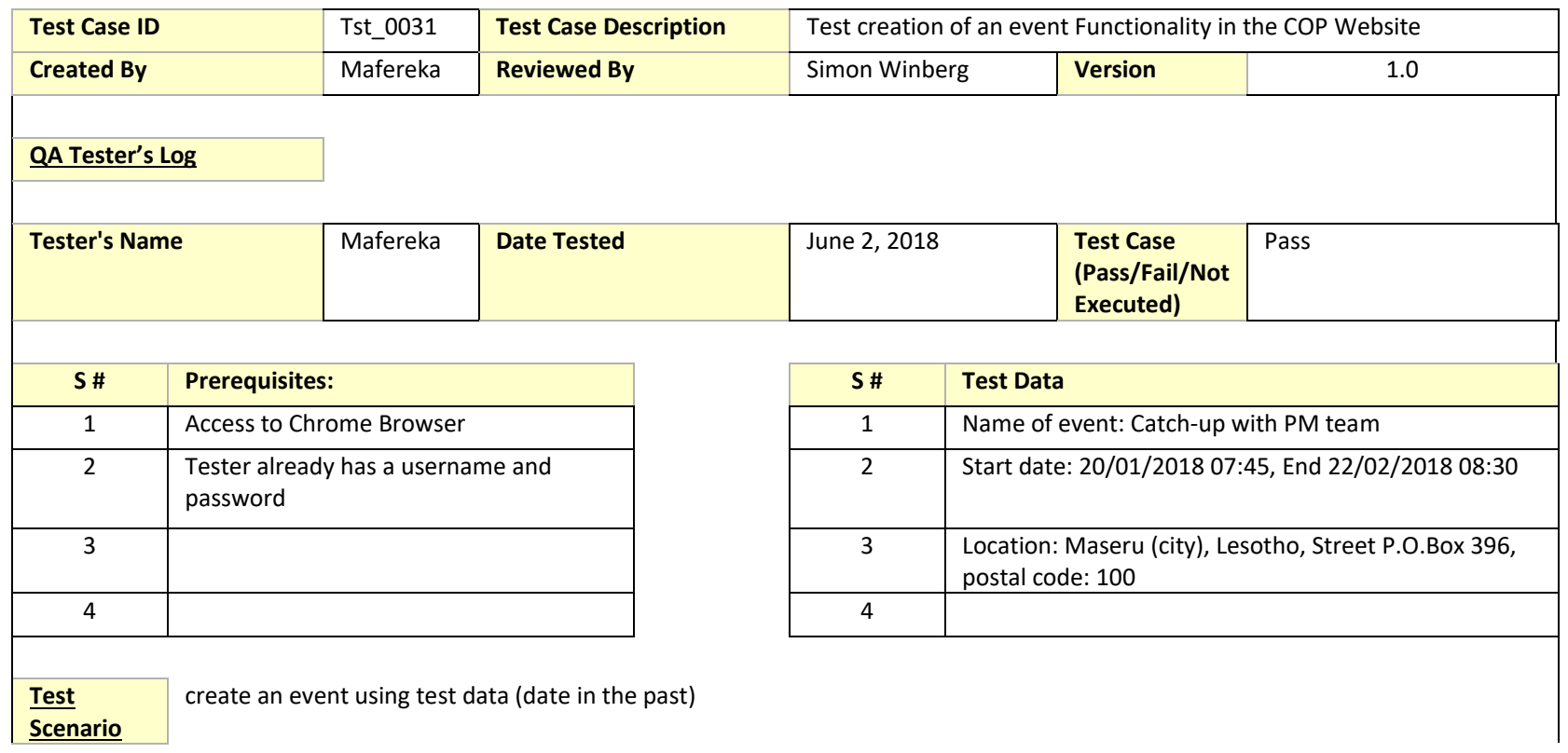




\begin{tabular}{|c|c|c|c|c|}
\hline Step \# & Step Details & Expected Results & Actual Results & Pass / Fail / Not executed / Suspended \\
\hline 1 & $\begin{array}{l}\text { Click icon to add new } \\
\text { content }\end{array}$ & $\begin{array}{l}\text { dropdown for selecting } \\
\text { content should appear }\end{array}$ & As Expected & Pass \\
\hline 2 & Select new event & $\begin{array}{l}\text { page for creating new } \\
\text { event should open }\end{array}$ & As Expected & Pass \\
\hline 3 & $\begin{array}{l}\text { enter the title of the } \\
\text { event }\end{array}$ & title should be displayed & As Expected & Pass \\
\hline 4 & $\begin{array}{l}\text { browse for an event } \\
\text { image }\end{array}$ & $\begin{array}{l}\text { selected image should be } \\
\text { displayed and ready for } \\
\text { cropping }\end{array}$ & As Expected & Pass \\
\hline 5 & crop it to make it fit & image should resize & As Expected & Pass \\
\hline 6 & enter start and end date & $\begin{array}{l}\text { Error message should be } \\
\text { displayed because of the } \\
\text { date which is in the past. }\end{array}$ & As Expected & Pass \\
\hline
\end{tabular}

An error message should be displayed when the COP user tries to use the past dates for creation of an event. The error message was displayed when executing this test case as shown by Figure 44 .

\section{$88_{3}$ Home Explore - Q}

Add content > Create Event

\section{Create Event}

Body field is required

The Authored on date is invalid. Please enter a date in the format 2018-11-11

13:59:53

TITLE \& IMAGE

Title*

drupal Gurus collaboration

Image

(2) Upload requirements . Crop your image to select which part of your image to show on display.

Figure 44 - Error Message (test case 2.1) 


\subsection{Test Case 3: Creation of a new group}

Functionality for creation of a group was a success and table 1.13 summarises such results. Figure 45 show cases the group that was created successfully.

Table 1.13: Creation of a new group

\begin{tabular}{|c|c|c|c|c|c|c|}
\hline \multirow{2}{*}{\multicolumn{2}{|c|}{$\begin{array}{l}\text { Test Case ID } \\
\text { Created By }\end{array}$}} & \multirow{2}{*}{$\begin{array}{l}\text { Test Case Description } \\
\text { Reviewed By }\end{array}$} & \multicolumn{4}{|c|}{ Test creation of a new group } \\
\hline & & & \multicolumn{2}{|c|}{ Simon Winberg } & Version & 1.0 \\
\hline \multicolumn{7}{|l|}{ QA Tester's Log } \\
\hline \multicolumn{2}{|l|}{ Tester's Name } & Date Tested & \multicolumn{2}{|l|}{ June 2, 2018} & $\begin{array}{l}\text { Test Case } \\
\text { (Pass/Fail/Not } \\
\text { Executed) }\end{array}$ & Pass \\
\hline S \# & \multicolumn{2}{|l|}{ Prerequisites: } & S \# & \multicolumn{3}{|c|}{ Test Data } \\
\hline 1 & \multicolumn{2}{|l|}{ Access to Chrome Browser } & 1 & \multicolumn{3}{|c|}{ type of group: open } \\
\hline 2 & \multirow{3}{*}{\multicolumn{2}{|c|}{$\begin{array}{l}\text { Tester already has a username and } \\
\text { password }\end{array}$}} & 2 & \multicolumn{3}{|c|}{$\begin{array}{l}\text { Name of group: coffee Lovers, description: "This } \\
\text { is a group for bringing together different coffee } \\
\text { lovers" }\end{array}$} \\
\hline 3 & & & 3 & \multicolumn{3}{|c|}{ a photo of coffee container } \\
\hline 4 & & & 4 & \multicolumn{3}{|c|}{ Location: Cape town, South Africa } \\
\hline 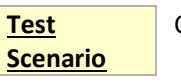 & \multicolumn{6}{|c|}{ Create a group using the test data } \\
\hline Step \# & Step Details & Expected Results & Actual & Results & $\begin{array}{r}\text { Pass / Fail } \\
\text { Si }\end{array}$ & $\begin{array}{l}\text { Not executed / } \\
\text { pended }\end{array}$ \\
\hline 1 & $\begin{array}{l}\text { Click icon to add new } \\
\text { content }\end{array}$ & $\begin{array}{l}\text { dropdown for selecting } \\
\text { content should appear }\end{array}$ & As Expected & & Pass & \\
\hline 2 & Select new group & $\begin{array}{l}\text { page for creating new } \\
\text { group should open }\end{array}$ & As Expected & & Pass & \\
\hline 3 & $\begin{array}{l}\text { Enter the title of the } \\
\text { group }\end{array}$ & $\begin{array}{l}\text { title of a new group } \\
\text { should be displayed }\end{array}$ & As Expected & & Pass & \\
\hline 4 & Enter description of group & $\begin{array}{l}\text { Group description should } \\
\text { be displayed. }\end{array}$ & As Expected & & Pass & \\
\hline 5 & Browse for a group image & $\begin{array}{l}\text { selected image should be } \\
\text { displayed and ready for } \\
\text { cropping }\end{array}$ & As Expected & & Pass & \\
\hline 6 & Crop it to make it fit & Image should resize & As Expected & & Pass & \\
\hline 7 & Enter Location details & $\begin{array}{l}\text { Location settings should } \\
\text { be displayed. }\end{array}$ & As Expected & & Pass & \\
\hline 8 & Select save & $\begin{array}{l}\text { Success message should } \\
\text { be displayed and the user } \\
\text { should be redirected to } \\
\text { newly created group } \\
\text { page. }\end{array}$ & As Expected & & Pass & \\
\hline
\end{tabular}




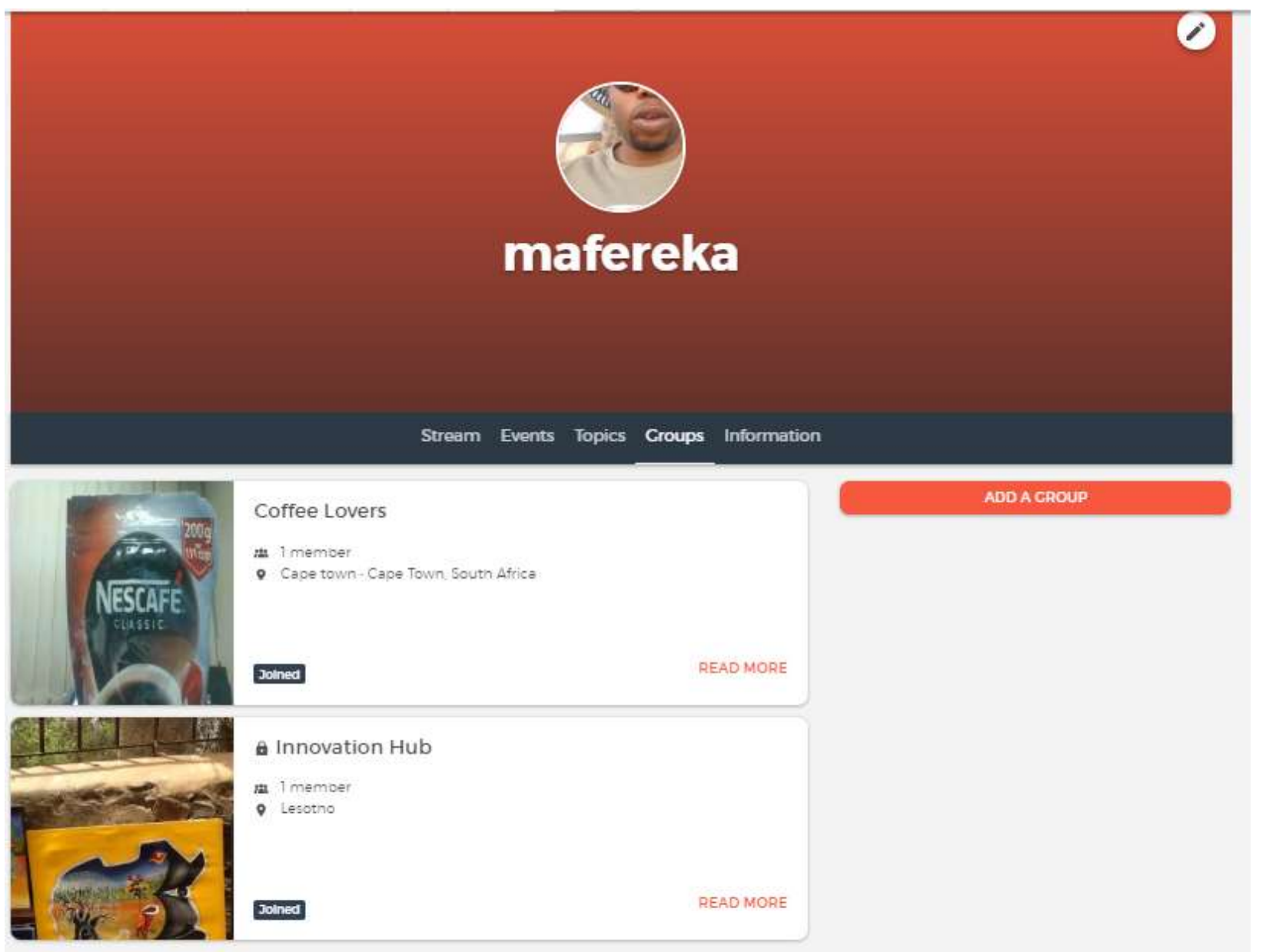

Figure 45 - creation of a new group (step 8)

\subsection{Test Case 4: Creation of a basic page}

This test case focuses on creating a basic information page in the system, which can only be accessed by authenticated users.

Table 1.14 summarises results for creation of a basic page test case. Figure 46 is the diagram portraying the page that was create successfully. 
Table 1.14: Table 2 - Creation of a basic page

\begin{tabular}{|c|c|c|c|c|c|c|c|}
\hline \multirow{2}{*}{\multicolumn{2}{|c|}{$\begin{array}{l}\text { Test Case ID } \\
\text { Created By }\end{array}$}} & \multirow{2}{*}{$\begin{array}{l}\text { Test Case Description } \\
\text { Reviewed By }\end{array}$} & \multicolumn{5}{|c|}{ Creation of a basic page } \\
\hline & & & \multicolumn{2}{|c|}{ Simon Winberg } & \multicolumn{2}{|c|}{ Version } & 1.0 \\
\hline \multicolumn{8}{|c|}{$\underline{\text { QA Tester's Log }}$} \\
\hline \multicolumn{2}{|c|}{ Tester's Name } & Date Tested & \multicolumn{2}{|c|}{ June 2, 2018} & \multicolumn{2}{|c|}{$\begin{array}{l}\text { Test Case (Pass/Fail/Not } \\
\text { Executed) }\end{array}$} & Pass \\
\hline S \# & \multicolumn{2}{|l|}{ Prerequisites: } & S \# & \multicolumn{4}{|l|}{ Test Data } \\
\hline 1 & \multicolumn{2}{|l|}{ Access to Chrome Browser } & 1 & \multicolumn{4}{|c|}{ Title of a page: "knowledge" } \\
\hline 2 & \multicolumn{2}{|c|}{ Tester should have user name and password } & 2 & \multicolumn{4}{|c|}{ visibility: community -visible only to logged in members } \\
\hline \multirow[t]{3}{*}{3} & & & 3 & \multicolumn{4}{|c|}{ Image: image selected for basic page. } \\
\hline & & & 4 & \multicolumn{4}{|c|}{$\begin{array}{l}\text { Description: "This is a page for sharing knowledge. } \\
\text { Knowledge is the new currency of a thriving economy" }\end{array}$} \\
\hline & & & 5 & \multicolumn{4}{|c|}{$\begin{array}{l}\text { files: a) motivation.txt, file description: " Motivation" } \\
\text { b) Get-Your-financial-house-on-order.pdf: description: } \\
\text { Financial Fitness }\end{array}$} \\
\hline$\underline{\underline{\text { Test }}}$ & \multicolumn{7}{|c|}{ Verify that a basic page is created successfully with the test data supplied } \\
\hline Step \# & Step Details & Expected Results & \multicolumn{3}{|c|}{ Actual Results } & \multicolumn{2}{|c|}{$\begin{array}{c}\text { Pass / Fail / Not executed / } \\
\text { Suspended }\end{array}$} \\
\hline 1 & Click icon to add new content & $\begin{array}{l}\text { dropdown for selecting content } \\
\text { should appear }\end{array}$ & \multicolumn{3}{|c|}{ As Expected } & \multicolumn{2}{|l|}{ Pass } \\
\hline 2 & Select new page & $\begin{array}{l}\text { page for creating new page } \\
\text { should open }\end{array}$ & \multicolumn{3}{|c|}{ As Expected } & \multicolumn{2}{|l|}{ Pass } \\
\hline 3 & Enter the title of the page & $\begin{array}{l}\text { title of a new page should be } \\
\text { displayed }\end{array}$ & \multicolumn{3}{|c|}{ As Expected } & \multicolumn{2}{|l|}{ Pass } \\
\hline 4 & Enter description of page & $\begin{array}{l}\text { Page description should be } \\
\text { displayed. }\end{array}$ & \multicolumn{3}{|c|}{ As Expected } & Pass & \\
\hline 5 & Browse for a page image & $\begin{array}{l}\text { selected image should be } \\
\text { displayed and ready for cropping }\end{array}$ & As $\mathrm{E}$ & pected & & Pass & \\
\hline 6 & crop it to make it fit & Image should resize & As E & pected & & Pass & \\
\hline 7 & $\begin{array}{l}\text { Under a new file: select choose } \\
\text { file and navigate to } \\
\text { motivation.txt }\end{array}$ & $\begin{array}{l}\text { The file should be uploaded and } \\
\text { its icon should be displayed }\end{array}$ & As $\mathrm{E}$ & pected & & Pass & \\
\hline 8 & $\begin{array}{l}\text { Under file information, } \\
\text { Description, type "Motivation" }\end{array}$ & $\begin{array}{l}\text { Attachment description: } \\
\text { "Motivation" should be } \\
\text { displayed. }\end{array}$ & As E & pected & & Pass & \\
\hline 9 & $\begin{array}{l}\text { Under a new file: select choose } \\
\text { file and navigate to Get-Your- } \\
\text { financial-house-on-order.pdf }\end{array}$ & $\begin{array}{l}\text { The file should be uploaded and } \\
\text { its icon should be displayed }\end{array}$ & As $\mathrm{E}$ & pected & & Pass & \\
\hline 10 & $\begin{array}{l}\text { Under file information, } \\
\text { Description, type "Financial } \\
\text { Fitness" }\end{array}$ & $\begin{array}{l}\text { Attachment description: } \\
\text { "Financial Fitness" should be } \\
\text { displayed. }\end{array}$ & As $\mathrm{E}$ & pected & & Pass & \\
\hline 11 & Select Save & $\begin{array}{l}\text { success message should be } \\
\text { displayed and the user should be } \\
\text { redirected to newly created } \\
\text { page }\end{array}$ & As $\mathrm{E}$ & pected & & Pass & \\
\hline
\end{tabular}




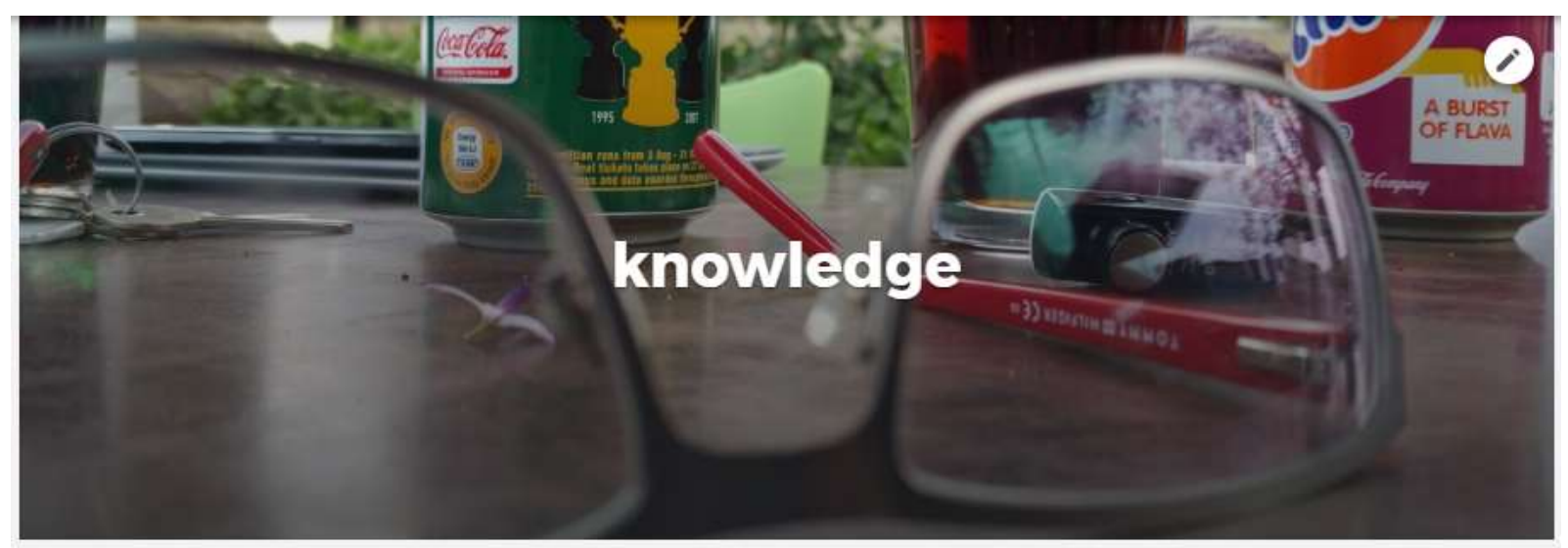

2. community

FOLLOW CONTENT

This is a page for sharing knowledge. knowledge is the new currency of a thriving economy.

Files

Motivation

Financial fitness

Figure 46 - Creation of a basic page (step 11)

\subsection{Test Case 4.1: Creation of a basic page (upload wrong image type)}

This test case focuses on testing how the system will react when a wrong image type is selected during the creation of a basic page. The expected end result is for the system to issue an error message alerting the user that a wrong image was selected. This test case was a success as shown by Table 1.15 and Figure 47.

Table 1.15: Test case 4.1 uploading wrong image type

\begin{tabular}{|c|c|c|c|c|c|c|c|}
\hline \multirow{2}{*}{\multicolumn{2}{|c|}{$\begin{array}{l}\text { Test Case ID } \\
\text { Created By }\end{array}$}} & \multirow{2}{*}{$\begin{array}{l}\text { Tst_0051 } \\
\text { Mafereka }\end{array}$} & \multirow{2}{*}{$\begin{array}{l}\text { Test Case Description } \\
\text { Reviewed By }\end{array}$} & \multicolumn{4}{|c|}{ Creation of a basic page } \\
\hline & & & & \multicolumn{2}{|c|}{ Simon Winberg } & Version & 1.0 \\
\hline \multicolumn{8}{|c|}{ QA Tester's Log } \\
\hline \multicolumn{2}{|c|}{ Tester's Name } & Mafereka & Date Tested & \multicolumn{2}{|c|}{ June 2, 2018} & $\begin{array}{l}\text { Test Case } \\
\text { (Pass/Fail/Not } \\
\text { Executed) }\end{array}$ & Pass \\
\hline S \# & \multicolumn{2}{|c|}{ Prerequisites: } & & S \# & \multicolumn{2}{|c|}{ Test Data } & \\
\hline 1 & \multicolumn{2}{|c|}{ Access to Chrome Browser } & & 1 & \multicolumn{2}{|c|}{ Title of a page: "knowledge" } & \\
\hline
\end{tabular}




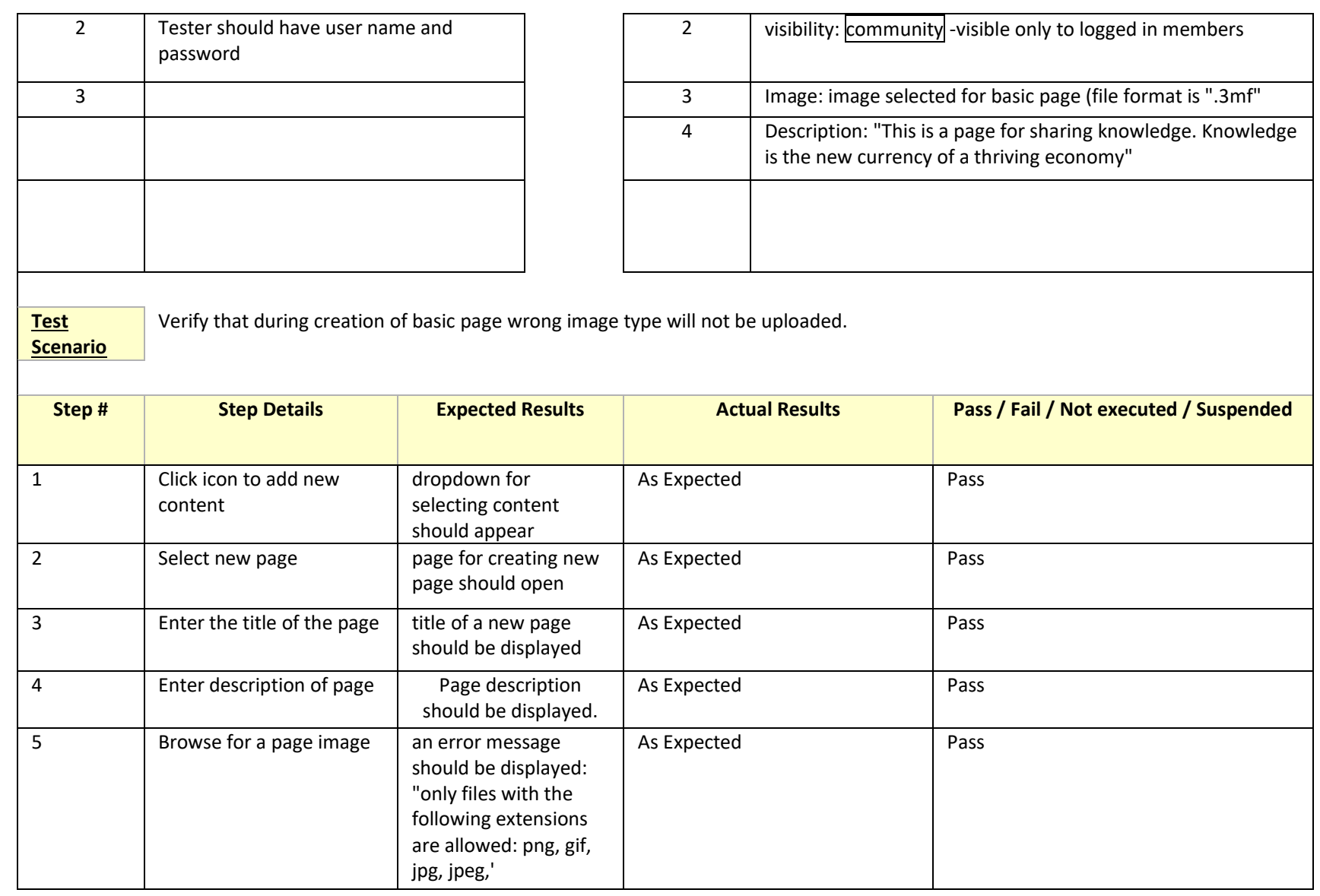

Add content, Create Basic pace

Create Basic page

CONTENT

Tite*

test basic page

The specified file Caboose car $3 \mathrm{mf}$ could not be uploaded.

- Oniy files with the following extensions are allowed: png gif jpg jpeg

- The image file is invalic or the image type is not allowed. Allowed types: png. jpeg.jpg.jpe, gif

image

Choose File No file chosen

9 Upload requirements - Crop your imsge to seiect whien pert of your imoge to show on dieplef.

Figure 47 - test case 4.1 (uploading wrong image file) 


\subsection{Test Case 5: Creation of a profile}

This test case will adjust the profile information of a user. Table 1.16 summarises results for test case 5 on creation of a new profile. See Appendix A.5 for illustrations of this test case.

Table 1.16: creation of a new profile

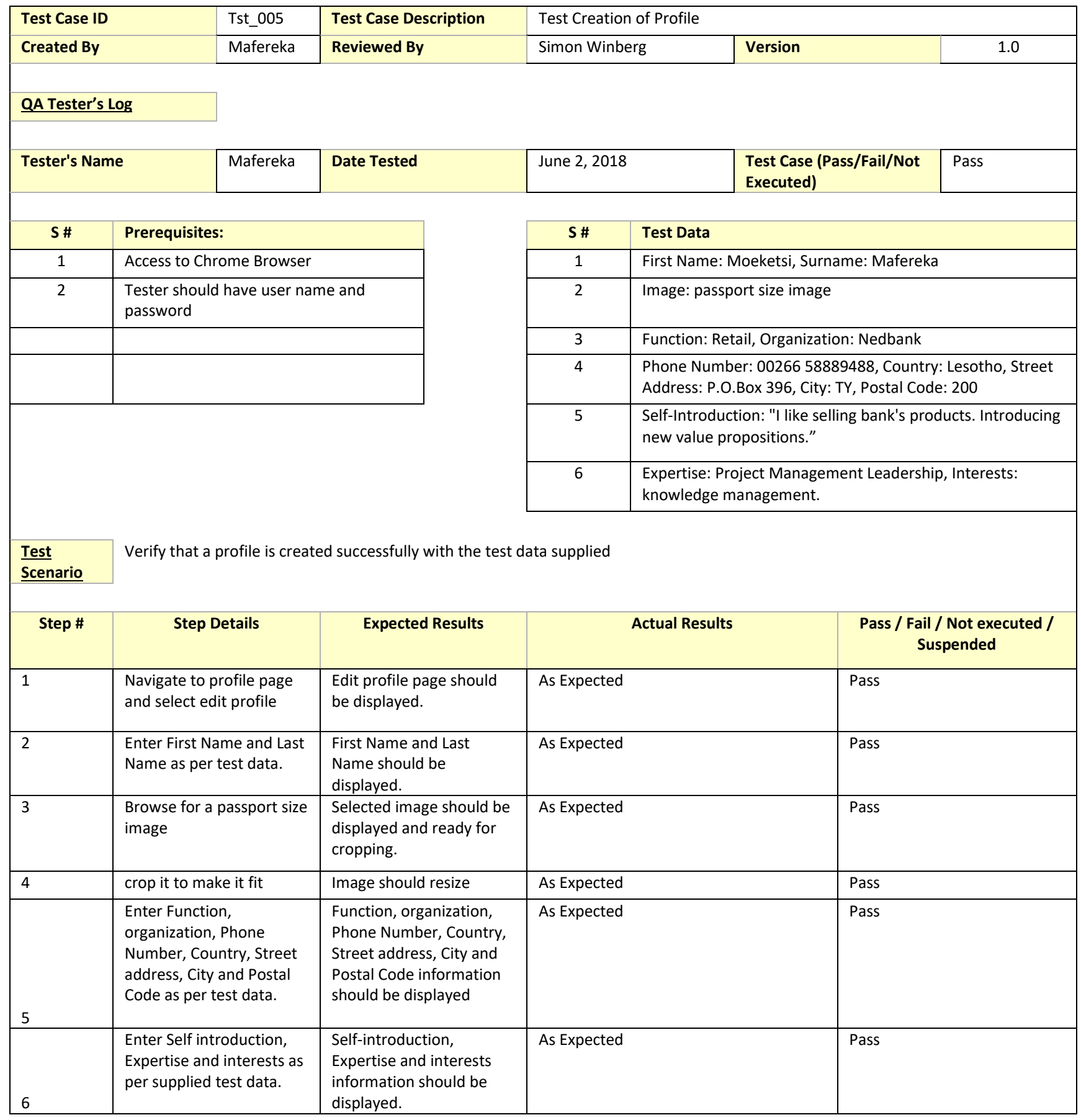




\begin{tabular}{|l|l|l|l|l|}
\hline & Select Save & $\begin{array}{l}\text { Success message should } \\
\text { be displayed and the } \\
\text { profile page should be } \\
\text { updated with newly } \\
\text { entered information. }\end{array}$ & As Expected & Pass \\
7 & & & \\
\hline
\end{tabular}

\subsection{Test Case 6: Creation of a new topic}

This test case explores creation of the new topic with the information provided. Table 1.17 summarises results for this test case. Figure 48 illustrates creating a new topic that was created successfully.

Table 1.17: creation of a new topic

\begin{tabular}{|c|c|c|c|c|c|c|c|}
\hline \multirow{2}{*}{\multicolumn{2}{|c|}{$\begin{array}{l}\text { Test Case ID } \\
\text { Created By }\end{array}$}} & \multirow{2}{*}{$\begin{array}{l}\text { Test Case Description } \\
\text { Reviewed By }\end{array}$} & \multicolumn{5}{|c|}{ Test creation of new topic } \\
\hline & & & & & \multicolumn{2}{|c|}{ Version } & 1.0 \\
\hline \multicolumn{8}{|c|}{$\underline{\text { QA Tester's Log }}$} \\
\hline \multicolumn{2}{|c|}{ Tester's Name } & Date Tested & \multicolumn{2}{|c|}{ June 2, 2018} & \multicolumn{2}{|c|}{$\begin{array}{l}\text { Test Case (Pass/Fail/Not } \\
\text { Executed) }\end{array}$} & Pass \\
\hline S\# & \multicolumn{2}{|l|}{ Prerequisites: } & S\# & \multicolumn{4}{|c|}{ Test Data } \\
\hline 1 & \multicolumn{2}{|l|}{ Access to Chrome Browser } & 1 & \multicolumn{4}{|c|}{ Type of topic: Blog } \\
\hline 2 & \multicolumn{2}{|c|}{$\begin{array}{l}\text { Tester should have user name and } \\
\text { password }\end{array}$} & 2 & \multicolumn{4}{|c|}{ Title of blog: "Block Test" } \\
\hline 3 & & & 3 & \multicolumn{4}{|c|}{ Image: blog image } \\
\hline \multirow[t]{3}{*}{4} & & & 4 & $\begin{array}{l}\text { group } \\
\text { in me }\end{array}$ & visib & munity - visil & only to logged \\
\hline & & & 5 & $\begin{array}{l}\text { Descr } \\
\text { conte }\end{array}$ & $\begin{array}{l}\text { This i } \\
\text { usic" }\end{array}$ & where we st & II be sharing \\
\hline & & & 5 & Attac & None & & \\
\hline $\begin{array}{l}\text { Test } \\
\underline{\text { Scenario }}\end{array}$ & \multicolumn{7}{|c|}{ Verify that a new topic is created successfully with the test data supplied } \\
\hline Step \# & Step Details & Expected Results & \multicolumn{3}{|c|}{ Actual Results } & \multicolumn{2}{|c|}{$\begin{array}{c}\text { Pass / Fail / Not executed / } \\
\text { Suspended }\end{array}$} \\
\hline 1 & $\begin{array}{l}\text { Click icon to add new } \\
\text { content }\end{array}$ & $\begin{array}{l}\text { Dropdown for selecting content } \\
\text { should appear. }\end{array}$ & \multicolumn{3}{|c|}{ As Expected } & \multicolumn{2}{|l|}{ Pass } \\
\hline 2 & Select new topic & $\begin{array}{l}\text { page for creating new topic } \\
\text { should open }\end{array}$ & \multicolumn{3}{|c|}{ As Expected } & \multicolumn{2}{|l|}{ Pass } \\
\hline 3 & $\begin{array}{l}\text { Select type of content as } \\
\text { Blog and enter the title of } \\
\text { the topic as per supplied } \\
\text { test data. }\end{array}$ & $\begin{array}{l}\text { title of a new topic should be } \\
\text { displayed }\end{array}$ & \multicolumn{3}{|c|}{ As Expected } & \multicolumn{2}{|l|}{ Pass } \\
\hline 4 & Browse for a group image & $\begin{array}{l}\text { selected image should be } \\
\text { displayed and ready for } \\
\text { cropping }\end{array}$ & \multicolumn{3}{|c|}{ As Expected } & \multicolumn{2}{|l|}{ Pass } \\
\hline 5 & crop it to make it fit & Image should resize & \multicolumn{3}{|c|}{ As Expected } & \multicolumn{2}{|l|}{ Pass } \\
\hline
\end{tabular}




\begin{tabular}{|l|l|l|l|l|}
\hline 6 & Under Group: select None & "-None-" should be displayed. & As Expected & Pass \\
\hline 7 & $\begin{array}{l}\text { Under Visibility select: } \\
\text { community - visible only } \\
\text { to logged in members. }\end{array}$ & $\begin{array}{l}\text { "Community - visible only to } \\
\text { logged in members." should be } \\
\text { highlighted in red and a radio } \\
\text { button at the beginning of the } \\
\text { phrase. }\end{array}$ & As Expected & Pass \\
\hline 8 & $\begin{array}{l}\text { Enter description of the } \\
\text { blog as per test data. }\end{array}$ & $\begin{array}{c}\text { Blog description should be } \\
\text { displayed. }\end{array}$ & As Expected & Pass \\
\hline 9 & select save & $\begin{array}{l}\text { Success message should be } \\
\text { displayed and the user should } \\
\text { be redirected to newly created } \\
\text { group page. }\end{array}$ & As Expected & Pass \\
\hline
\end{tabular}
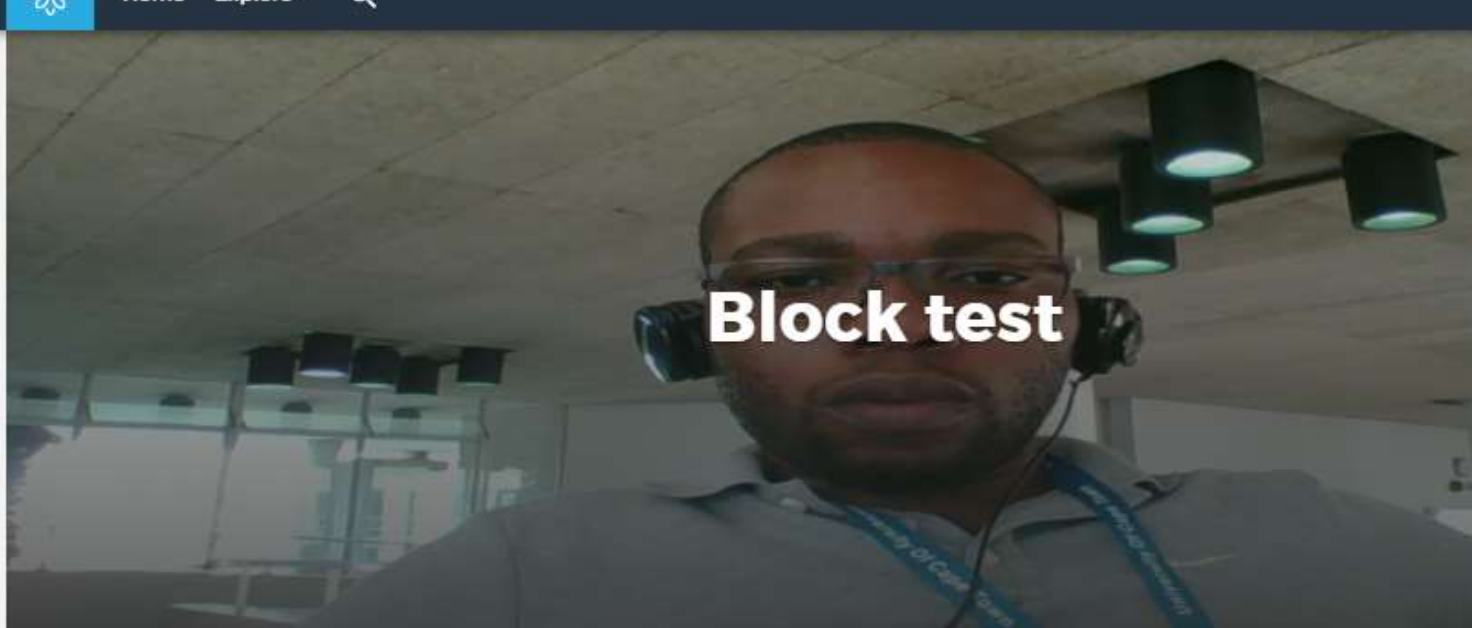

mafereka : 19 June 2018

Blog.

Ocomments

- Olikes

4. community

FOLLOW CONTENT

This is My blog where we shall be sharing content on music.

Oo likes

Figure 48- creation of a new topic (step 9) 


\subsection{System Performance}

This section looks at system performance testing focusing mainly on page loading times. The tests were done using a browser add-on named Page Load time [66]. The network speed when the tests were done is displayed by Figure 49.

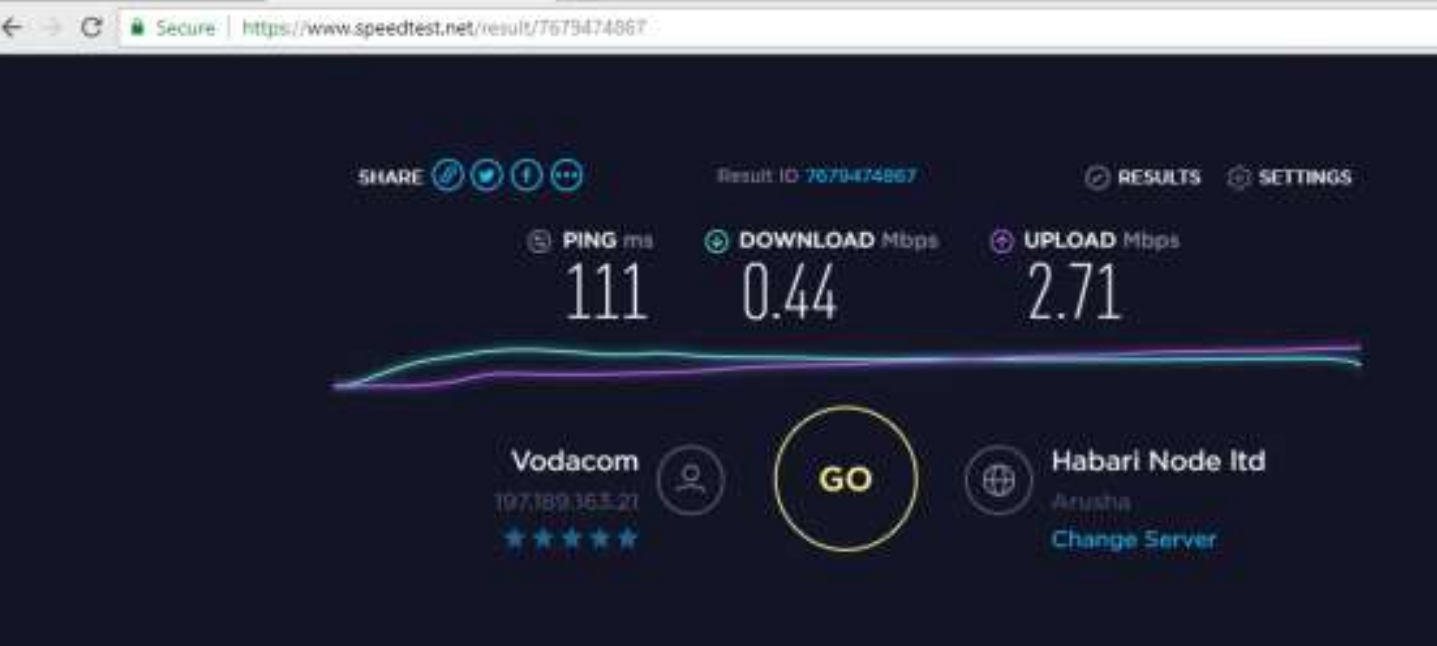

Figure 49 - Network speed

The scenarios that were tested are:
a) Landing Page (before login)
b) Landing Page (after login)
c) Add content in the community
d) Add new event
e) Add new topic
f) Add new group
g) Add new basic page
h) List all groups

Each scenario was performed in the COP website and the results from the Page Load Time Add-on were recorded. Figure 50 displays the results of such tests. 


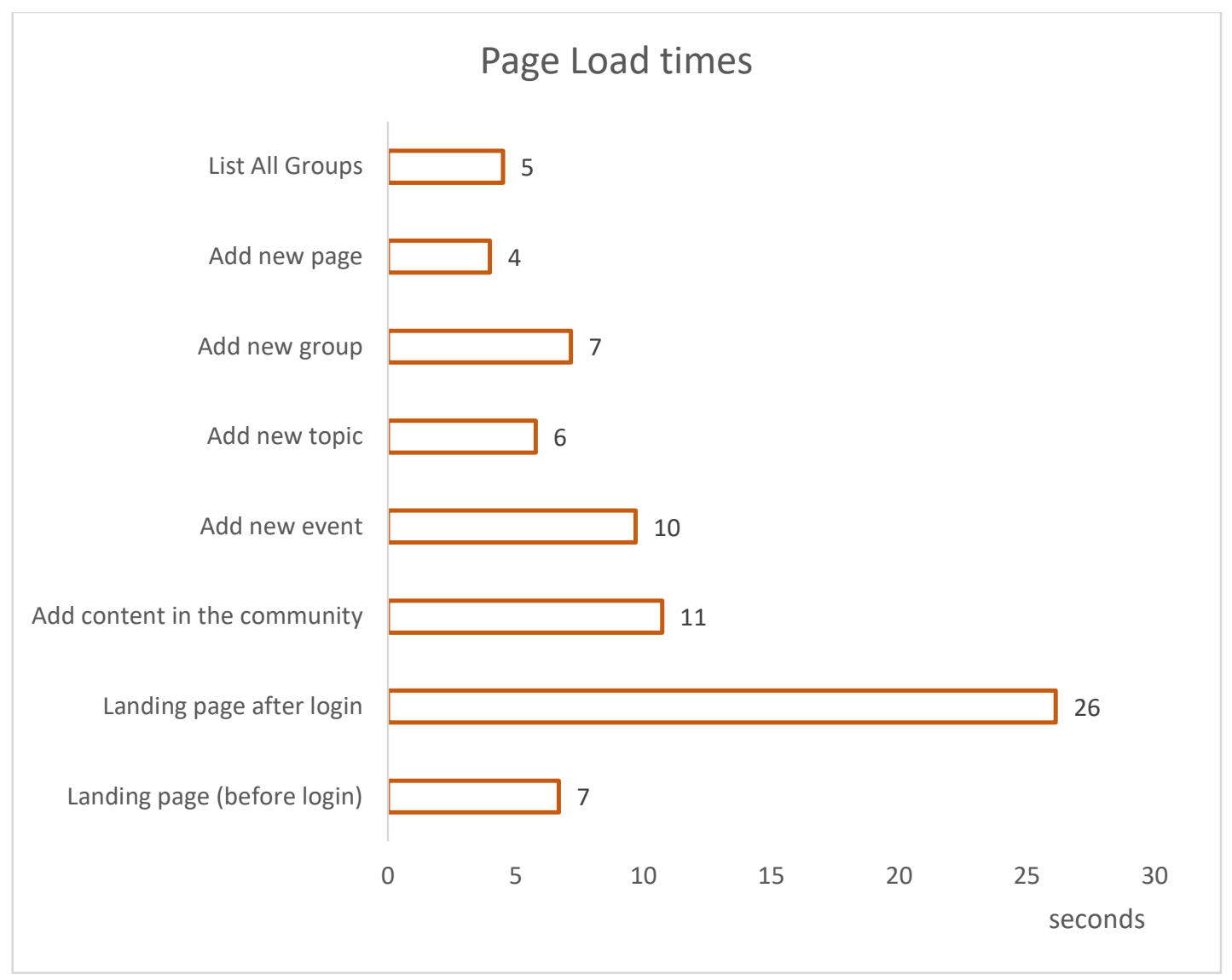

\section{Figure 50 - Page Load times}

The Page Load times are equal or below 10 seconds with an exception of Landing page after login. The reasoning for 26 seconds for page to load after login is because the website loads most of the content that has already been published at this point and such includes large images, posts and comments. The system performance is found to be satisfactory taking into account that pages for other crucial functions take less than 10 seconds to load.

The next section focuses on the conclusions and future work. 


\section{Conclusions and Future Work}

This research project had three objectives to cover, namely: a) Identify the core problem and come up with the solution, b) design, develop and test a solution prototype that will address some of the problems identified, and c) use parts of the Rational unified Process, Prince 2, Systems engineering and software engineering techniques in the research project. All the 3 objectives were covered as the core problem was identified through interviews with employees of the organization under this study and through knowledge management maturity assessment. Requirements were also gathered and defined. It is through this requirements that the prototype was developed and tested.

\subsection{Summary of Main Insights and Concluding Remarks}

The test cases were developed and performed on the prototype COP website. As shown in chapter 6 above, the tests were a success which means that the prototype met the requirements that were being tested.

It is believed that creation of a platform or a tool that enables users to interact, have discussions, create groups, topics, events, and pages is a major contributor to knowledge management. This is because communities of interaction contribute to the amplification and development of new knowledge. The prototype COP website is such a platform with capabilities mentioned above. The prototype is also aligned with SECI Model as it allows for Socialization through interaction of different employees, externalization of knowledge as users share knowledge, combination of knowledge and internalization of knowledge as a user can internalise knowledge after interacting with other employees or users in the platform.

This study showed that knowledge management is one of the key things an organization has to care of. More importantly, to create platforms where different knowledge management processes (knowledge discovery, capturing, sharing and application) can happen.

\subsection{Limitations}

A limitation of this research was the number of respondents that participated in the tests and surveys. This can often be a challenge and limitation of qualitative research where the researcher is attempting to engage with very busy people. Also, the study 
applied quantitative approach through which an online questionnaire was used, and in this case the number of participants that completed the questionnaire was limited. Another limitation was that the prototype was not piloted in the organization under this study due to time limitation. Furthermore, not all the planned requirements were fully developed for this prototype due to time constraints. The performance testing also has limitations in terms of not being tested as widely as was initially expected.

\subsection{Possible areas for future research}

This research work can be further explored to include the functionality that was not completed in the prototype development which was part of the requirements. Such functionality include implementation of the CHAT functionality as a way to facilitating synchronous communication between members of COP.

One area of future research can be around development of the mobile APP for this COP support website. The reason for this is because mobile phones penetration in Africa and around the globe is on the rise. Having surpassed 5 billion people connected to mobile services in 2017 , the global mobile industry will reach further milestones over the next eight years [67]. The number of unique mobile subscribers will reach 5.9 billion by 2025 , equivalent to $71 \%$ of the world's population [67]. Employees carry their cell phones with them and this APP can assist in facilitating synchronous communication anytime anywhere.

Development of the Project Management Module within the COP support website can be explored in the future. The reason for this is because organizations do implement quite a number of projects and it would be of great importance to create functionality where project stakeholders can collaborate, add project plans, add monitoring and evaluation reports, add risk management plans and lessons learnt reports. There could be further project related documentation that can be added to this module.

COP Website's Knowledge Network diagrams to see connectedness between different employees can also be explored. This can help one to see informal networks of how information and knowledge flows within an organization. Also, this can help in facilitation of change management when there are changes within an organization. 


\section{References}

[1] P. M. Senge and A. Kleiner, The Fifth Discipline Fieldbook: Strategies and Tools for Building a Learning Organization, Crown Business, 2014.

[2] G. Ragsdell, "The contribution of Communities of Practice to Project Management," in Encyclopedia if Communities of Practice in Information and Knowledge Management, United States of America, Idea Group, 2006, pp. 104107.

[3] Office of Government Commerce, Managing successful projects with Prince2, United Kingdom: The stationary Office (TSO), 2009.

[4] D. K. Hitchins, Systems Engineering A 21st Century Systems Methodology, England: John Wiley \& Sons Ltd, 2007.

[5] P. Kruchten, Rational Unified Process, The: An Introduction, Third Edition, United States: Addison Wesley, 2003.

[6] M. Mafereka and S. Winberg, "Analysis and development of an online knowledge management support systemfor a community of Practice: Comparing Joomla, Wordpress and Drupal with regard to development of Community of Practice Website," ICISDM '17 Proceedings of the 2017 International conference on Information system and data mining, pp. 6-10, 2017.

[7] W. R. King, "Knowledge Management and Organizational Learning," in knowledge management and organizational learning, New York, Springer Science+Business Media, LLC, 2009, pp. 3-4.

[8] T. H. Davenport and L. .. Prusak, "Working Knowledge: How Organizations manage what they know," An ACM IT magazine and forum, pp. 1-15, 2000. 
[9] I. Becerra-Fernandez and R. Sabherwal, Knowledge Management; systems and processes, 80 Business Park Drive, Armonk, New York: M.E. Sharpe, Inc, 2010.

[10] H. Tsoukas and E. Vladimirou, "What is organizational knowledge," Journal of Management studies, vol. 38, no. 7, 2001.

[11] D. Pritchard, what is this thing called knowledge?, New York City: Routledge, 2014

[12] I. Nonaka and N. Konno, "The concept of Ba: Building a foundation for knowledge creation," Califonia management review, pp. 40-54, 1998.

[13] P. Hildreth, C. Kimble and P. Wright, "communities of practise in the distributed international environment," journal of knowledge management, vol. 4, no. 1, pp. 27-37, 2000.

[14] N. Hara, "Social construction of knowledge in professional communities of practice: tales in the courtrooms," doctoral dersetation, 2000.

[15] R. J. Thierauf, Knowledge Management Systems for Business, Westport, CT: Quorum books, 1999.

[16] Y. M. Yee, C. L. Tan and R. Tharasamy, "Back to basics: building a knowledge management system," STRATEGIC DIRECTION, vol. 35, no. 2, pp. 1-3, 2019.

[17] E. Hajric, Knowledge Management, System and Practices, 2018.

[18] D. G. Schwartz and T. Butler, Encyclopedia of knowledge management, United States of America: Idea Group Inc., 2006, pp. 1-9.

[19] I. Becerra-Fernandez and R. Sabherwal, "Knowledge Management Foundations: Infrastructure, Mechanisms, and Technologies," in Knowledge Management: Systems and Processes, New York, M.E. Sharpe, Inc., 2010, pp. 39-40. 
[20] "Open Social," [Online]. Available: https://www.drupal.org/project/social. [Accessed 1607 2018].

[21] K. Dalkir, Knowledge Management in theory and practice, USA: Elsevier Inc, 2005

[22] M. Alavi and D. E. Leidner, "Review: Knowledge Management and Knowledge Management Systems: conceptual Foundations and Research issues," MIS Quarterly, vol. 25, no. 1, pp. 107-136, 2001.

[23] L. Baker-Eleveth, S. Sarker and D. M. Eveleth, "Formation of an online community of practice: an introductory Study unearthing key elements," Proceedings of the 38th Hawaii international conference on System Sciences, pp. 1-10, 2005.

[24] I. Nonaka, "A Dynamic Theory of Organizational Knowledge Creation," Organization Science, pp. 14-37, 1994.

[25] W. Etienne, "Supporting communities of practice: A survey of communityoriented technologies.," Etienne Wenger, North San Juan, 2001.

[26] N. M. Radziwill, "Implementing Communities of Practice to Manage Knowledge and Drive Innovation," in Knowledge Management Strategies: A handbook of applied technologies, United States of America, Chocolate Avenue Hershey, IGI Global, 2008.

[27] R. Chandra, R. S. Lyer and R. Raman, "enabling organizations to implement smarter, customized social computing platforms by leveraging knowledge flow patterns," Journal of knowledge management, pp. 95-107, 2015.

[28] A. Hemetsberger and C. Reinhardt, "Sharing and Creating Knowledge in OpenSource Communities The case of KDE," The Fifth European Conference on Organizational Knowledge, Learning, and Capabilities, pp. 1-8, 2004. 
[29] L. B. Eveleth, S. Sarker and D. M. Eveleth, "Formation of an Online Community of Practice: An Inductive Study," Formation of an Online Community of Practice: An Inductive Study, pp. 1-10, 2005.

[30] J.-H. Tang and H.-L. Yang, "User role and perception of requirements in a webbased community of practice," Online information review, pp. 499-513, 2005.

[31] K. Patrick, A. Cox and R. Abdullah, "Exploring the selection of technology for enabling communities," in Encyclopedia of communities of practice in information and knowledge management, United States of America, Idea Group Reference (an imprint of Idea Group Inc.), 2006, pp. 166-176.

[32] S. Liao and E.-y. Chou, "Intention to adopt knowledge through virtual communities: posters vs lurkers," Online information review, pp. 442-461, 2012.

[33] M. E. Seliaman, "Exploring the adoption of online discussion forums for knowledge sharing and social rleations among virtual communities," IEEE, 2013.

[34] F. Dotsika, "An IT perspective on supporting communities of practice," in Encyclopedia of communities of practice in information and knowledge management, United States of America, Idea Group Reference (an imprint of Idea Group Inc.), 2006, pp. 257-263.

[35] C. Crosby, "Getting started with Soial Media for Knowledge Management," in Knowledge Management Practice in Organizations, USA, IGI Global, 2014.

[36] H.-J. Choi, J.-C. Ahn, S.-H. Jung and J.-H. Kim, "Communities of practice and knowledge management systems: effects on knowledge management activities and innovation performance," Knowledge management research and practice, 2019.

[37] D. Palacios-Marques, S. Popa and M. P. A. Mari, "The effect of online social media networks and competency-based management on innovation capability," Journal of knowledge management, vol. 20, no. 3, pp. 499-511, 2016. 
[38] N. Hara and K. F. Hew, "knowledge-sharing in an online community of of health-care professionals," information technology and people, vol. 20, no. 3, pp. 235-261, 2007.

[39] E. Bolisani and E. Scarso, "Factors affecting the use of wiki to manage knowledge in a small company," journal of knowledge management, vol. 20, no. 3, pp. 423-443, 2016.

[40] M. Nirav, Choosing an Open Source CMS, Birmingham, B27 6PA, UK.: Packt Publishing Ltd., 2009.

[41] N. Drakos, How to choose the right technology for a knowledge management program, Gartner, Inc, 2014.

[42] R. Ashkenas, "How to preserve institutional knowledge," Harvard business review, 2013.

[43] V. D. Kalkan, "An overall view of knowledge management challenges for global business," Business Process Management Journal, vol. 14, no. 3, pp. 390-400, 2008.

[44] B. Gupta, L. S. lyer and J. E. Aronson, "Knowledge management: practices and challenges," Industrial Management and Data Systems, vol. 100, no. 1, pp. 17$21,2000$.

[45] F. L. Oliva, "Knowledge Management barriers, practices and maturity model," Journal of knowledge Management Vol 18, pp. 1053-1074, 2014.

[46] M. Soakell-Ho and M. D. Myers, "Knowledge management challenges for nongovernment organization: the health and disability sector in New Zealand," VINE, vol. 41, no. 2, pp. 212-228, 2011.

[47] U. de Stricker, Knowledge Management Practice in Organizations, Chocolate Avenue Hershey: IGI Global, 2014. 
[48] S. Henczel, "The information audit as a first step towards effective knowledge management," Knowledge Management Libraries and Librarians Taking Up the challenge, p. 91, 2004.

[49] R. Jochem and H. P. Geers Dennis, "Maturity measurement of knowledgeintensive business processes," The TQM Journal, vol. 23, no. 4, pp. 377-387, 2011.

[50] A. D. Gupta, M. A. Z. M. Arif, C. Egbu, R. O. Walton and R. Islam, "knowledge sharing maturity model for jordanian construction sector," Engineering, construction and architectural Management, vol. 24, no. 1, pp. 170-188, 2017.

[51] N. Khatibian, T. Hasan gholoi pour and H. A. Jafari, "measurement of knowledge management maturity level within organizations," Business Strategy, vol. 11, no. 1, pp. 54-70, 2010.

[52] A. Kossiakoff, W. N. Sweet, S. J. Seymour and S. M. Biemer, Systems Engineering Principles and Practice, New Jersey: John Wiley \& Sons, 2011.

[53] K. Peffers, T. Tuunanen, M. A. Rothenberger and S. Chatterjee, "Design Science Research Methodology for Information Systems Research," Design Science Research Methodology for Information Systems Research, pp. 48-55, 2007;2008.

[54] M. Culligan, S. Marks, T. Nelson, L. Radstone and E. Verzuh, A Guide to the PMD Pro Project Management for Development Professionals, PM4NGOs, 2011.

[55] C. Kothari, Research methodology, methods and Techniques, New Delhi: NEW AGE INTERNATIONAL (P) LIMITED, PUBLISHERS, 2004.

[56] R. Per and H. Martin, "Guidelines for conducting and reporting case study reseach in software engineering," Guidelines for conducting and reporting case study reseach in software engineering, pp. 131-164, 2008. 
[57] C. B. Seaman, "Qualitative Methods in Empirical Studies of software engineering," Qualitative Methods in Empirical Studies of software engineering, pp. 557-572, 1999.

[58] M. D. Myers and N. Michael, "The qualitative interview in IS research: examining the craft," The qualitative interview in IS research: examining the craft, pp. 1-26, 2006.

[59] J. Cropper, E. Berg, M. Culligan and L. Radstone, A Guide to the PMD Pro 1: Project Management for Development Professionals - Level 1, PM4NGOs, 2010.

[60] C. Pope, S. Ziebland and N. Mays, "Analysing qualitative data," Qualitative Research in Health Care, vol. 320, pp. 114-116, 2000.

[61] A. Bryman and R. G. Burges, Analyzing qualitative data, New York: Taylor and Francis Group, 2002.

[62] Roger S. Pressman, Software Engineering,A P R A C T I T I O N E R ' S A P P R O A C H, New York: McGraw-Hill Companies, Inc., 2010.

[63] I. Sommerville, Software Engineering, United States of America: AddisonWesley, 2011.

[64] "Quara," 2017. [Online]. Available: https://www.quora.com/What-are-theadvantages-of-cPanel-hosting. [Accessed 10 2018].

[65] O. Davies and R. Paudyal, "Drupal 8 Systen Requirements," [Online]. Available: https://www.drupal.org/docs/8/system-requirements. [Accessed 1507 2018].

[66] A. Vykhodtsev, "github," GitHub Inc, [Online]. Available: https://github.com/alexvv/chrome-load-timer. [Accessed 08 2018].

[67] "The Mobile economy 2018," 0501 2019. [Online]. Available: www.gsma.com. 
[68] R. Kothari C, Research Methodology, Methods and Techniques, New Delhi: New Age International (P) Limited, Publishers, 2004, p. 97.

[69] K. Lam, "Four innovative ways to create actionable insights from customer data," Retail banking in Asia actionable insights for new opportunities, 2013.

[70] D. Mahadevan, P. Jacobs and S. Bart, "ING's agile transformation," 102016. [Online]. Available: https://www.mckinsey.com/industries/financial-services/ourinsights/ings-agile-transformation.

[71] M. Wessel, "You don't need big data-you need the right data," Havard Business Review, 2016.

[72] S. Williams, Business Intelligence Strategy and big data analytics, USA: Elsevier Inc, 2016.

[73] L. Winig, "A Data-driven approach to customer relationships; a case sudy of Nedbank's Data Practices in South Africa," 10 2016. [Online]. Available: https://shop.sloanreview.mit.edu/store/a-data-driven-approach-to-customerrelationships.

[74] T. Butler, "Anti-foundational knowledge management," in Encyclopedia of knowledge management, USA, Idea Group Reference (an imprint of Idea Group Inc.), 2006, pp. 1-9.

[75] L. Dallemule and T. H. Davenport, "What is your data strategy," Harvard Business Review, 2017.

[76] S. Lee, S. Y. Kim and E. Suh, "Structural health assessment of communities of practice (COPs)," Journal of knowledge management, pp. 1198-1216, 2014. 


\section{Appendix A Test Cases}

\section{A.1 Test Case 1 \\ A.1.1 Test case 1.1}

\begin{tabular}{|c|c|c|c|c|c|c|c|}
\hline \multirow{2}{*}{\multicolumn{2}{|c|}{$\begin{array}{l}\text { Test Case ID } \\
\text { Created By }\end{array}$}} & \multirow{2}{*}{$\begin{array}{l}\text { Tst_001 } \\
\text { Mafereka }\end{array}$} & \multirow{2}{*}{$\begin{array}{l}\text { Test Case Description } \\
\text { Reviewed By }\end{array}$} & \multicolumn{4}{|c|}{ Test the Login Functionality in the COP Website } \\
\hline & & & & \multicolumn{2}{|c|}{ Simon Winberg } & Version & 1.0 \\
\hline \multicolumn{8}{|c|}{ QA Tester's Log } \\
\hline \multicolumn{2}{|c|}{ Tester's Name } & Mafereka & Date Tested & \multicolumn{2}{|c|}{ June 2, 2018} & $\begin{array}{l}\text { Test Case (Pass/Fail/Not } \\
\text { Executed) }\end{array}$ & Pass \\
\hline S\# & \multicolumn{2}{|c|}{ Prerequisites: } & & S\# & \multicolumn{3}{|c|}{ Test Data } \\
\hline 1 & \multicolumn{2}{|c|}{ Access to Chrome Browser } & & 1 & \multicolumn{3}{|c|}{ Userid = mafereka } \\
\hline 2 & & & & 2 & \multicolumn{3}{|c|}{ Pass $=$ Maf3r3ka } \\
\hline 3 & & & & 3 & & & \\
\hline 4 & & & & 4 & & & \\
\hline
\end{tabular}

Test Verify on entering valid userid and password, the customer can login $\underline{\text { Scenario }}$

\begin{tabular}{|c|l|l|l|l|}
\hline Step \# & \multicolumn{1}{|c|}{ Step Details } & \multicolumn{1}{|c|}{ Expected Results } & \multicolumn{1}{c|}{$\begin{array}{c}\text { Actual Results } \\
\text { Pass / Fail / Not } \\
\text { executed / Suspended }\end{array}$} \\
\hline 1 & $\begin{array}{l}\text { Navigate to } \\
\text { http://mafcop.co.Is/DIR2/html/ }\end{array}$ & Site should open & As Expected & Pass \\
\hline 2 & Enter Userid \& Password & Credential can be entered & As Expected & Pass \\
\hline 3 & Click Submit & Customer is logged in & As Expected & Pass \\
\hline
\end{tabular}



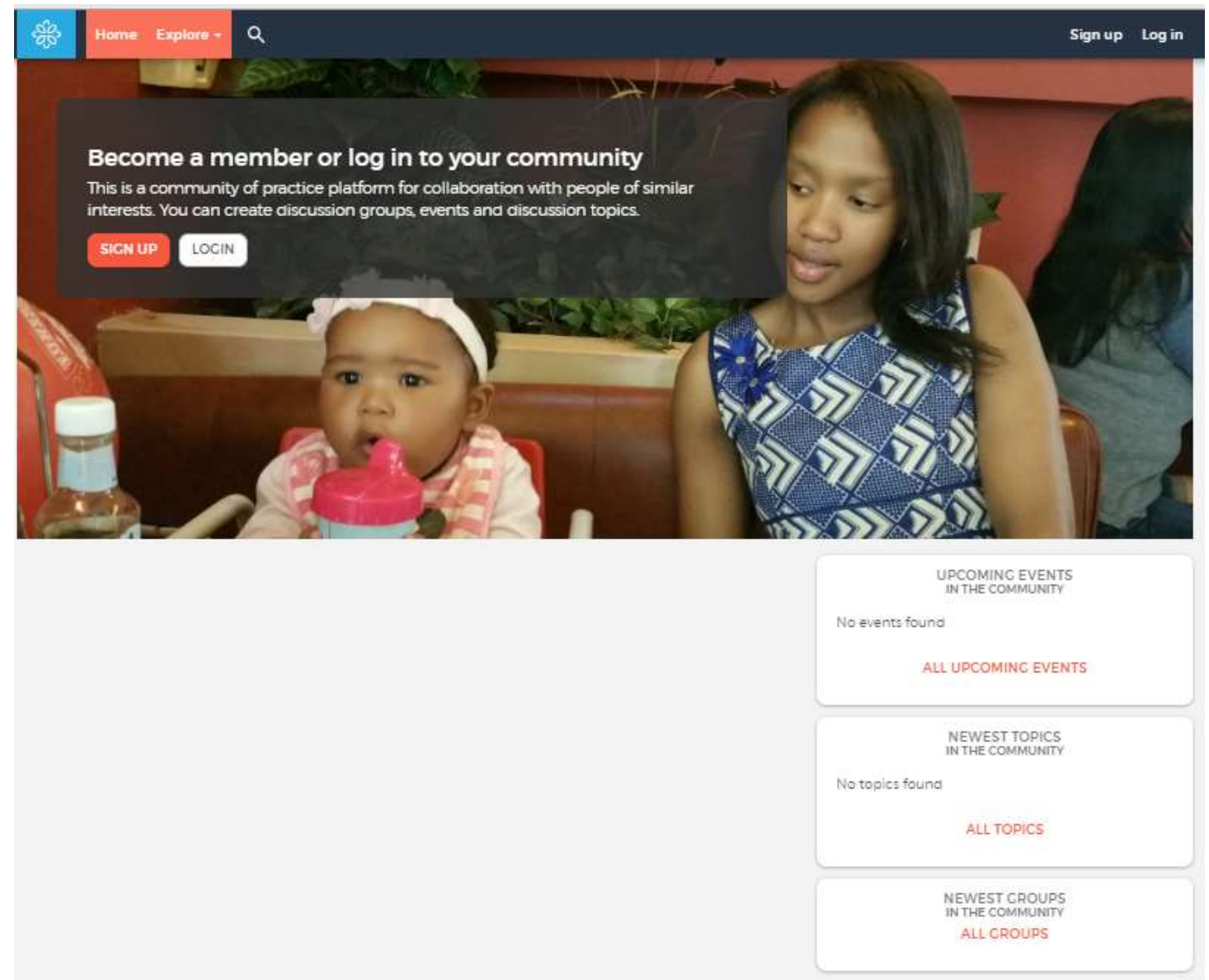

Home Explore - Q

$\log$ in

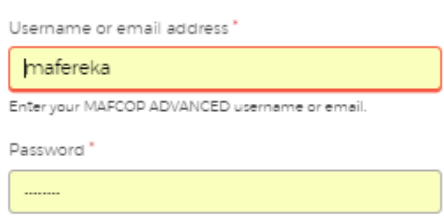

Forgot password? 


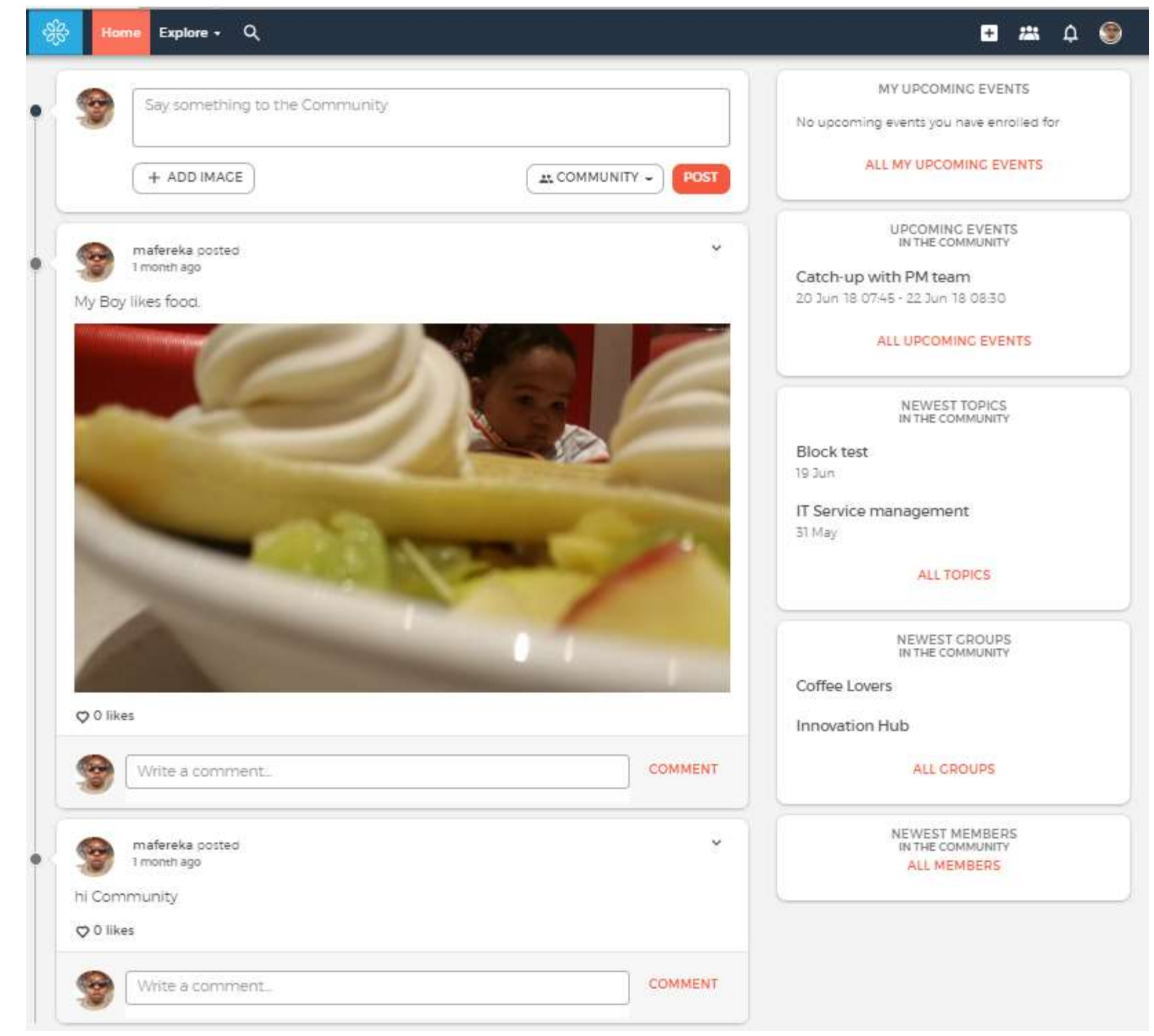


A.1.2 Test Case 1.2

\begin{tabular}{|c|c|c|c|c|c|c|c|c|}
\hline \multirow{2}{*}{\multicolumn{2}{|c|}{$\begin{array}{l}\text { Test Case ID } \\
\text { Created By }\end{array}$}} & \multirow{2}{*}{$\begin{array}{l}\text { Tst_0011 } \\
\text { Mafereka }\end{array}$} & \multirow{2}{*}{$\begin{array}{l}\text { Test Case Description } \\
\text { Reviewed By }\end{array}$} & \multicolumn{5}{|c|}{ Test the Login Functionality in the COP Website } \\
\hline & & & & \multicolumn{2}{|c|}{ Simon Winberg } & \multicolumn{2}{|c|}{ Version } & 1.0 \\
\hline \multicolumn{9}{|c|}{ QA Tester's Log } \\
\hline \multicolumn{2}{|l|}{ Tester's Name } & Mafereka & Date Tested & June 2 , & & \multicolumn{2}{|c|}{$\begin{array}{l}\text { Test Case (Pass/Fail/Not } \\
\text { Executed) }\end{array}$} & Pass \\
\hline S \# & \multicolumn{3}{|l|}{ Prerequisites: } & S \# & \multicolumn{4}{|c|}{ Test Data } \\
\hline 1 & \multicolumn{3}{|c|}{ Access to Chrome Browser } & 1 & \multicolumn{4}{|c|}{ Userid = mafereka } \\
\hline 2 & & & & 2 & \multicolumn{4}{|c|}{ Pass = Maf3r3ka } \\
\hline 3 & & & & 3 & & & & \\
\hline 4 & & & & 4 & & & & \\
\hline $\begin{array}{l}\text { Test } \\
\text { Scenario }\end{array}$ & \multicolumn{8}{|c|}{ Verify on entering a wrong userid and password, the customer cannot login } \\
\hline Step \# & \multicolumn{2}{|c|}{ Step Details } & Expected Results & \multicolumn{3}{|c|}{ Actual Results } & \multicolumn{2}{|c|}{$\begin{array}{l}\text { Pass / Fail / Not executed } \\
\text { / Suspended }\end{array}$} \\
\hline 1 & \multicolumn{2}{|c|}{$\begin{array}{l}\text { Navigate to } \\
\text { http://mafcop.co.Is/DIR2/html/ }\end{array}$} & Site should open & \multicolumn{3}{|c|}{ As Expected } & \multicolumn{2}{|l|}{ Pass } \\
\hline 2 & \multicolumn{2}{|c|}{ Enter Userid \& Password } & Credential can be entered & \multicolumn{3}{|c|}{ As Expected } & \multicolumn{2}{|l|}{ Pass } \\
\hline 3 & \multicolumn{2}{|l|}{ Click Submit } & $\begin{array}{l}\text { Customer should not be } \\
\text { logged in }\end{array}$ & \multicolumn{3}{|c|}{ As Expected } & \multicolumn{2}{|l|}{ Pass } \\
\hline
\end{tabular}

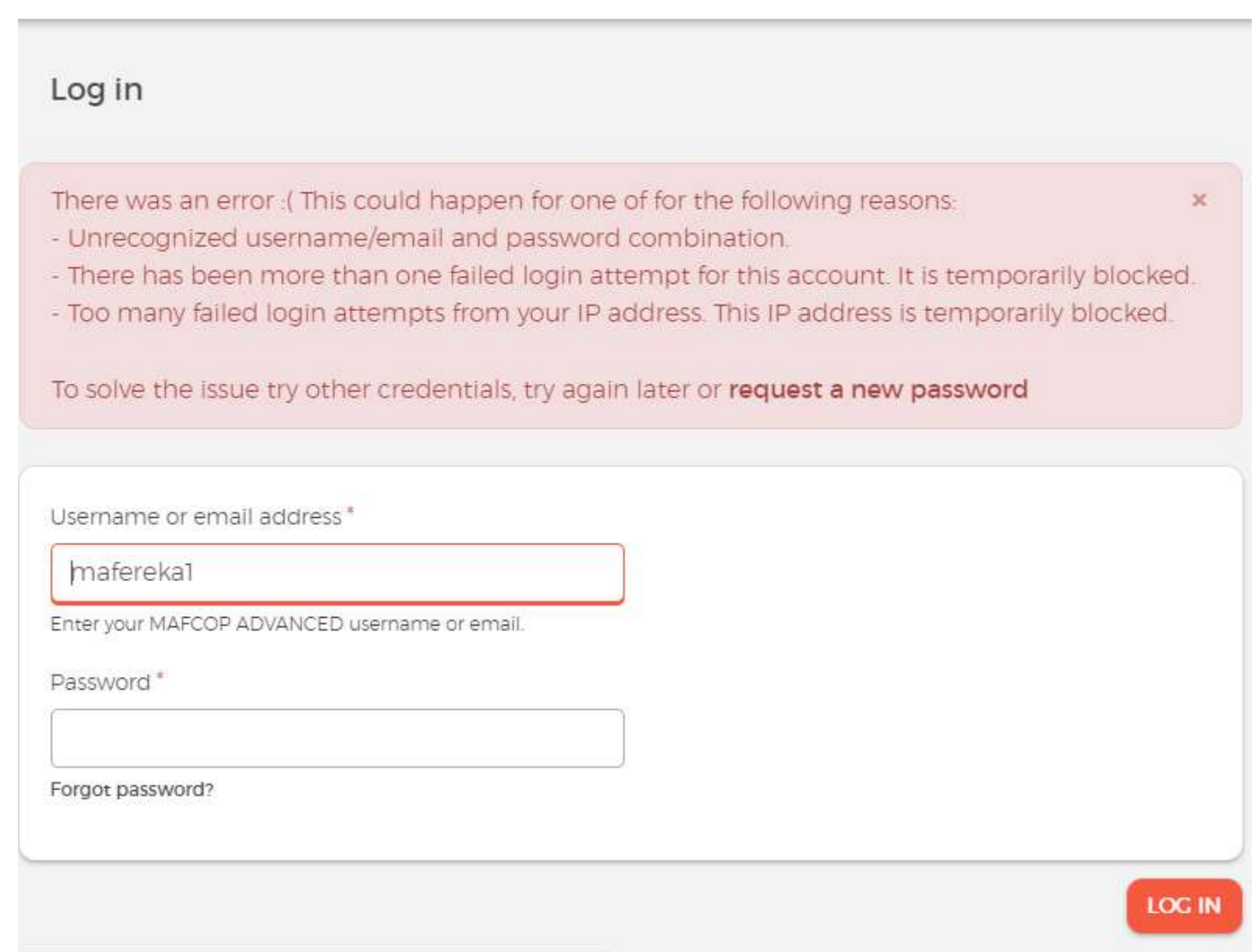




\section{A.2 Test Case 2}

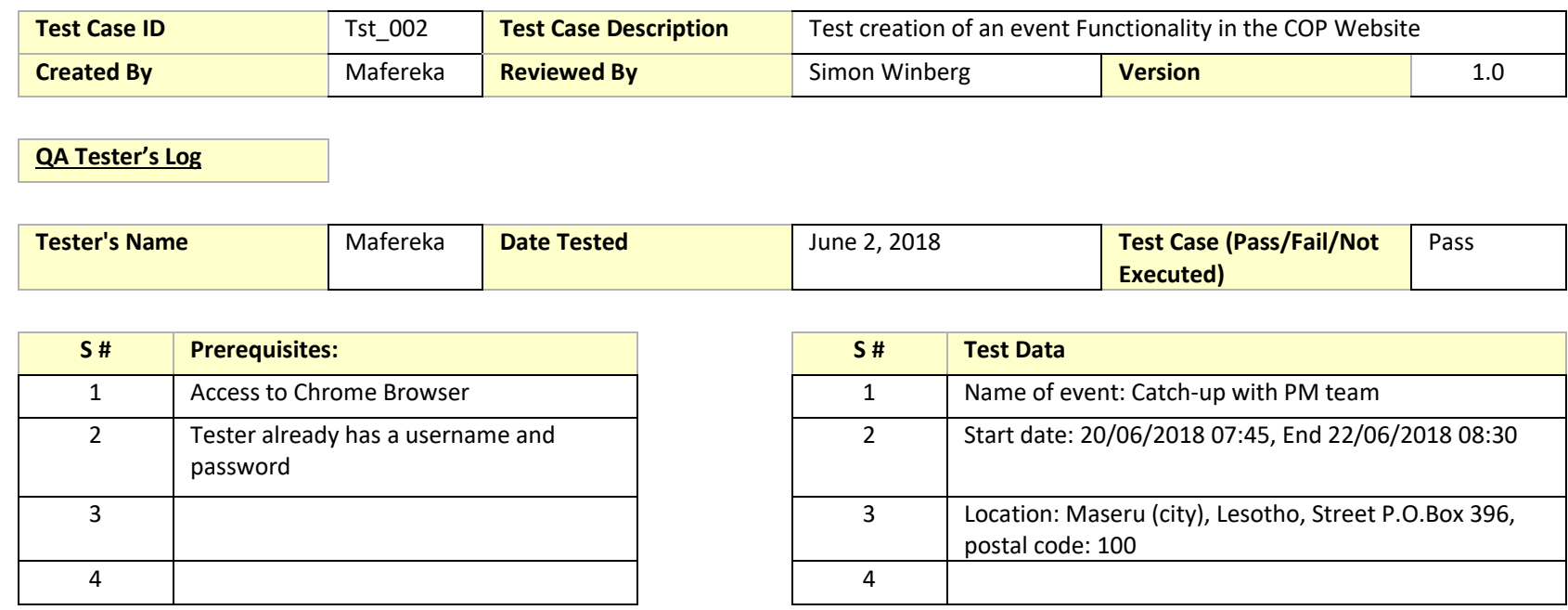

Test create an event using test data

$\underline{\text { Scenario }}$

\begin{tabular}{|c|c|c|c|c|}
\hline Step \# & Step Details & Expected Results & Actual Results & $\begin{array}{l}\text { Pass / Fail / Not executed } \\
\text { / Suspended }\end{array}$ \\
\hline 1 & $\begin{array}{l}\text { Click icon to add new } \\
\text { content }\end{array}$ & $\begin{array}{l}\text { dropdown for selecting } \\
\text { content should appear }\end{array}$ & As Expected & Pass \\
\hline 2 & Select new event & $\begin{array}{l}\text { page for creating new } \\
\text { event should open }\end{array}$ & As Expected & Pass \\
\hline 3 & $\begin{array}{l}\text { enter the title of the } \\
\text { event }\end{array}$ & title should be displayed & As Expected & Pass \\
\hline 4 & $\begin{array}{l}\text { browse for an event } \\
\text { image }\end{array}$ & $\begin{array}{l}\text { selected image should be } \\
\text { displayed and ready for } \\
\text { cropping }\end{array}$ & As Expected & Pass \\
\hline 5 & crop it to make it fit & image should resize & As Expected & Pass \\
\hline 6 & enter start and end date & $\begin{array}{l}\text { the dates and time should } \\
\text { be displayed }\end{array}$ & As Expected & Pass \\
\hline 7 & enter Location details & $\begin{array}{l}\text { Location settings should } \\
\text { be displayed. }\end{array}$ & As Expected & Pass \\
\hline 8 & Enter description of event & $\begin{array}{l}\text { Description of the event } \\
\text { should be displayed. }\end{array}$ & As Expected & Pass \\
\hline
\end{tabular}




\begin{tabular}{|r|c|l|l|l|}
\cline { 2 - 5 } & attach files for an event & $\begin{array}{l}\text { Icon for attached files and } \\
\text { description of such files } \\
\text { should be displayed. }\end{array}$ & As Expected & Pass \\
\hline 9 & select save & $\begin{array}{l}\text { Success message should } \\
\text { be displayed and the user } \\
\text { should be redirected to } \\
\text { newly created event } \\
\text { page. }\end{array}$ & As Expected & Pass \\
\hline
\end{tabular}

Test Case 2 Images:

\section{Home Explore - Q}

Add content, Create Event

\section{Create Event}

\section{TITLE \& IMACE}

Titie *

Catch-up with PM team

\section{Image}

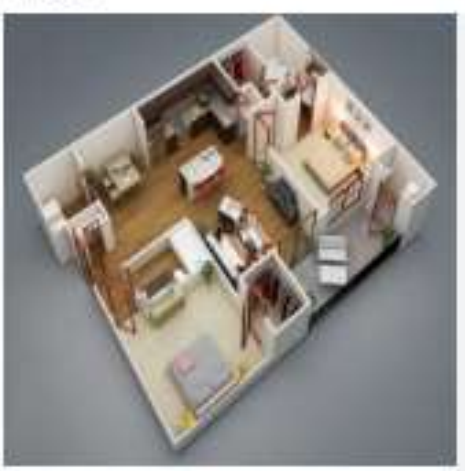

Alternative text

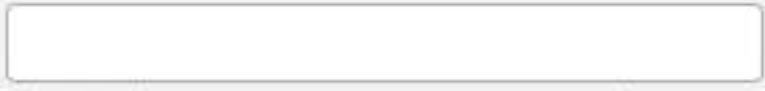

This text wil be used oy screen readers search engines, or when the image cannot oeloaded.

Dim 2-oedroom-house-planjpg

age

\section{REMOVE}

\section{- CROP IMACE (CROPPINC APPLIED)}

\section{Large}

Small

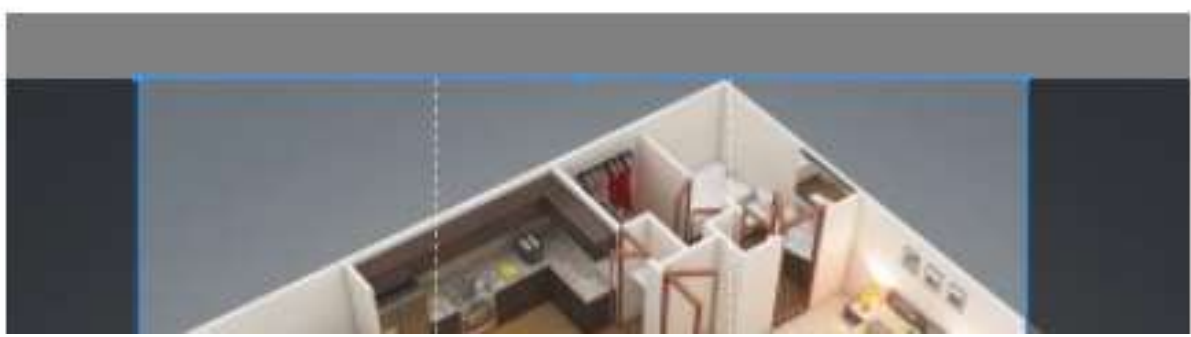




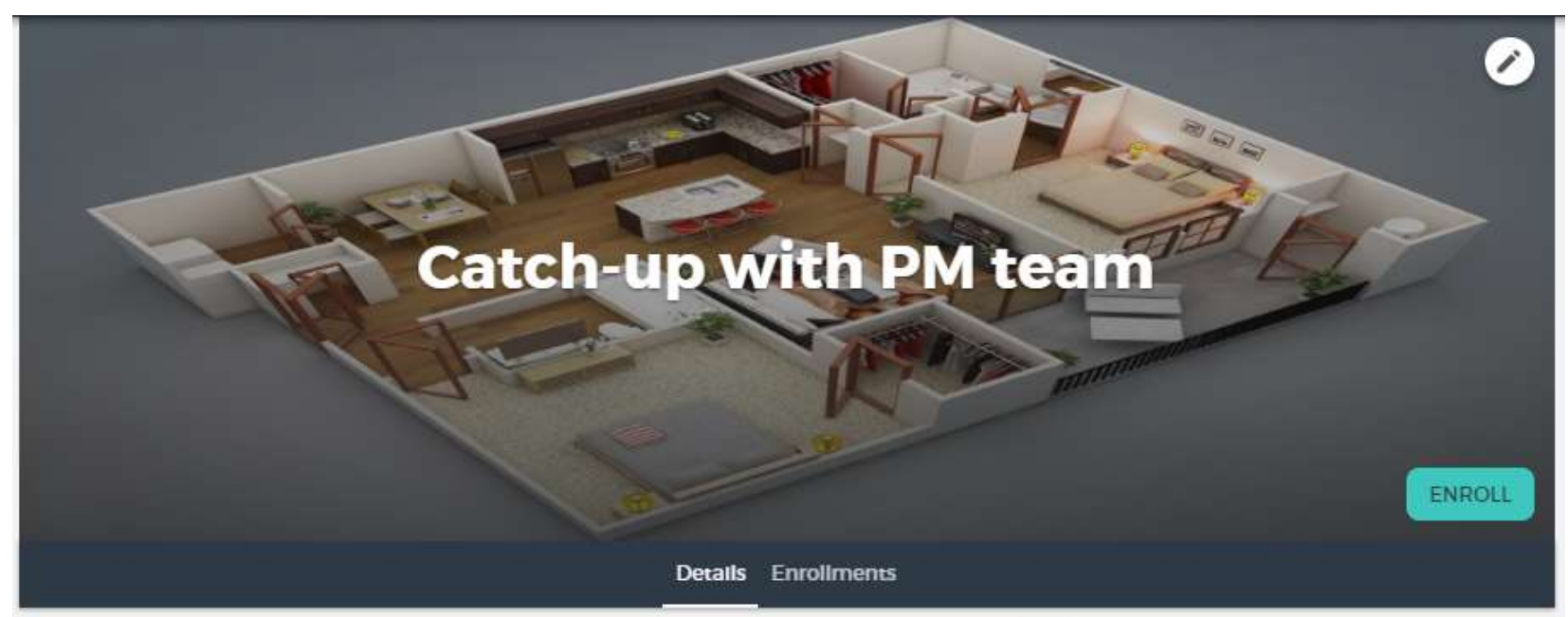

- The crop "Small" was successfully added for image "2-bedroom-house-plan.jpg" - Event Catch-up with PM team has been created

(1) Jun ' 18 07:45 - 22 Jun ' 18 08:30

- Maseru - P.O.Box 396, Maseru, 100, Lesotho 
DESCRIPTION

Body*

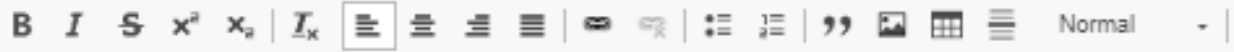

(1) 回 Source

test

body $\mathrm{p}$

ATTACHMENTS

SHOW ROW WEICHTS

FILE INFORMATION

OPERATIONS

* Rat testfile.tort 0 bytes REMOVE

Description

The description may be used as the label of the link to the file.

Add a new file 
LOCATION

Location name

Maseru

Country

\begin{tabular}{|l|l|}
\hline Lesotho & Q \\
\hline
\end{tabular}

Street address

P.O.BOX 396

City

Postal code

Maseru

100

DATE \& TIME

START

\begin{tabular}{lll} 
Date & Time \\
\hline $2018-06-20$ & $07: 45$ & (1) \\
\hline
\end{tabular}

END

Date Time

2018-06-22

$08: 30$

(1) 
(39) mafereka- 18 June 2018

(120 Jun '18 07:45 - 22 Jun ' $1808: 30$

- Maseru -P.OBox 396. Maseru. 100. Lesotho

- Ocomments Olikes A community

FOLLOW CONTENT

test

Files

testfile txt:

Etalbytes

○ likes

Comments (0) 


\section{A.3 Test Case 3}

\begin{tabular}{|c|c|c|c|c|c|c|c|}
\hline \multirow{2}{*}{\multicolumn{2}{|c|}{$\begin{array}{l}\text { Test Case ID } \\
\text { Created By }\end{array}$}} & \multirow{2}{*}{$\begin{array}{l}\text { Tst_003 } \\
\text { Mafereka }\end{array}$} & \multirow{2}{*}{$\begin{array}{l}\text { Test Case Description } \\
\text { Reviewed By }\end{array}$} & \multicolumn{4}{|c|}{ Test creation of a new group } \\
\hline & & & & \multicolumn{2}{|c|}{ Simon Winberg } & Version & 1.0 \\
\hline \multicolumn{8}{|c|}{ QA Tester's Log } \\
\hline \multicolumn{2}{|c|}{ Tester's Name } & Mafereka & Date Tested & \multicolumn{2}{|c|}{ June 2, 2018} & $\begin{array}{l}\text { Test Case (Pass/Fail/Not } \\
\text { Executed) }\end{array}$ & Pass \\
\hline S \# & \multicolumn{3}{|c|}{ Prerequisites: } & S \# & \multicolumn{3}{|c|}{ Test Data } \\
\hline 1 & \multicolumn{3}{|c|}{ Access to Chrome Browser } & 1 & \multicolumn{3}{|c|}{ type of group: open } \\
\hline 2 & \multicolumn{3}{|c|}{$\begin{array}{l}\text { Tester already has a username and } \\
\text { password }\end{array}$} & 2 & \multicolumn{3}{|c|}{$\begin{array}{l}\text { Name of group: coffee Lovers, description: "This is a group } \\
\text { for bringing together different coffee lovers" }\end{array}$} \\
\hline 3 & & & & 3 & \multicolumn{3}{|c|}{ a photo of coffee container } \\
\hline 4 & & & & 4 & \multicolumn{3}{|c|}{ Location: Cape town, South Africa } \\
\hline
\end{tabular}

\begin{tabular}{|l|l}
\hline Test & Create a group using the test data \\
\hline Scenario &
\end{tabular}

\begin{tabular}{|c|c|c|c|c|}
\hline Step \# & Step Details & Expected Results & Actual Results & $\begin{array}{c}\text { Pass / Fail / Not executed / } \\
\text { Suspended }\end{array}$ \\
\hline 1 & $\begin{array}{l}\text { Click icon to add new } \\
\text { content }\end{array}$ & $\begin{array}{l}\text { dropdown for selecting } \\
\text { content should appear }\end{array}$ & As Expected & Pass \\
\hline 2 & Select new group & $\begin{array}{l}\text { page for creating new } \\
\text { group should open }\end{array}$ & As Expected & Pass \\
\hline 3 & $\begin{array}{l}\text { enter the title of the } \\
\text { group }\end{array}$ & $\begin{array}{l}\text { title of a new group } \\
\text { should be displayed }\end{array}$ & As Expected & Pass \\
\hline 4 & $\begin{array}{l}\text { Enter description of } \\
\text { group }\end{array}$ & $\begin{array}{l}\text { Group description should } \\
\text { be displayed. }\end{array}$ & As Expected & Pass \\
\hline 5 & Browse for a group image & $\begin{array}{l}\text { selected image should be } \\
\text { displayed and ready for } \\
\text { cropping }\end{array}$ & As Expected & Pass \\
\hline 6 & crop it to make it fit & Image should resize & As Expected & Pass \\
\hline 7 & Enter Location details & $\begin{array}{l}\text { Location settings should } \\
\text { be displayed. }\end{array}$ & As Expected & Pass \\
\hline 8 & select save & $\begin{array}{l}\text { Success message should } \\
\text { be displayed and the user } \\
\text { should be redirected to } \\
\text { newly created group } \\
\text { page. }\end{array}$ & As Expected & Pass \\
\hline
\end{tabular}




\section{Test Case 3 Images:}

Add group > Add Open group

\section{Add Open group}

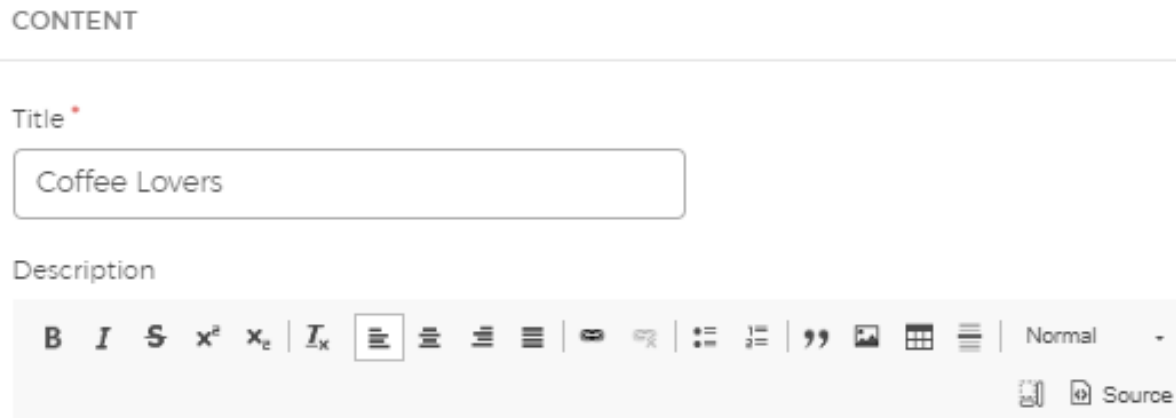

This is a group for bringing together different coffee lovers 


\section{Add group}

SETTINCS

Croup type

Public group

This is a public group. Users may join without approval and all content added in this group will be visible to all community members and anonymous users.

Open group

This is an open group. Users may join without approval and all content added in this group will be visible to all community members.

Closed group

This is a closed group. Users can only join by invitation and all content added in this group will be hidden for non members. Can not be changed once a group is createc. 
Croup Image

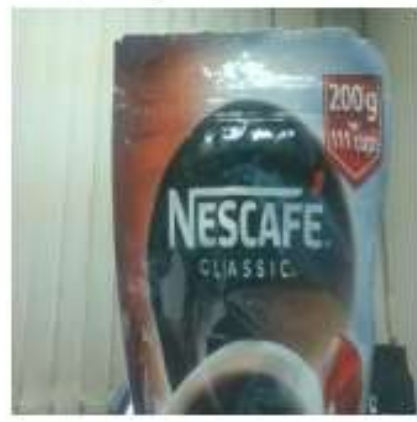

Alternative text

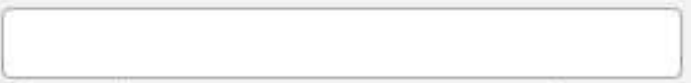

This text will be used oy screen readers, search engines, or when the image cannot oe loaded.

Eim WIN_20180619_20_54_58_Pro.jog

$157.62 \times B$

age

REMOVE

ฟ CROPIMACE (CROPPINC APPLIED)

Large

Small

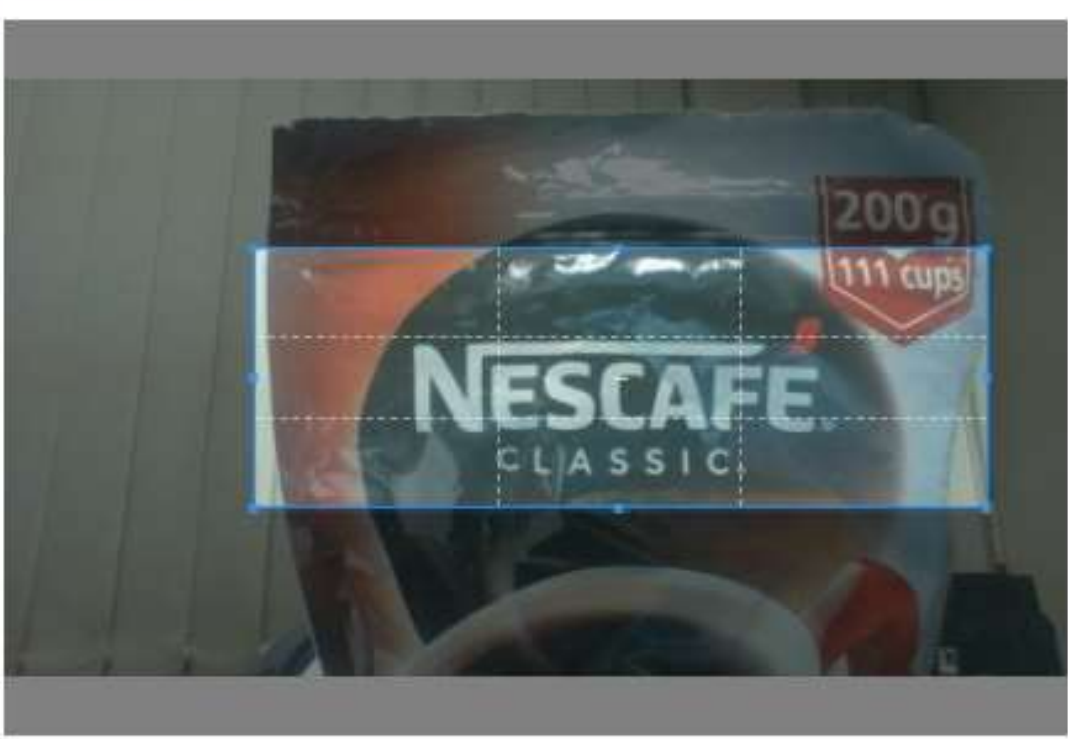

RESET CROP 


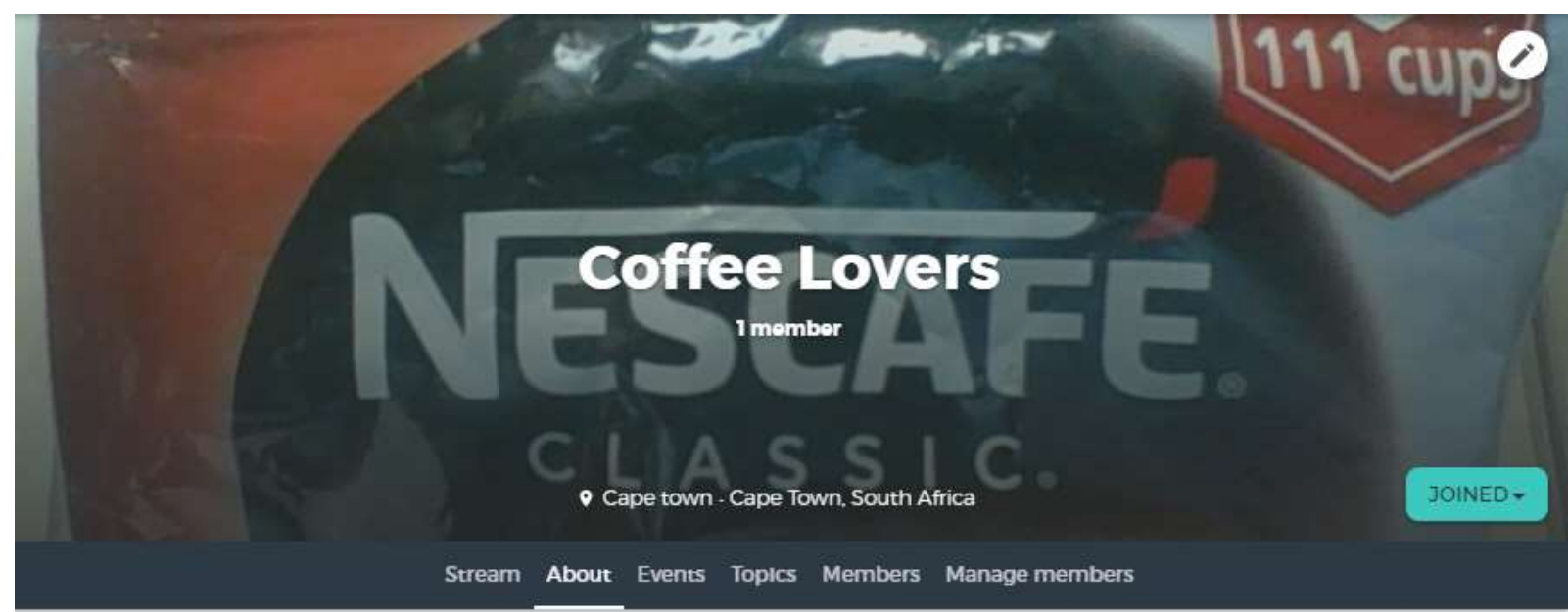

- The crop "Large" was successfully added for image

WIN_20180619_20_54_58_Projpg"

- Open group Coffee Lovers has been created

CROUP MANACERS

UPCOMINC EVENTS
IN THE GROUP

No upcoming events in this group

ALL UPCOMINC EVENTS

NEWEST TOPICS
IN THE CROUP

mafereka

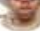

inge

No topics in this group

LOCATION

Location name

Cape town

Country

\begin{tabular}{|l|l|}
\hline South Africa & ? \\
\hline
\end{tabular}

Street address

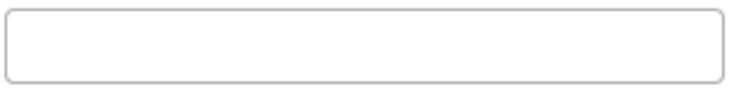

City

Cape Town

Postal cocle 


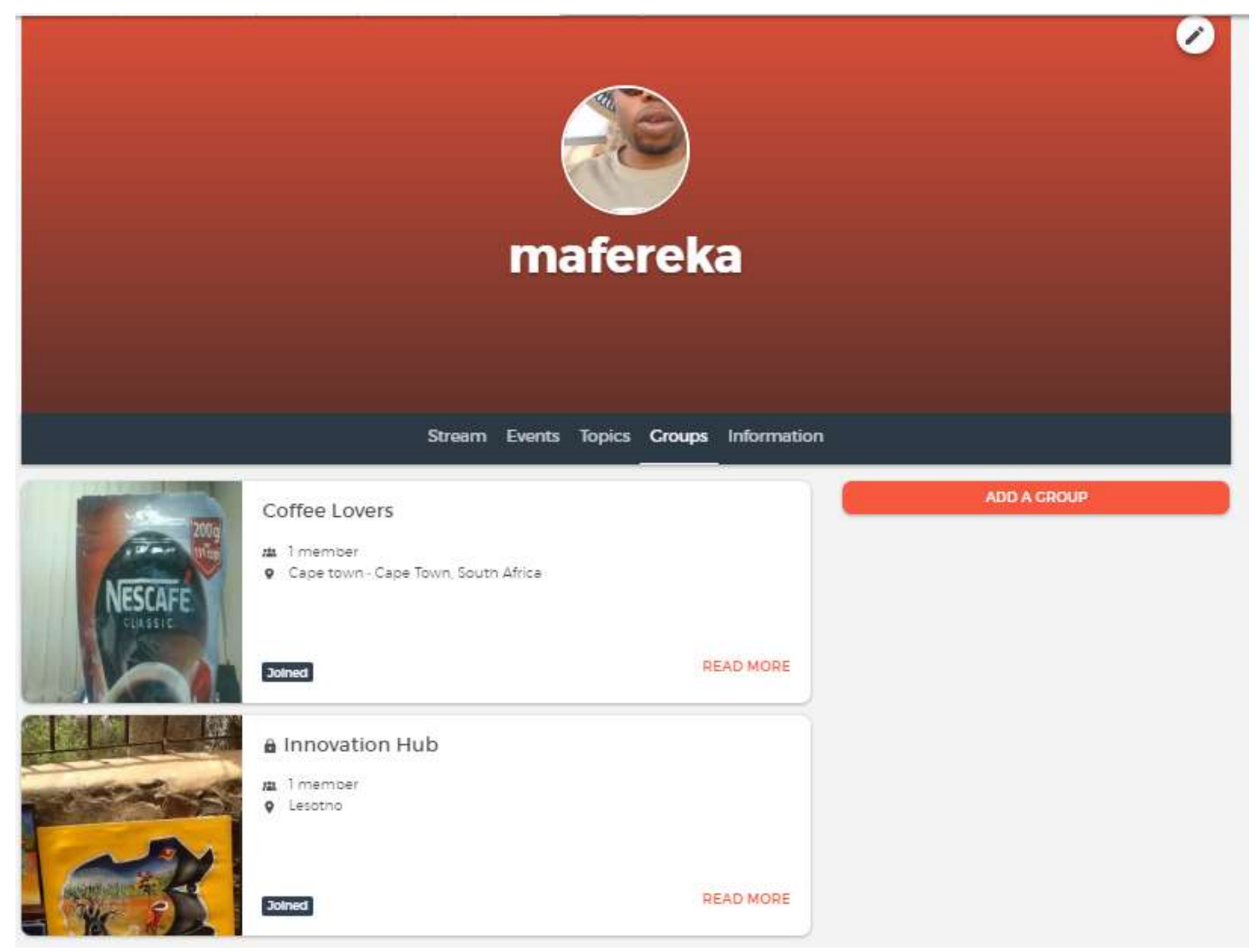




\section{A.4 Test Case 4 (creation of a basic page)}

\begin{tabular}{|c|c|c|c|c|c|c|c|}
\hline \multirow{2}{*}{\multicolumn{2}{|c|}{$\begin{array}{l}\text { Test Case ID } \\
\text { Created By }\end{array}$}} & \multirow{2}{*}{$\begin{array}{l}\text { Tst_004 } \\
\text { Mafereka }\end{array}$} & \multirow{2}{*}{$\begin{array}{l}\text { Test Case Description } \\
\text { Reviewed By }\end{array}$} & \multicolumn{4}{|c|}{ Creation of a basic page } \\
\hline & & & & \multicolumn{2}{|c|}{ Simon Winberg } & Version & 1.0 \\
\hline \multicolumn{8}{|c|}{ QA Tester's Log } \\
\hline \multicolumn{2}{|c|}{ Tester's Name } & Mafereka & Date Tested & \multicolumn{2}{|c|}{ June 2,2018} & $\begin{array}{l}\text { Test Case (Pass/Fail/Not } \\
\text { Executed) }\end{array}$ & Pass \\
\hline S \# & \multicolumn{3}{|c|}{ Prerequisites: } & $\begin{array}{l}\text { S } \\
\#\end{array}$ & \multicolumn{3}{|l|}{ Test Data } \\
\hline 1 & \multicolumn{3}{|c|}{ Access to Chrome Browser } & 1 & \multicolumn{3}{|c|}{ Title of a page: "knowledge" } \\
\hline 2 & \multicolumn{3}{|c|}{ Tester should have user name and password } & 2 & \multicolumn{3}{|c|}{ visibility: community -visible only to logged in members } \\
\hline \multirow[t]{3}{*}{3} & & & & 3 & \multicolumn{3}{|c|}{ Image: image selected for basic page. } \\
\hline & & & & 4 & \multicolumn{3}{|c|}{$\begin{array}{l}\text { Description: "This is a page for sharing knowledge. } \\
\text { Knowledge is the new currency of a thriving economy" }\end{array}$} \\
\hline & & & & 5 & \multicolumn{3}{|c|}{$\begin{array}{l}\text { files: a) motivation.txt, file description: " Motivation" } \\
\text { b) Get-Your-financial-house-on-order.pdf: description: } \\
\text { Financial Fitness }\end{array}$} \\
\hline
\end{tabular}

Test Verify that a basic page is created successfully with the test data supplied $\underline{\text { Scenario }}$

\begin{tabular}{|c|c|c|c|c|}
\hline Step \# & Step Details & Expected Results & Actual Results & $\begin{array}{c}\text { Pass / Fail / Not executed / } \\
\text { Suspended }\end{array}$ \\
\hline 1 & Click icon to add new content & $\begin{array}{l}\text { dropdown for selecting content } \\
\text { should appear }\end{array}$ & As Expected & Pass \\
\hline 2 & Select new page & $\begin{array}{l}\text { page for creating new page } \\
\text { should open }\end{array}$ & As Expected & Pass \\
\hline 3 & Enter the title of the page & $\begin{array}{l}\text { title of a new page should be } \\
\text { displayed }\end{array}$ & As Expected & Pass \\
\hline 4 & Enter description of page & $\begin{array}{l}\text { Page description should be } \\
\text { displayed. }\end{array}$ & As Expected & Pass \\
\hline 5 & Browse for a page image & $\begin{array}{l}\text { selected image should be } \\
\text { displayed and ready for cropping }\end{array}$ & As Expected & Pass \\
\hline 6 & crop it to make it fit & Image should resize & As Expected & Pass \\
\hline 7 & $\begin{array}{l}\text { Under a new file: select choose } \\
\text { file and navigate to } \\
\text { motivation.txt }\end{array}$ & $\begin{array}{l}\text { The file should be uploaded and } \\
\text { its icon should be displayed }\end{array}$ & As Expected & Pass \\
\hline 8 & $\begin{array}{l}\text { Under file information, } \\
\text { Description, type "Motivation" }\end{array}$ & $\begin{array}{l}\text { Attachment description: } \\
\text { "Motivation" should be displayed. }\end{array}$ & As Expected & Pass \\
\hline 9 & $\begin{array}{l}\text { Under a new file: select choose } \\
\text { file and navigate to Get-Your- } \\
\text { financial-house-on-order.pdf }\end{array}$ & $\begin{array}{l}\text { The file should be uploaded and } \\
\text { its icon should be displayed }\end{array}$ & As Expected & Pass \\
\hline 10 & $\begin{array}{l}\text { Under file information, } \\
\text { Description, type "Financial } \\
\text { Fitness" }\end{array}$ & $\begin{array}{l}\text { Attachment description: } \\
\text { "Financial Fitness" should be } \\
\text { displayed. }\end{array}$ & As Expected & Pass \\
\hline 11 & Select Save & $\begin{array}{l}\text { success message should be } \\
\text { displayed and the user should be } \\
\text { redirected to newly created page }\end{array}$ & As Expected & Pass \\
\hline
\end{tabular}


Test Case 4 Images:

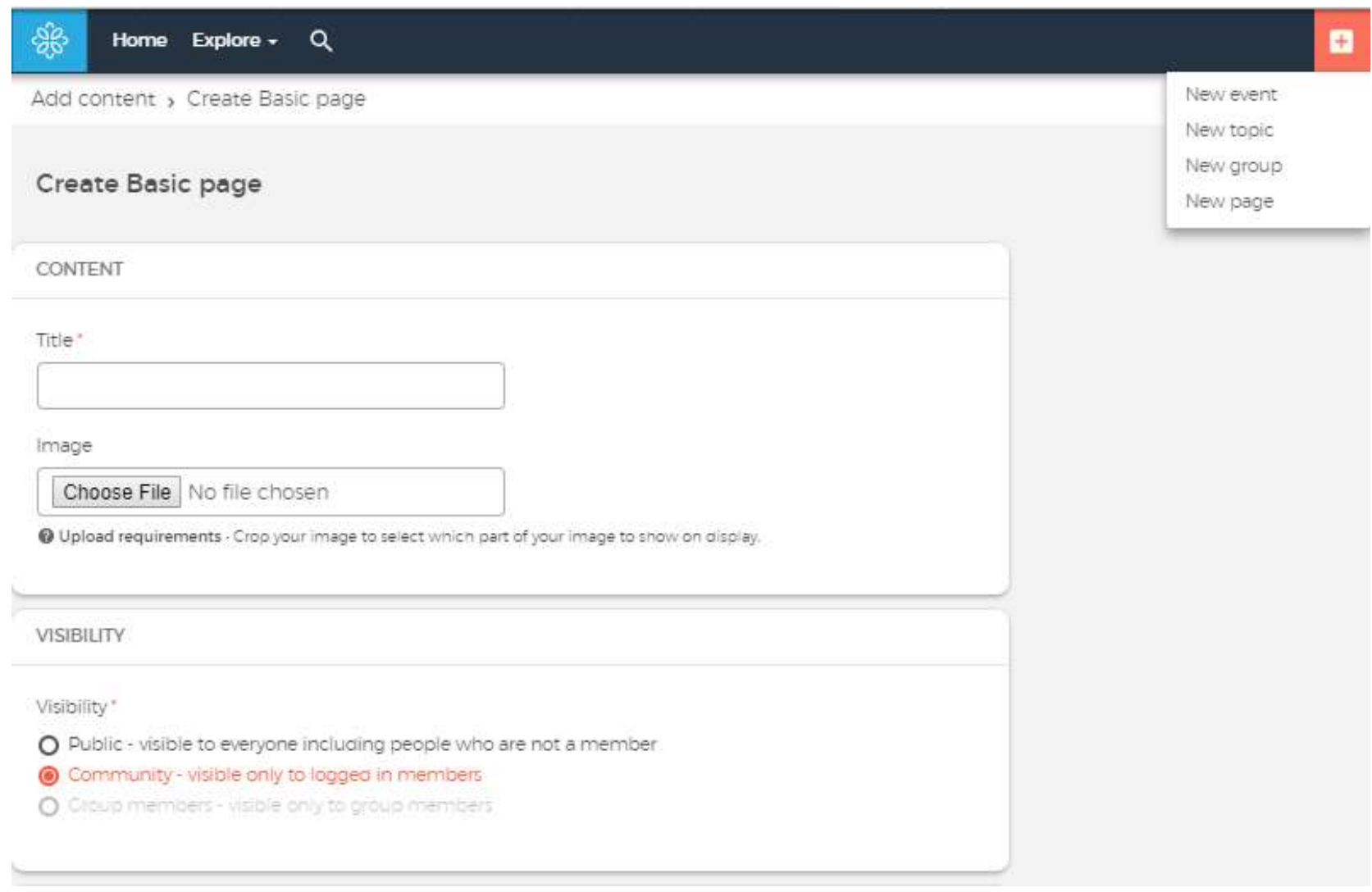




\section{VISIBILITY}

Visibility :

Public - visible to everyone including people who are not a member

C Community - visible only to logged in members

Oroup members - visible only to group members

\section{PACE DESCRIPTION}

Description *

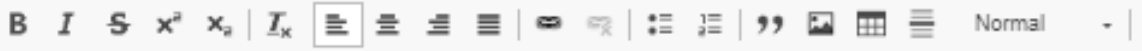

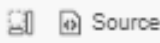

This is a page for sharing knowledge. knowledge is the new currency of a thriving economy.

body $\mathrm{p}$ 
The image was resized to fit within the maximum aliowed dimensions of

$4096 \times 4096$ pixels. The new dimensions of the resized image are $4096 \times 2304$ pixels.

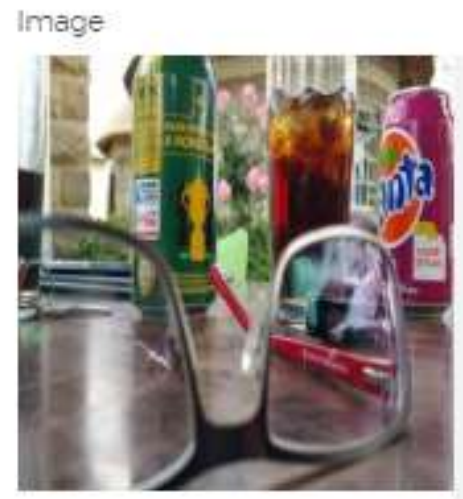

Aiternative text

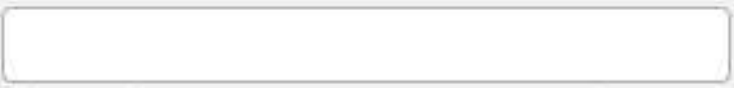

This text will be used by screen readers search engines, or when the image cannot be loadec
age
$2015-10-08$ 13.25.55.jpg
$141 \mathrm{MB}$

REMOVE

- CROP IMACE (CROPPINC APPLIED)

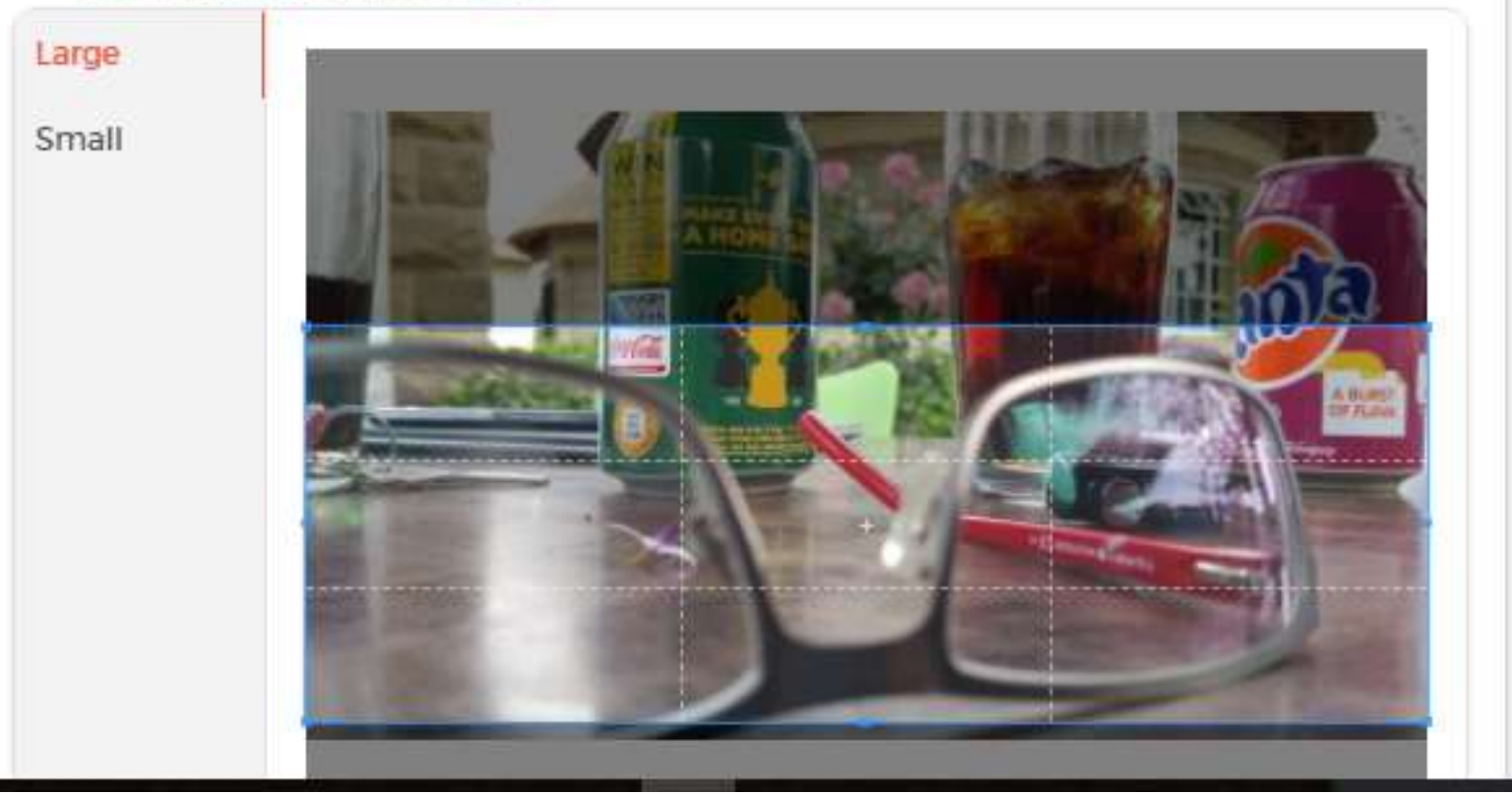




\section{ATTACHMENTS}

SHOW ROW WEICHTS

FILE INFORMATION

OPERATIONS

* Dat motivationtit $\quad 157 \mathrm{~KB}$ REMOVE

Description

Motivation|

The descriotion may oe used as the label of the link to the file.

4. To Cet-Your-Financial-House-in-Orderpat

LOB ME

REMOVE

Description

Financial fitness

The descriotion may oe used as the label of the link to the fie.

Add a new file

Choose Files No file chosen

(2) Upload requirements

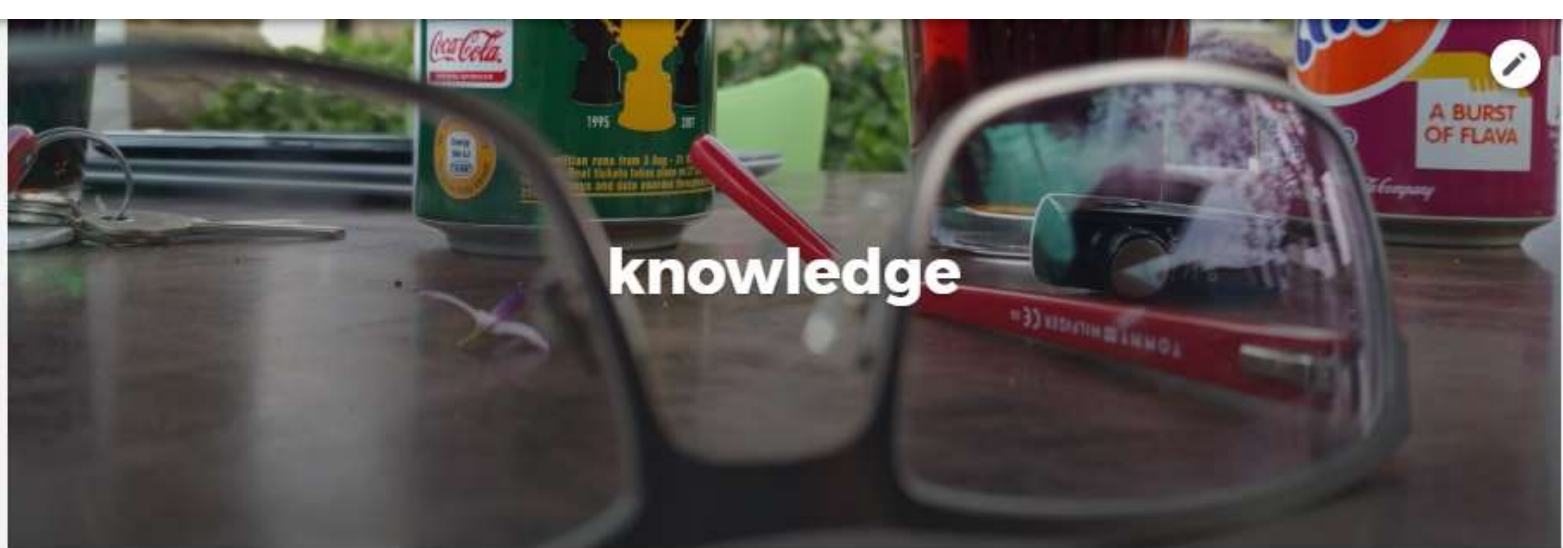

4. community

FOLLOW CONTENT

This is a page for sharing knowledge. knowledge is the new currency of a thriving economy

Files

Motivation Financial fitness 


\section{A.5 Test Case 5}

\begin{tabular}{|c|c|c|c|c|c|c|c|}
\hline \multirow{2}{*}{\multicolumn{2}{|c|}{$\begin{array}{l}\text { Test Case ID } \\
\text { Created By }\end{array}$}} & \multirow{2}{*}{$\begin{array}{l}\text { Tst_005 } \\
\text { Mafereka }\end{array}$} & \multirow{2}{*}{$\begin{array}{l}\text { Test Case Description } \\
\text { Reviewed By }\end{array}$} & \multicolumn{4}{|c|}{ Test Creation of Profile } \\
\hline & & & & \multicolumn{2}{|c|}{ Simon Winberg } & Version & 1.0 \\
\hline \multicolumn{8}{|c|}{ QA Tester's Log } \\
\hline \multicolumn{2}{|c|}{ Tester's Name } & Mafereka & Date Tested & \multicolumn{2}{|c|}{ June 2, 2018} & $\begin{array}{l}\text { Test Case (Pass/Fail/Not } \\
\text { Executed) }\end{array}$ & Pass \\
\hline S\# & \multicolumn{3}{|c|}{ Prerequisites: } & S \# & \multicolumn{3}{|c|}{ Test Data } \\
\hline 1 & \multicolumn{3}{|c|}{ Access to Chrome Browser } & 1 & \multicolumn{3}{|c|}{ First Name: Moeketsi, Surname: Mafereka } \\
\hline \multirow[t]{5}{*}{2} & \multicolumn{3}{|c|}{$\begin{array}{l}\text { Tester should have user name and } \\
\text { password }\end{array}$} & 2 & \multicolumn{3}{|c|}{ Image: passport size image } \\
\hline & & & & 3 & \multicolumn{3}{|c|}{ Function: Retail, Organization: Nedbank } \\
\hline & & & & 4 & \multicolumn{3}{|c|}{$\begin{array}{l}\text { Phone Number: } 0026658889488, \text { Country: Lesotho, Street } \\
\text { Address: P.O.Box 396, City: TY, Postal Code: } 200\end{array}$} \\
\hline & & & & 5 & \multicolumn{3}{|c|}{$\begin{array}{l}\text { Self-Introduction: "I like selling bank's products. Introducing } \\
\text { new value propositions." }\end{array}$} \\
\hline & & & & 6 & \multicolumn{3}{|c|}{$\begin{array}{l}\text { Expertise: Project Management Leadership, Interests: } \\
\text { knowledge management. }\end{array}$} \\
\hline
\end{tabular}

\footnotetext{
Test Verify that a profile is created successfully with the test data supplied

$\underline{\text { Scenario }}$
}

\begin{tabular}{|c|c|c|c|c|}
\hline Step \# & Step Details & Expected Results & Actual Results & $\begin{array}{c}\text { Pass / Fail / Not executed / } \\
\text { Suspended }\end{array}$ \\
\hline 1 & $\begin{array}{l}\text { Navigate to profile page } \\
\text { and select edit profile }\end{array}$ & $\begin{array}{l}\text { Edit profile page should } \\
\text { be displayed. }\end{array}$ & As Expected & Pass \\
\hline 2 & $\begin{array}{l}\text { Enter First Name and Last } \\
\text { Name as per test data. }\end{array}$ & $\begin{array}{l}\text { First Name and Last } \\
\text { Name should be } \\
\text { displayed. }\end{array}$ & As Expected & Pass \\
\hline 3 & $\begin{array}{l}\text { Browse for a passport size } \\
\text { image }\end{array}$ & $\begin{array}{l}\text { Selected image should be } \\
\text { displayed and ready for } \\
\text { cropping. }\end{array}$ & As Expected & Pass \\
\hline 4 & crop it to make it fit & Image should resize & As Expected & Pass \\
\hline 5 & $\begin{array}{l}\text { Enter Function, } \\
\text { organization, Phone } \\
\text { Number, Country, Street } \\
\text { address, City and Postal } \\
\text { Code as per test data. }\end{array}$ & $\begin{array}{l}\text { Function, organization, } \\
\text { Phone Number, Country, } \\
\text { Street address, City and } \\
\text { Postal Code information } \\
\text { should be displayed }\end{array}$ & As Expected & Pass \\
\hline 6 & $\begin{array}{l}\text { Enter Self introduction, } \\
\text { Expertise and interests as } \\
\text { per supplied test data. }\end{array}$ & $\begin{array}{l}\text { Self-introduction, } \\
\text { Expertise and interests } \\
\text { information should be } \\
\text { displayed. }\end{array}$ & As Expected & Pass \\
\hline 7 & Select Save & $\begin{array}{l}\text { Success message should } \\
\text { be displayed and the } \\
\text { profile page should be } \\
\text { updated with newly } \\
\text { entered information. }\end{array}$ & As Expected & Pass \\
\hline
\end{tabular}


Test Case 5 Images:

Account, Create Profile

\section{Edit Profile}

NAMES AND PROFILE IMAGE

First name

Moeketsi

Last name

\section{Mafereka}

Profie image

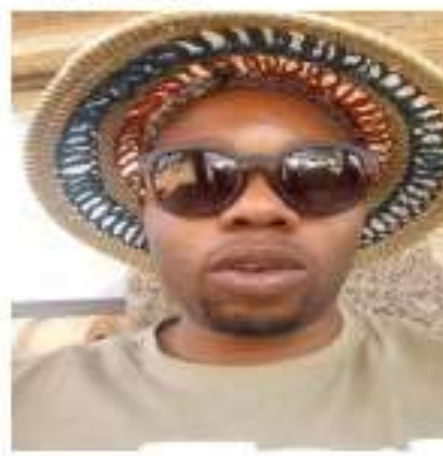

Alternative text

Moeketsi Mafereka

Thiz text will de used by ecreen readere search engines or when the image cannot oe looded.

Dim 2018-05-1215165tjog T/2MB

$\operatorname{sg}=$

REMOVE

- CROP IMACE ICROPPINC APPLIED)

Banner lmage

Choose File No file chosen

9 Upload requirements 


\section{SELF INTRODUCTION. EXPERTISE AND INTERESTS}

Self introduction

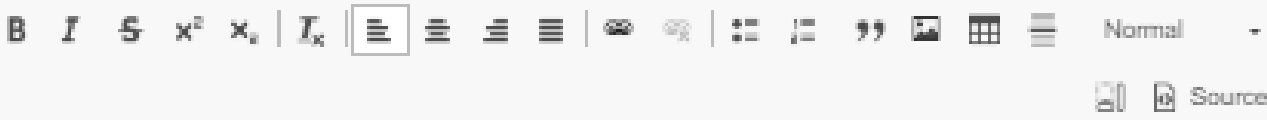

I like selling banks products. introducing new value propositions.

body $D$

Expertise

Project management, Leadership and

Seporate multiple values by o comme.

Interests

Knowledge management

Seporste multiple values by o comme. 
FUNCTION AND ORCANIZATION

Function

Retail

Organization

Neabank

PHONE NUMBER AND LOCATION

Phone number

0026658889488

Country

\begin{tabular}{|l|l|}
\hline Lesotho & V \\
\hline
\end{tabular}

Street address

P.O.Box 396

City Postal code

\begin{tabular}{lll}
\hline TY & 200 \\
\hline
\end{tabular} 
A. 6 Test Case 6

\begin{tabular}{|c|c|c|c|c|c|c|}
\hline \multirow{2}{*}{\multicolumn{2}{|c|}{$\begin{array}{l}\text { Test Case ID } \\
\text { Created By }\end{array}$}} & \multirow{2}{*}{$\begin{array}{l}\text { Test Case Description } \\
\text { Reviewed By }\end{array}$} & \multicolumn{4}{|c|}{ Test creation of new topic } \\
\hline & & & & & Version & 1.0 \\
\hline \multicolumn{7}{|c|}{ QA Tester's Log } \\
\hline \multicolumn{2}{|c|}{ Tester's Name } & Date Tested & \multicolumn{2}{|c|}{ June 2,2018} & $\begin{array}{l}\text { Test Case (Pass/Fail/Not } \\
\text { Executed) }\end{array}$ & Pass \\
\hline S \# & \multicolumn{2}{|l|}{ Prerequisites: } & S \# & \multicolumn{3}{|c|}{ Test Data } \\
\hline 1 & \multicolumn{2}{|l|}{ Access to Chrome Browser } & 1 & \multicolumn{3}{|c|}{ Type of topic: Blog } \\
\hline 2 & \multicolumn{2}{|c|}{$\begin{array}{l}\text { Tester should have user name and } \\
\text { password }\end{array}$} & 2 & \multicolumn{3}{|c|}{ Title of blog: "Block Test" } \\
\hline 3 & & & 3 & \multicolumn{3}{|c|}{ Image: blog image } \\
\hline \multirow[t]{3}{*}{4} & & & 4 & \multicolumn{3}{|c|}{$\begin{array}{l}\text { group: None, visibility: Community - visible only to logged } \\
\text { in members }\end{array}$} \\
\hline & & & 5 & \multicolumn{3}{|c|}{$\begin{array}{l}\text { Description: "This is my blog where we shall be sharing } \\
\text { content on music" }\end{array}$} \\
\hline & & & 5 & \multicolumn{3}{|c|}{ Attachments: None } \\
\hline
\end{tabular}

\begin{tabular}{|c|c|c|c|c|}
\hline$\underline{\text { Test }}$ & Verify that a new topic is $\mathrm{cr}$ & ted successfully with the test dat & supplied & \\
\hline Step \# & Step Details & Expected Results & Actual Results & $\begin{array}{l}\text { Pass / Fail / Not executed / } \\
\text { Suspended }\end{array}$ \\
\hline 1 & $\begin{array}{l}\text { Click icon to add new } \\
\text { content }\end{array}$ & $\begin{array}{l}\text { Dropdown for selecting content } \\
\text { should appear. }\end{array}$ & As Expected & Pass \\
\hline 2 & Select new topic & $\begin{array}{l}\text { page for creating new topic } \\
\text { should open }\end{array}$ & As Expected & Pass \\
\hline 3 & $\begin{array}{l}\text { Select type of content as } \\
\text { Blog and enter the title of } \\
\text { the topic as per supplied } \\
\text { test data. }\end{array}$ & $\begin{array}{l}\text { title of a new topic should be } \\
\text { displayed }\end{array}$ & As Expected & Pass \\
\hline 4 & Browse for a group image & $\begin{array}{l}\text { selected image should be } \\
\text { displayed and ready for } \\
\text { cropping }\end{array}$ & As Expected & Pass \\
\hline 5 & crop it to make it fit & Image should resize & As Expected & Pass \\
\hline 6 & Under Group: select None & "-None-" should be displayed. & As Expected & Pass \\
\hline 7 & $\begin{array}{l}\text { Under Visibility select: } \\
\text { community - visible only } \\
\text { to logged in members. }\end{array}$ & $\begin{array}{l}\text { "Community - visible only to } \\
\text { logged in members." should be } \\
\text { highlighted in red and a radio } \\
\text { button at the beginning of the } \\
\text { phrase. }\end{array}$ & As Expected & Pass \\
\hline & $\begin{array}{l}\text { Enter description of the } \\
\text { blog as per test data. }\end{array}$ & $\begin{array}{l}\text { Blog description should be } \\
\text { displayed. }\end{array}$ & As Expected & Pass \\
\hline 8 & & & & \\
\hline 9 & select save & $\begin{array}{l}\text { Success message should be } \\
\text { displayed and the user should } \\
\text { be redirected to newly created } \\
\text { group page. }\end{array}$ & As Expected & Pass \\
\hline
\end{tabular}


Images:

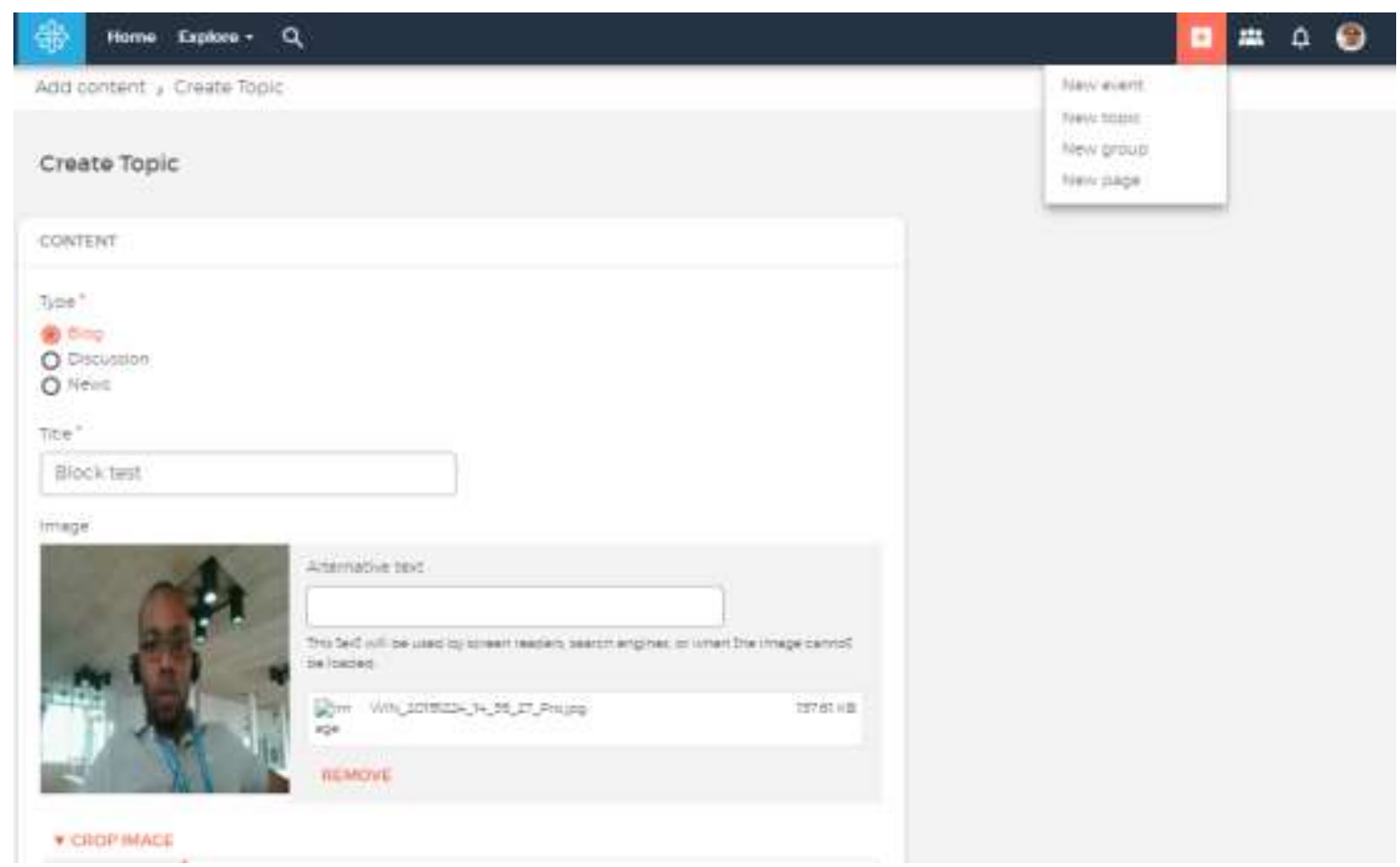

v CROP IMACE (CROPPINC APPLIED)

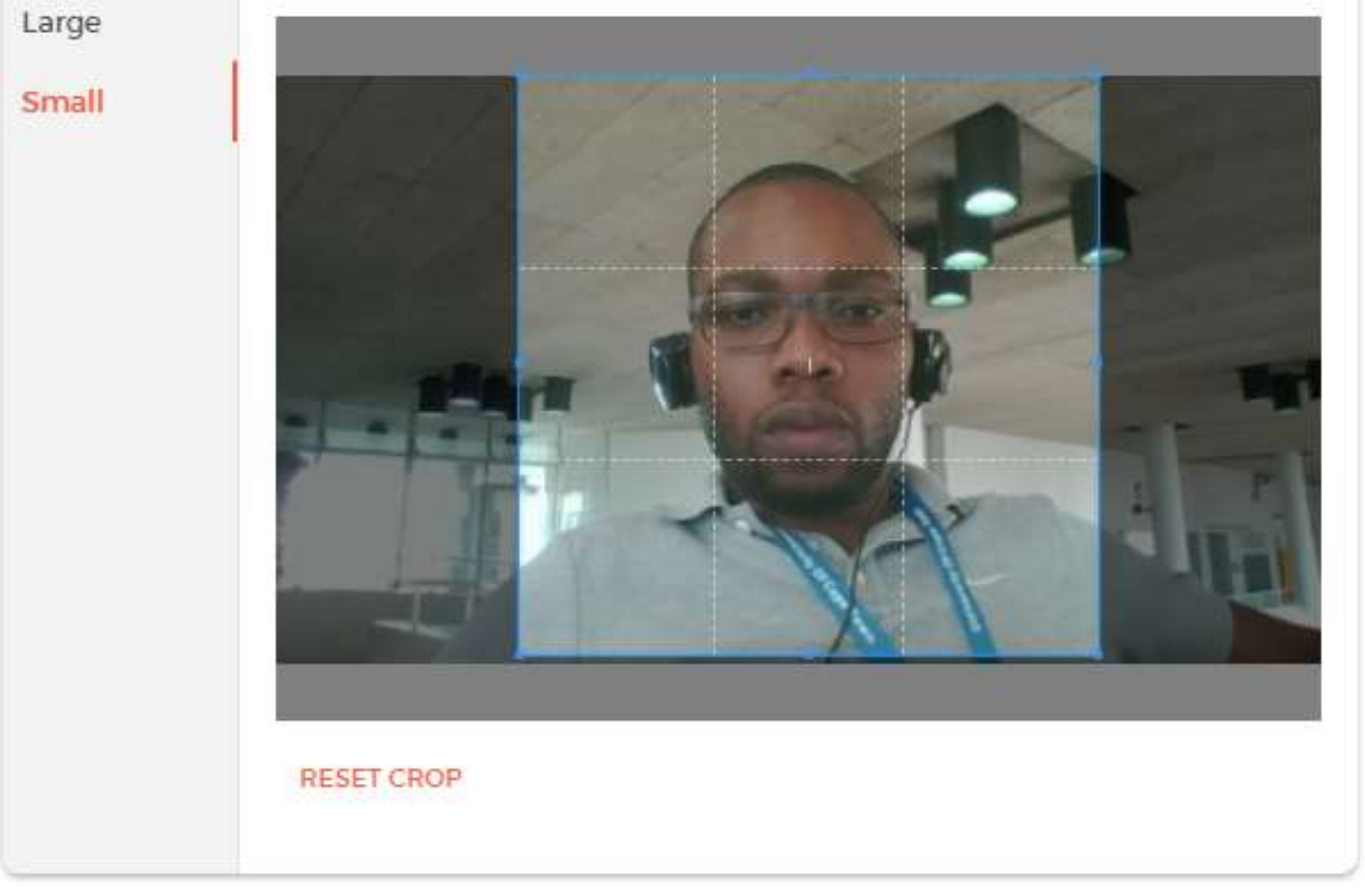

Crop your image to select which part of your image to show on display 
CROUP AND VISIBILITY

Group

- None - $\quad$ t

Visibility

Public - visible to everyone including people who are not a member

(C) Community - visible only to logged in members

Group members - visible only to group members

\section{DESCRIPTION}

Description *

B $I$ S $\quad x^{e} \quad x_{e} \mid \underline{T}_{x}$ 르 를 $\equiv$ dif Source

This is My blog where we shall be sharing content on music.|

body $\mathrm{p}$ 
ATTACHMENTS

Add a new file

Choose Files No file chosen

(2) upload requirements

Status

Last saved Not saved yet

Comment settings

Author mafereka

Revision information

No revision

URL path settings

No alias

Authoring information Authored on 2018-06-

19

Publish status

PREVIEW

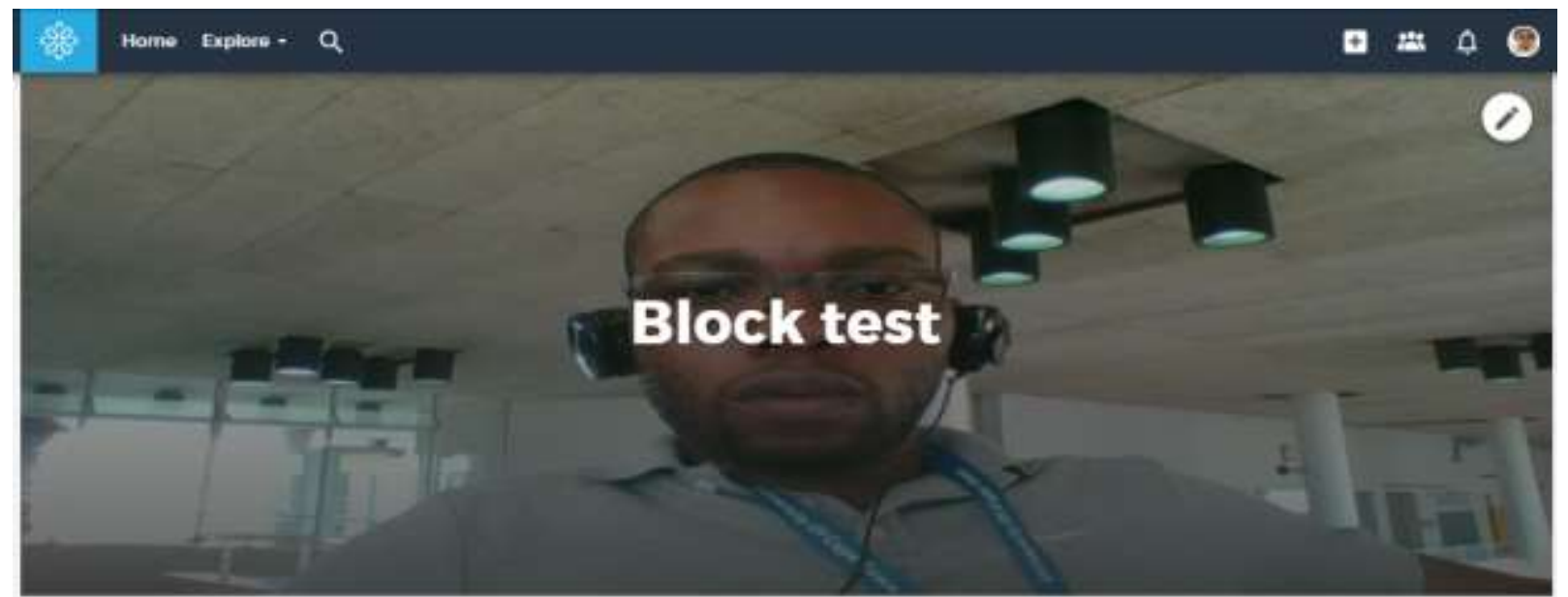

8

a Ocomments

- olies a community

FOUIOW CONTENT

This is My piog where we shall be sharing content on music

Oolikes 